\%)용 genealogy

Intergenerational

Traumaand

Healing

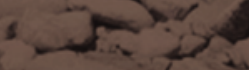

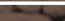

$\because$

Th - Edited by

Melissa Leal, Beth Rose.Middleton and Melissa Moreno Printed Edition of the Special Issue Published in Genealogy 


\section{Intergenerational Trauma and Healing}





\section{Intergenerational Trauma and Healing}

Editors

Melissa Leal

Beth Rose Middleton

Melissa Moreno

MDPI • Basel $\bullet$ Beijing $\bullet$ Wuhan $\bullet$ Barcelona $\bullet$ Belgrade $\bullet$ Manchester $\bullet$ Tokyo $\bullet$ Cluj $\bullet$ Tianjin

\section{MDPI}


Editors

$\begin{array}{lll}\text { Melissa Leal } & \text { Beth Rose Middleton } & \text { Melissa Moreno } \\ \text { Sierra College } & \text { University of California } & \text { Woodland Community College } \\ \text { USA } & \text { USA } & \text { USA }\end{array}$

Editorial Office

MDPI

St. Alban-Anlage 66

4052 Basel, Switzerland

This is a reprint of articles from the Special Issue published online in the open access journal Genealogy (ISSN 2313-5778) (available at: https://www.mdpi.com/journal/genealogy/special_ issues/intergenerational).

For citation purposes, cite each article independently as indicated on the article page online and as indicated below:

LastName, A.A.; LastName, B.B.; LastName, C.C. Article Title. Journal Name Year, Article Number, Page Range.

ISBN 978-3-03943-575-3 (Hbk)

ISBN 978-3-03943-576-0 (PDF)

Cover image courtesy of Melissa Leal.

(C) 2021 by the authors. Articles in this book are Open Access and distributed under the Creative Commons Attribution (CC BY) license, which allows users to download, copy and build upon published articles, as long as the author and publisher are properly credited, which ensures maximum dissemination and a wider impact of our publications.

The book as a whole is distributed by MDPI under the terms and conditions of the Creative Commons license CC BY-NC-ND. 


\section{Contents}

About the Editors $\ldots \ldots \ldots \ldots \ldots \ldots \ldots \ldots \ldots \ldots$ vii

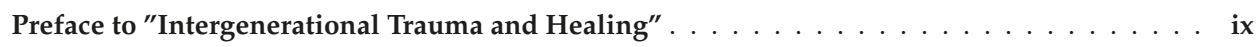

Luis Urrieta Jr.

Indigenous Reflections on Identity, Trauma, and Healing: Navigating Belonging and Power

Reprinted from: Genealogy 2019, 3, 26, doi:10.3390/genealogy3020026 . . . . . . . . . . . . . 1

\section{Mariia Lenherr}

Collective Trauma and Mystic Dreams in Zabuzhko's "The Museum of Abandoned Secrets"

Reprinted from: Genealogy 2019, 3, 4, doi:10.3390/genealogy3010004 . . . . . . . . . . . . 15

Rose Borunda and Amy Murray

The Wisdom of and Science behind Indigenous Cultural Practices

Reprinted from: Genealogy 2019, 3, 6, doi:10.3390/genealogy3010006 . . . . . . . . . . . . . 27

Bina Nir

Transgenerational Transmission of Holocaust Trauma and Its Expressions in Literature

Reprinted from: Genealogy 2018, 2, 49, doi:10.3390/genealogy2040049 . . . . . . . . . . . . . 37

\section{Roberto Rodriguez}

Fighting Law Enforcement Brutality While Living with Trauma in a World of Impunity

Reprinted from: Genealogy 2018, 2, 56, doi:10.3390/genealogy2040056 . . . . . . . . . . . . . 55

Barbara Erysian

Why the Armenian Genocide Lives in Me

Reprinted from: Genealogy 2018, 2, 50, doi:10.3390/genealogy2040050 . . . . . . . . . . . . . 61 



\section{About the Editors}

Melissa Leal, Ph.D. (Tribal Liaison), Tribal Liaison and Instructor of Social Science and Anthropology at Sierra College. Melissa's research centers on Native American contemporary art as language and cultural revitalization and California Indian education, film, and music studies. Her broader work implements equitable practices/programs for Indigenous students in California. She earned her BA in Ethnic Studies from California State University, Sacramento and a Ph.D. in Native American Studies from UC Davis.

Beth Rose Middleton, Ph.D. (Professor), Professor of Native American Studies at UC Davis. Beth Rose's research centers on Native environmental policy and Native activism for site protection using conservation tools. Her broader research interests include intergenerational trauma and healing, rural environmental justice, indigenous analysis of climate change, Afro-indigeneity, and qualitative GIS. Beth Rose received her BA in Nature and Culture from UC Davis and her Ph.D. in Environmental Science, Policy, and Management from UC Berkeley.

Melissa Moreno, Ph.D. (Professor) Professor of Ethnic Studies at Woodland Community College. Melissa's research centers on education, culture, and society; community-based knowledge production in social movements; and indigeneity discourse, practices, and leadership. Melissa received her BA in Sociology and Women's Studies from UC Santa Cruz and her M.Ed. and Ph.D. in Education, Culture, and Society from the University of Utah. 



\section{Preface to "Intergenerational Trauma and Healing"}

Intergenerational Trauma and Healing is a collection of writings by scholars and survivors of trauma. For many, the act of giving testimony about their own traumas is the healing piece. We invite you to explore this topic through the readings and use in your classrooms, research, and personal lives. Intergenerational trauma reaches far into communities who have experienced genocide and as you will read, even after the threat of violence is gone, our bodies remember. Our bodies also have the power and strength to heal. This text will explore how individuals and communities are healing, responding, and reacting. Through literature, personal story, and cultural practices, these authors share their research and possibilities for a well community

Melissa Leal, Beth Rose Middleton, Melissa Moreno

Editors 



\title{
Indigenous Reflections on Identity, Trauma, and Healing: Navigating Belonging and Power
}

\author{
Luis Urrieta, Jr. \\ College of Education, University of Texas at Austin, Austin, TX 78712, USA; Urrieta@austin.utexas.edu \\ Received: 11 April 2019; Accepted: 19 May 2019; Published: 25 May 2019
}

\begin{abstract}
Indigenous people are survivors of what some scholars have called the nexus of biopsycho-social-cultural-spiritual intergenerational trauma. The effects of these multi-plex traumas brought on by European colonialism(s) reverberate into the present and affect Indigenous peoples at various scales, from local interpersonal relations to larger macro scales of geo-regional displacement. Indigenous peoples, however, have also survived the traumas of displacement, genocide, racism, surveillance, and incarceration by sustaining systems of ancestral and contemporary healing practices that contribute to individual and collective survivance. In this essay, I explore intergenerational rememberings of Indigenous identity, trauma, and healing based on personal, family, and community memory. Through rememberings, I seek to deconstruct the Western constructs of identity and trauma, arguing that these conceptions create trappings based on the exclusions of membership that support power hierarchies that perpetuate the dehumanization of Native peoples. By exposing these trappings, I will engage in my own decolonizing healing process by reclaiming, reconnecting, rewriting and rerighting histories. Finally, through an I/We Indigenous philosophy of belonging, I will argue that emotion can be an important saber (knowing) to help understand Indigenous identities as connected, collective, and ancestral ways of knowing and being that re/humanize Indigenous collective relational understandings.
\end{abstract}

Keywords: survivance; sobrevivencia; healing; struggle; trauma; mothers; movements

\section{Breaking Silences}

Historical and intergenerational traumas are said to be the enduring legacies of colonialisms and their impact on Native and Indigenous communities. As Indigenous people, we are the survivors of what Beltrán and Begun (2014) have called the nexus of bio-psycho-social-cultural-spiritual intergenerational trauma. These traumas are the result of hundreds of years of colonialisms and enduring power structures that have impacted and continue to affect the lives of Native pueblos and communities. These multi-plex traumas brought on by European colonialisms reverberate into the present and touch Indigenous peoples lives at various scales, from local interpersonal relations to larger macro scales of geo-regional displacements that induce mass trans-regional migrations (Barillas Chon 2018). Such displacements are not new and they have ranged from the forced labor migrations of Indigenous peoples under colonial regimes, such as for mining or harvesting crops, to current global capitalisms' extractivist practices that forcibly remove communities from their ancestral lands by means of international mega-projects such as hydraulic fracking or hydroelectric plants (Urrieta 2016; Batz 2018).

Bringing historical and intergenerational trauma to the surface is a delicate issue and a doubleedged sword because often the violence experienced is hard to make sense of in simplistic ways and when simplified can be used to invoke homogenizing tropes of a collectivized Indigenous victimization and powerlessness (Kirmayer et al. 2014). It seems like intergenerational trauma has surfaced as I have been working on a book project tentatively titled Resurgent Indigeneities: Re/Making Indigena and 
Community through Education. The book is on Indigenous identity resurgence in Michoacán, Mexico, and is especially focused on a collective mothers' struggle for education that took place from 2005 to 2012. I began conducting the research for the book in 2006 and have been working on the book for at least the past five years. This project advances at snail speed, which often makes me wonder whether it is meant to be. Working on the book debilitates me because the responsibility I feel in writing it weighs heavily on me, me pesa como una carga. And it is not because my original enthusiasm for the research has waned. On the contrary, it has grown exponentially and my love for my ancestral community has swelled; but, working on this book weighs on my mind, body, and spirit. Why? I typically do not struggle with writing, but I cannot seem to move this project forward.

The violence, struggle and survivance I am attempting to write about in my work is complex, multilayered, multivocal and cacophonous (Byrd 2011) in my own mind and much harder to put out into the world on paper. The delicate musings about my portrayal of my pueblo and the mothers sometimes weigh heavily on me. Will this book ever see the light of day? Who will read it and why? What will they do with this information? That is still unknown, even to me. These resurfacing questions, which can also be called "academic dilemmas" for researchers of color and Indigenous scholars writing about their/our own communities, are precisely what weighs heavily on me. These dilemmas are ever present as I continue to read, engage, and write my study, the book, my family, my friends, compadres, comadres, and community into text. With each new conversation as well as each new archive, I confront the pain and joy of our pueblo's survivance (Vizenor 1999). However, the testimonios of sobrevivencia sustain, motivate, and heal me in the process. Trinidad Galván (2005, p. 11), drawing from Vizenor, defines sobrevivencia as survivance beyond responding to the global political economy to include everyday cherished interactions and measures. I have learned through the journeys that this research and book has taken me on that as Indigenous peoples, our individual and collective survivance and refusals of these so called traumas is immensely valuable and important. Although displacement, genocide, racism, surveillance, and incarceration continue, ancestral and contemporary healing practices that reconnect us also sustain and nourish us into our futures (Vega 2018).

This is not the first time I write about my ancestral pueblo-San Miguel Nocutzepo. What is the difference this time? The difference is that this work situates my ancestral pueblo at the center of an origin narrative and in the process, by default, it is also about my family and the people of my community, their ways of knowing and being that I now know more intimately. And yes, it is the intimacy that bears heavily on me and borders on the fear of betrayal, of breaking silences that are not meant to be broken, of re/opening wounds that are already seemingly healed. Part of the uneasiness in the book is rooted in the discomfort over writing about conflict in which there are at least two competing sides within layers of complexities. The mothers' movement I write about was violent in many ways and engaging the violence in a book brings out what some scholars have referred to as historical and intergenerational traumas (Duran and Duran 1995; Yellow Horse Brave Heart et al. 2011; Beltrán and Begun 2014; Garcia et al. 2018).

In this essay, I will explore intergenerational rememberings of Indigenous identity, trauma, and healing based on personal, family, community memory, and in part on politically engaged social research (Amigo 2019). Some of the memories and testimonios in this work emerge from my academic work on the book project. Others, however, have been part of my family's collective memory and have been passed down to me. Yet others I have lived myself as I have returned to Nocutzepo, instead of running away from it. Through rememberings, I seek to deconstruct the Western constructs of identity and trauma, arguing that these conceptions create trappings based on the exclusions of membership that support enduring power hierarchies that perpetuate the dehumanization of Native and Indigenous peoples through portrayals of suffering (Tuck and Yang 2014). By exposing these trappings, I will engage in my own decolonizing healing process as outlined by Smith (1999) by reclaiming, reconnecting, rewriting and rerighting histories. Finally, through an I/We Indigenous philosophy of Belonging in comunalidad, I will argue that emotion can be an important saber (knowing) 
to help understand Indigenous identities as connected, collective, and ancestral ways of knowing and being that re/humanize Indigenous collective relational understandings.

\section{Intergenerational Rememberings: El Pueblo}

San Miguel Nocutzepo is an ejido-based, P'urhépecha heritage pueblo of 939 people according to the 2010 census (INEGI). According to Vásquez Castillo (2004, p. 3), ejidos were tracts of communally owned land that were inalienable, nontransferable, and non-attachable and were, until 1992, on formal contract between the Mexican state and ejidatarios, the rural famers who owned them. Ejidos have historically been associated with Indigenous communal corporate land ownership. Located in the southwestern region of Lake Pátzcuaro, Nocutzepo is largely a Spanish speaking community. The pueblo is associated with indigeneity because of the racialized geography of the Lake Pátzcuaro Basin and because it has ejidos and maintains "usos y costumbres" (customs and traditions) traditionally associated with identifying Indigenous pueblos. When asked, the majority of the people of Nocutzepo do not identify as P'urhépecha due to language loss; however, some identify as indígena (Indigenous) and most recognize that they have P'orhé ancestors. Being Indigenous in this region has long been constructed as something negative due to the ongoing legacies of coloniality (Mignolo 2007), including of racism and exclusionary practices toward Indigenous people, and through the assimilation into mestizaje actively encouraged in Mexican schools (Dawson 2004). Internalized oppression, or taking on the identity of the oppressor and devaluing one's Indigenous culture and language, is also prevalent (Urrieta 2003).

The saliency of indigeneity in Nocutzepo, however, has varied at different recent historical periods. Groups that have at times embraced indigeneity in the community have not been consistent across temporalities. For example, many townspeople that opposed the mothers' Indigenous resurgence movement in 2005, were active proponents of Indigenous Instituto Nacional Indigenista (National Indigenist Institute, i.e., INI)-sponsored schooling in Nocutzepo in the late 1970s. In fact, when my father decided to return to Nocutzepo in 1976 after living in the U.S. for several years, I was enrolled for a brief period of time in the INI school where I first learned how to hold a pencil and to draw lines and circles on paper. I have fond memories of these early school learning experiences and was confused when my father abruptly stopped letting me attend the INI Indigenous school. When the short-lived school project closed, some community members went so far as to send their children away to Indigenous boarding schools after their efforts to maintain an INI school in Nocutzepo failed. Controversies over education before the 1970s, then, and now, like those with indigeneity, were frequently tied to political party alliances that led to very conflictive periods of violence, including my grandmother's death.

My paternal grandmother, Catalina Martinez or "Mamá Catita" died from a beating in 1978. While the Instituto Nacional Indigenista (INI) was created in 1948 to "assist" Indigenous communities in their process of acculturation through indigenismo (indigenism), the now defunct institution also became a political and, in some instances, corrupt bureaucracy, often pushing their own agendas (Hernández Castillo 2001; Saldívar 2018). Indigenismo, the INI's main ideology, as a state tenet and intellectual project for regulating Indigenous communities worked hand-in-hand with mestizaje and functioned not so much as a celebration of racial mixture, but as a state eugenicist program of racial whitening (Alberto 2016). According to Hernández Castillo (2001), Indigenous women's wombs became the epicenter of mestizaje. In the late 1970s, Nocutzepo erupted in conflict over the quality of education in the community in part due to INI intervention. The INI promoted their own schools in pueblos such as Nocutzepo by often pointing out the inequities of the federal schools for Indigenous peoples which further fueled the valid critiques some community members already had of the state schools. Some of the Nocutzepo parents' complaints of the school included that the teachers did not teach, that they physically beat the children, and that some male teachers showed up to work drunk or hungover. All of the teachers were not from Nocutzepo and nearly all of them were mestizo. 
Nocutzepo, with almost five hundred years of experience with colonialism, was divided in the 1970s over the issue of the school and over political party alliances and remains divided today over its Indigenous identity. Even though cultural shifts over the centuries diluted the strength of P'urhépecha identity in Nocutzepo, the pueblo was homogenized by the INI as having a collective Indigenous identity because indigenistas (indigenists) wrongly believed that Indigenous peoples belonged to ethnic groups (Hernández Castillo 2001). As mentioned, in Nocutzepo, not everyone identifies as Indigenous. Intergroup oppression, different degrees of internalized racism and self-hate, and socioeconomic differences exist and create rifts. The issue of indigeneity, demands to challenge the federal school, and support for the INI school all became local contentious issues. To be "more Indian" was generally equated with being poorer or darker by some, whereas mestizo was equated with owning more land, being better off economically, and having lighter skin. Indigeneity has also been associated with political party rivalries, which also appeal to voters based on socioeconomic issues. Mexican political parties often courted votes from the collectivized "campesinos" (peasants), who they also sometimes associated with being Indigenous since the post-revolutionary period (Boyer 2003) by making promises, providing food at events, or by giving families cash or despensas (groceries). These "gifts", sometimes also considered bribes, along with political alliances and campaigns focused on equity and resource redistribution (primarily land) tended to appeal to the poorer sectors of the electorate in the pueblo. Those with more land and wealth sometimes referred to as caciques (a Native chief, leader, or local political boss), often ironically ejido owners themselves within pueblos, tended to align together politically as well by disassociating themselves from being Indigenous, mostly to protect their economic interests, while perceiving those with less or no land to be more Indigenous; thus, essentializing and associating poverty with indigeneity (Hernández Castillo 2010). Although Indigenous communities are sometimes romanticized as homogenous and harmonious, socioeconomic inequities and conflict exist even within small pueblos like Nocutzepo. The heterogeneity of Indigenous pueblos thus only intensifies with such challenges; therefore, while some pueblo members embrace their genealogical indigeneity or Indigenous heritage, others because of intergroup oppression, or different degrees of internalized oppression, do not. In the 1970s, some townspeople supported the INI hoping for a better school for their children, but also seeking a redistribution of land, while others-accused of being caciques, sided against the INI. In the 1970s, Nocutzepo context mestizo meant less Indian, a complex and implicit claim to whiteness, but more of an active rejection of Indianness. While doing this research, I learned that my father did not support the INI and that is why he pulled me out of the school even though a lot of my cousins continued to attend.

Women were actively involved in the INI conflict, especially in voicing their support for the side they supported and, in the process, also engaging in verbal exchanges with their opponents. My grandmother, sad about the situation, took a bottle of holy water, prayed, and sprinkled it throughout the pueblo. She believed San Miguel Arcángel, the patron saint, would help drive Satan away. There is a legend in the pueblo that San Miguel dressed in his finest armor rides a white horse at night throughout the pueblo expelling all evil and protecting its people. My grandmother wanted the conflicts to end. Women that supported the INI believing she was casting an evil spell on them rounded up a crowd. Near the corner of a far, dusty street, she was surrounded and accused of witchcraft. Some of the women, about half her age, brutally beat her. That was where the story ended when I first wrote about it in 2003.

Initially, I led myself to believe that my grandmother was a victim, heir to colonial violence that divides and conquers, and I grieved with rage and anger for years. I guess I could have called that trauma; however, during my year doing research and living in Nocutzepo in 2009-2010, I found out that I was wrong. Yes, Mamá Catita was found lying on the ground by my aunts, Rosa and Leonor, who have now passed on to the next life, while several women laughed and spat at her, but my grandmother was not a passive victim. I came to learn that despite her age, she fought back that day because this was not the first time she had to defend herself. I was also told that in previous occasions, she never put her head down when confronted by some of the INI women at the communal molino (grinding 
mill) and that when she was slapped by one of the women once, her automatic survival instinct was to slap her back so hard that the woman immediately withdrew. She carried herself with a lot of dignity.

My grandmother's beating did lead to serious medical complications. When my father was informed that she was on her deathbed, he took a bus from Los Angeles to see her. Incoherent, claiming to be surrounded by angels, she died smiling in my father's arms. Her burial was poorly attended due to the town conflict. I remember the velorio (wake), the four tall candles, the praying, singing, and the last time I saw my grandmother. She was dressed in a red bayeta, a faja (waistband), multicolored huanengo (blouse), laced saco, and the traditional P'urhépecha black and blue rebozo. I held my maternal grandfather's hand as the coffin was lowered into mother earth, while women wailed loudly. I learned years later that expressing emotion and pain are not subdued in the face of grief but encouraged as a form of healing. A clay water jar, a bag of Mamá Catita's clothes, coins, and a clay dish with corn and beans were placed in the grave. My maternal grandfather said, "Para cuando llegue al otro mundo" - for when she arrives in the other world. As a child, I did not understand what I do now, especially by embarking on the journey of taking myself back to the pueblo, but I do remember the suffocating pain and being told to cry to let it out. And I know now why it was important that I be there as a child standing by the gravesite. During my research and time in Nocutzepo, I have been witness to numerous burials. They vary according to age, marital status, gender, and economic power, but there are always children present. Sometimes the children sit, sometimes they play, stand, or grieve depending on who is departing, but it is always a simultaneous lesson in loss, grief, and healing in preparation for life.

\section{Intergenerational Struggles-Las Madres}

In 2005, a group of mothers in Nocutzepo once again shared a growing concern for and subsequent clash over education with local school officials. This confrontation was not a new phenomenon but was reflective of the history of inter-community conflicts and violence and the generational neglect on the part of the educational system. Thus, the group of mothers that rebelled against the school by protesting their children's corporal punishment in early 2005, consciously or unconsciously, inherited some of their painful memories of schooling from past generations through local contentious practice (Holland and Lave 2001). The first government school in Nocutzepo, "Hogar y Patria," opened in 1922. It was amongst the earliest schools opened after the creation of the Secretaría de Educación Pública (SEP-Ministry of Education) was established in 1921. Throughout the 1920s, the school struggled with attendance and often threatened parents with legal action if they did not send their children to school. Between 1945 and 1951, the school was closed over students' absenteeism and lack of school personnel. During that time period, the local priest started a private school that only some children attended, until, in 1951, a public school reopened for all school-aged children in Nocutzepo under the name of "Narciso Mendoza". Eventually, years later, the school would be renamed Escuela Primaria Benito Juárez. While some community members recalled having very positive schooling experiences, some of the mothers I interviewed in 2010 recalled that as little girls they had their hair pulled right above their ears, as well as their hands hit with the peeled branch of a peach tree by some of the teachers when they did not answer correctly. Some recalled being humiliated by some of the teachers by being called tontas or mensas (dumb) and cochinas (dirty).

Like the Nocutzepo mothers of the 1970s, the mothers in 2005 asked for better teachers, the overall improvement of their children's education, and a safe bathroom instead of a latrine with rotting wood boards. They demanded an end to corporal punishment, they wanted evidence of learning, and in particular for a male teacher to stop showing up inebriated or hungover to work. It is important to note that the teachers at the school have never been from the pueblo, they have always come in to teach from elsewhere. The mothers' repeated requests for changes were systematically ignored and dismissed by the school principal, so they demanded her resignation. Some mothers reported that the school administrators laughed in their faces and asked them sarcastically, "Why do you want better teachers if your children will never amount to more than macuarros (construction workers)?!" When 
they sought out local and state education officials beyond the school, they were not well received either, if they were received at all. These forms of violence increasingly frustrated and angered the mothers, but also ignited in them a desire to organize and struggle for what they thought was right.

In response to the abject humiliation they experienced, the mothers gathered during the summer vacation and carefully planned a plantón (takeover of the school) that they executed on the eve of 24 August 2005, and that impeded the start of the new school year. They blocked off the entrance to the school with a colectivo (local bus) that one of the fathers drove, and they hung mantas (cloth banners) with written demands that the school principal immediately resign. Seeking out a larger public forum, some mothers were driven to Morelia the state capital by one of the fathers and they presented their demands along with 51 signatures in their support to one of the largest newspapers in the state, La Jornada Michoacán. The mothers and their supporters orchestrated a successful plantón but would have a long road ahead in terms of struggle to be heard. While they occupied the building, they organized watch guards, cooking teams, and met and thought about strategies to move their struggle forward. Together, they recognized whose strengths were needed where and they co-labored to maintain their focus on their demands. After weeks of holding the school building hostage, the women were brutally attacked by their opposition, both community members that did not support their efforts as well as by some of the school personnel, in an effort to end the plantón. Through physical violence, including by men, the mothers were literally pushed or dragged out of the school building. Some sustained serious injuries and needed medical attention. However, the mothers, like my grandmother, were not passive. They too fought back, including against men. One mother proudly recounted to me how she was slapped by the male teacher often accused of showing up to work drunk and who had yanked her son's earring off, and how she just attacked him back. She said she could not recall exactly what happened, but when they were finally pulled apart, she had a bunch of his hair in her hand covered in his blood.

As in many women-led movements throughout Latin America, the mothers' struggle continued even after they were disbanded and physically beaten (Stephen 1997; Hernández Castillo 2010). Trying several alternatives, the mothers were eventually left with very few viable long-term solutions. Despite their continued organizing and lobbying, federal rural education policies did not allow for the creation of another school in such a small pueblo. Finally, the mothers resorted to soliciting an intercultural Indigenous education program in the neighboring pueblo of Arócutin, recognizing (or confronting) their Indigenous ancestry. The mothers and families involved received support by a male local school administrator for a bilingual intercultural (P'urhépecha/Spanish) "satellite" campus as an extension of the Indigenous school in neighboring, Arócutin. Nueva Creación (New Creation), the new physically precarious school made out of scrap metal and other improvised materials, opened in 2007 with his support, but its creation led to continuing and ongoing conflicts within Nocutzepo over having two elementary schools. For some pueblo members, re/turning to an Indigenous identity or to bilingual intercultural Indigenous education was considered a negative regression away from the modernity of progress and development. Such rhetoric contributes to the erasure of indigeneity by casting it as backward, old fashioned, rural, and expired (Hernández Castillo 2010). In the midst of narco-cartel violence and with increasingly less land and less agriculture due to ejido privatization and a booming avocado industry actively seeking to expand production (Maldonado Aranda 2013), for others, Nueva Creación was an avenue to recuperate a "lost" heritage and prior notions of "a good life" (sesï irekua). Most important, to the mothers, Nueva Creación represented an avenue to ensure that their children would have a safer, perhaps more viable education option in the face of dwindling economic opportunities. Nueva Creación eventually became a symbol of resistance to the educational neglect by the government, external deficit perspectives of the community, and the encroachment of redefined local agro-export economies. The school was eventually officially authorized after years of lobbying in February of 2012 and Nueva Creación was renamed Curicaveri, in honor of the P'urhépecha deity of fire. 
I must reiterate that the mothers' Indigenous identity resurgence is not coincidental. The mothers did not one day decide to become Indigenous women. Indigeneity in and around Nocutzepo, despite the language shift, has always existed in different ways and forms. The processes of cultural change did not completely erase the connection and memory of indigeneity that allowed the mothers to re/claim an indigena identity. The rekindling of indigena identity in the mothers' struggle is therefore complex, multiyared, multivocal, painful, cacophonous, contradicting and healing, as are Indigenous identities in general (Cadena and Orin 2007; Martínez Novo 2006). Perhaps the resurgence in Indigenous identity is an outcome and not necessarily the genesis of the mothers' struggle? Perhaps it is both?

The Nueva Creacion/Curicaveri mothers, however, did claim indígena as an identity and that is significant because it raises important questions: While the mothers' response to the educational neglect in their children's school can be seen as an example of how collective agency transformed a historically contentious practice [tense relations with the school] and enduring struggle (Holland and Lave 2001), is it also the basis for Indigenous identity resurgence in this "de-indianized" community? How is this struggle for education reflective of Indigenous community-based forms of sobrevivencia in a colonial context of neoliberal dislocation? Specifically, how and why does this reclaimed indigena (Indigenous) identity disrupt state structural constructions of officialized indigeneity through mestizaje?

In answering these questions, I develop the insights the Nocutzepo mothers' movement contributes to, (1) changing claims of indigeneity, (2) to emerging forms of agency (Ortner 2006), (3) to the importance of sobrevivencia in rural neoliberal Mexican agricultural communities even in the increasing absence of ejido-based subsistence agriculture, and (4) the role of intercultural education in rekindling comunalidad as a basis for indigeneity. Nocutzepo mothers' demands for better schooling through bilingual intercultural Indigenous education, based eventually on their claims to indígena, while simultaneously framed within neoliberal discursive formations of choice and opportunity in education, do challenge and disrupt state structural definitions of who is indigena, and upset Indian/non-Indian dichotomies entertained by social scientists and indigenists by creating an alternative space for indigeneity. While mestizaje in Mexico has always been perceived as a de-indianization process, an escape out of Indianess and a claim to Hispanic-ness or whiteness (Alberto 2016), the Nocutzepo Nueva Creación/Curicaveri mothers have reversed this to claim indigena.

Usually based on native language fluency and traditional attire, state officialized indigeneity would exclude the Nocutzepo mothers from being Indigenous because they do not speak P'urhépecha, nor, do they, for the most part, dress in traditional attire. Yet the mothers' claim to indigena as ancestral and genealogical while contemporarily marked primarily through their children's bilingual intercultural schooling in Nueva Creación/Curicaveri is significant for alternative constructions of indigeneity because it raises questions about Indigenous collective rights claims in the neoliberal multicultural state (Hale 2004). Namely, how does the current neoliberal context of displacement through land dispossession, narco-cartel violence, and precarity, such as what Nocutzepo has experienced, encourage changing notions of indigeneity? What do these new forms of indigeneity mean?

From a larger perspective, for the mothers, rather than being absorbed and erased through the nationalist assimilationist practices of the liberal state, they developed a multi-layered, multivocal, cacophonous, contradicting and healing discourse of indigeneity, that allows them to exist as indígenas and to enjoy some of the benefits of neoliberal multiculturalism, even without official sanction. Particularly in education, for the mothers and families involved in this struggle, it eventually meant finding for their children an alternative schooling and path to the few viable opportunities available to them in the local context of an agricultural community increasingly without agriculture, with a growing youth drug culture and local low scale drug economy, and with few local low paying jobs. An education through bilingual intercultural Indigenous schooling would allow them, in theory, access to coveted opportunities created by the state (ironically) to access higher education, including the local Indigenous teachers' college (la Normal Indígena) and Indigenous polytechnic institute in Cherán K'eri, or the Indigenous intercultural university system (Universidad Intercultural Indígena de Michoacán-UIIM), with open enrollments and free tuition for Indigenous students. 
Agency, through the mothers' resistance, also became an important basis for alternative constructions of indígena identity because P'urhépecha identity still remained inaccessible to them due to language loss, and mestiza was not Indian enough to merit intercultural bilingual schooling. The mothers' resurgent, and perhaps maybe even "generic", third space or nepantla (Anzaldúa 1987) indigena identity, although controversial and maybe even problematic to traditional notions of Indigenous authenticity, by that I mean those notions of Indigenous authenticity policed by Native communities themselves, or even harmful to communities with stronger usos y costumbres, does however also challenge the discourse of the incorporated (disappearing) Indian by existing outside of the state sanctioned definitions of indigeneity (Urrieta 2017). Sobrevivencia, including strengthening communality and community control over institutions like schools especially through women-led initiatives, afforded the Nocutzepo mothers rights claims and opportunities, like the Curicaveri school, as a step toward remedying intergenerational educational neglect, and by providing another educational outlet for their children. Most importantly, the Curicaveri bilingual intercultural community school, strengthened by a sense of collective struggle, played an important role in rekindling comunalidad (communality) as a basis for indigeneity (Aquino-Moreshi 2013; Rendón Monzón 2003) for the mothers, fathers, grandparents, and their children. This space of comunalidad focused on collective co-labor (faena) to build and support the school, with local community knowledge as a basis for learning, and community memory, ceremony, and celebration as a basis for indígena identity resurgence.

Despite the noteworthy accomplishments for the mothers' struggle, I also do not wish to romanticize their story, and so I want to conclude this section with some important critical questions: how did the eventual concession by local authorities to authorize Curicaveri divert attention away from larger struggles of oppression? How did the concession of the Curicaveri school clave (permit) in 2012 minimize the potential for larger unified Indigenous struggles against neoliberal dislocations? How did the victory that Curicaveri represented to the mothers also "fix" discourses, identities, and people into regimes of governance (Speed 2005)? Today, in 2019, the Nocutzepo community still struggles with having two elementary schools with inadequate facilities. Benito Juarez, the original school and point of conflict in 2005, finally built new bathrooms in June of 2016, while Curicaveri's metal sheet walls were blown away by a strong whirlwind on 14 March 2015. The school has since been rebuilt by the families and the municipal government has built them bathrooms as well. The student population at Curicaveri, however, declines each year with each graduating class. La cultura cuesta. Culture is expensive and most families do not have the financial means required to sustain the schools' programs.

\section{Researcher Reflections on Identity and Healing: Luisillo el hijo del Chato}

I previously wrote an essay in which I was trying to makes sense of my identity as a person born and raised in urban Los Angeles, of Mexican undocumented immigrant parents, a descendant of a P'urhépecha pueblo, juggling between two languages, English and Spanish, but not speaking P'urhépecha, the language that I felt I should speak. In some ways, I was feeling cornered by the pressure of U.S. racism and identity politics to choose a rational label, in the Western sense. One to stake out a positionality, a social location. Too scared to pick up the fragments of what I thought was left of my past and culture(s) and too hurt to not speak about pain, confusion, and anguish, I searched for a way to work through these feelings and emotions and I wrote about my life, my family and my past. I wrote about my life because it was the story I knew best. I suffered because I felt the wounds of colonization from the dis-member-ment of my past, the confusion of that present, and literally from death; the death of my grandmother in community struggle.

As I worked through my reasoning, but most importantly through what I fixated on as trauma and pain, I came to the conclusion that all identity labels were inadequate for me. I wrote the following (Urrieta 2003, p. 148): 
The reality is that identities are painful, contradictory, emotional, re/colonizing, endlessly searching is seas of everything and nothingness, simultaneously. Identities sometimes do not have a word to describe them: sometimes identities cannot be explained, and in the attempt at explanation, identities also cry.

Indeed, I cried-and sometimes I still do. I was mourning. I was mourning what I thought were losses that could not be recuperated and failing to see what I did and do have. My grandmother could not be brought back to life, but she is not gone. What I failed to see then was how she lives in us and I also did not see the example of fighting back and dignity that she left for us.

As I engaged in my own decolonization process as outlined by Smith (1999) by reclaiming, reconnecting, rewriting and rerighting our his-, her-, and they-stories, I encountered the silences of my schooling. In retrospect, I felt the violence of schooling as a stripping of my body-that is not just a body, but a living collective archive of both colonialist violence and Native resistance, Indigenous survivance and resurgence. Romanticizing my P'urhépecha past, though, I lamented what was done through colonization and realized that the evils unleashed could not be undone. Through reclaiming, however, I also realized that the processes of colonization are not complete, they never were. Our survival is testament to its incompleteness even though the structures in place continuously attempt to advance the colonialist cause.

In August of 2009, I returned to my ancestral pueblo San Miguel Nocutzepo with the financial support of a Fulbright fellowship. I left with the blessing of the U.S. Department of State, on leave from my university job, and with a visa that allowed me to stay in Mexico beyond three months as a US citizen. I explicitly make it a point to highlight my privileged circumstances, not out of arrogance, but to signal the irony of my family's situation then as a mixed legal-status family because, despite these circumstances, we were not immune to the rigid US immigration laws that stubbornly deem some "illegal," criminal, and deserving of punishment. My family and I left the U.S. together to stay together. Immigration and Customs Enforcement (ICE) together with the National Visa Center (NVC) required that our family be separated. Once again, the raja, the open wound, the U.S.-Mexico border that Anzaldúa (1987) so aptly wrote about was tearing our family apart. Even though the Fulbright was a prestigious award, it was not the prestige that I sought, but a way to leave the country together with my spouse and children. It had a completely different meaning for me/us that had little to do with prestige. It led me/us to el tupu (bellybutton), where life begins and where it ends-our ancestral home, el pueblo. The fellowship became another bandage to cover up a wound. A wound inflicted by the fact that national borders and immigration laws dictate exclusions, expulsions, and "authorize" us as people. In this case, my spouse was being banished, even though I am a U.S. citizen, and our children ( 3,5 and 6 years old at that time) were supposed to be the "hardship". I was to plead to NVC to bring her back "home." Instead, we all crossed beyond the raja that separates, divides, cuts, and kills, together.

The blessing/healing part of this story was my/our return home-al pueblo, the place where all of my/our known grandparents are buried. The return was and was not easy. I am a known person, Luisillo el hijo del Chato, but I had also never lived there for longer than a few months as a grown man. Inevitably, I made mistakes and did not always fulfill people's expectations, but I also made lifelong friendships and reconnected with the land, our home, and our people. As a researcher, I must admit I was also confused. At times, I felt lost. This was due to me being an academic, being someone who otherwise lives in the U.S., and holds citizenship here. I realized that all of those things created barriers for me as an Indigenous person and created distance between me and my ancestral community of origin and yet, at the same time, this ability to migrate back remained key to re-immerse myself in a particular place, to engage in, and re/learn the particular communal worldview of my pueblo. I saw this as an opportunity with the potential to disrupt some of the colonial apparatuses at work in my life and in both the U.S. and Mexico. At that point, I decided to let all my guards down and fully immerse myself in Nocutzepo's life first as a person, family and community member-then as a researcher. I learned a lot. I learned what it means to live in la comunidad and my life has not been the same since. 
In 2010, when asked to reflect on my 2003 essay as a contribution to a collective volume on hemispheric indigeneity (Castellanos et al. 2012), I wrote the following (Urrieta 2012, pp. 332-33):

The streets have been paved in Nocutzepo and under the pavement were buried the memories of past decades. Although the past is being relived in recent pueblo conflicts over indigenous identity once again, no one remembers my grandmother as much as my 82 year old, unwed, aunt who wonders why she was left alone to live this long. Nocutzepo has grown and some things have changed, and yet others have not.

In Nocutzepo I learned that I was wrong, my grandmother was not a passive victim. I was told that despite her age she fought back on that fateful day. In la comunidad I had to interact with my grandmothers' aggressors because living in comunidad means to live together, in communion. Comunidad does not translate to community, it's more than that-it has no translation. I am no longer angry, I've learned to forgive; my spirit rests. The women who beat my grandmother are now old and sick. I see them with compassion rather than hate. The heavy load of their age seems like a debilitating burden, they are the elders now.

Through my research I've discovered that Nocutzepo is at least almost 500 years old, yet la comunidad is dynamic, it lives. Indigenous cultures are not just traditional dress or rituals, but every-day interactions and ways of being, usos y costumbres, that also change with time. In 2005 the pueblo was once again shaken with unrest, resulting in violence and separation-thankfully no one was killed this time. Ironically, the children (now adults) of those who in the 1970s wanted to distance themselves from being indigenous are now trying to rescue P'urhépecha cultural traditions through education. A new elementary school, bilingual and intercultural, was built as a cultural rescue project after intense fighting and struggle. The enthusiasm for re/learning the $\mathrm{P}^{\prime}$ urhépecha language and cultural practices by this new generation is contagious. And even for those who oppose the new re/turn to indigenous identities, the hope is that with two elementary schools in la comunidad, one indigenous and one federal, the quality of the education for all of the children will improve.

These struggles and conflicts over the years show that the community and its identities are alive and dynamic. Community conflicts are not necessarily bad; they show that people are passionate and willing to fight for what they believe in. My grandmothers' death was not in vain. She lives in us, her descendants, and in the community itself. I see her in my daughters' profound and innocent black eyes. I've felt her presence walking down Nocutzepo's dark streets at night. Identities cry, yes indeed, but they also laugh, they joke, they are alive in all of their complexities and full of sentient resources that often go unaccounted for (Castellanos 2009).

Decolonization, or this search for self, is painful. I learned about decolonization by living en la comunidad in ways that I would have never been able to had I not lived there. Nocutzepo's life and vitality, as a comunidad, despite the violence and conflicts, is itself a decolonial project. It is like a wild horse that refuses to be tamed; a horse that wants to ride freely with the wind in those beautiful landscapes. La comunidad's survival, despite continuous attempts to subdue it, is amazing. Knowing more of the history of Nocutzepo and the many different institutions that have tried to change it and to intervene in it, mostly from a cultural deficit perspective, over the decades, is also eye-opening.

It was not always easy to live there because I was not a neutral, unnoticed observer. I entered Nocutzepo, not only with my own personal history, but also carrying my family's generational history. Some experiences were hard to take; others will be like small jewels that I will value for the rest of my life. The overall experience was priceless. Decolonization is painful, but it's a necessary and enduring process toward healing that we must continue to fight for, not only for ourselves, but for future generations. Indigenous identities continue to cry, but they also laugh, they make love, they fight, they hope, they endure, they procreate, they live-we live. Our ancestors live in us, and we will live in our children. 
Through this re/learning in la comunidad, I learned that my relations to others, not just humans, but also the non-living is an I/We and not an I/You relationship. Indeed, the individual in Nocutzepo did not exist outside of a larger family and community structure that did not just involve the living, but also the dead. People actively engaged in the co-labor of being a family member because these were/are not just honorific titles, but relations that require the work of being (Urrieta 2013). Comunalidad is key to community sobrevivencia in Nocutzepo because, despite the divisions, people must come together for the collective good of the pueblo. Nocutzepo maintains contemporary community service practices known as faenas from previous Indigenous institutions of collective community labor, or co-labor. Some forms of temporary and permanent collective services include rotating co-labor to benefit church maintenance and other civic or religious organizations through cargos or encabezados; through collected monies to pay for fiestas (cinación) such as San Miguel feast, Christmas, and Corpus Christi; and required collective labor for pueblo improvements and repairs, including churches, streets, water, and collective land maintenance amongst others. At these moments of coming together, people must overcome their differences, even their hate, put it aside and work side-by-side for the collective good of the pueblo. With few exceptions, unless physically unable because of illness or old age, all (women, men, and children) must be present whether it is for work or for a pueblo fiesta. That is the reason why so many people in diaspora who are able feel compelled to go to such great lengths to return home to their pueblos with their children for fiestas each year, to collectively recognize, to reconnect, and to heal with their pueblo (Urrieta and Martínez 2011).

\section{Decolonizing Identity and Trauma with I/We Belonging and Healing}

Finally, as a P'urhépecha and an academic, I want to revisit and critique the concept of identity as a Western notion centered on self-awareness and individualism. The Western relational aspect of identity often centers on the contrast between Self/Other; the Self often implying the Western center, while the subaltern usually the marginal Other (Sarup 1996). Identity work, when studying the Other as an academic enterprise as is often done with Indigenous peoples, is often thus devoid not only of human bodies but, more importantly, of human emotions and human lives because it has been built on subject formation based on exclusion and power (Urrieta 2003). In our recent edited book Cultural Constructions of Identity, we, Urrieta and Noblit (2018) conclude that the construction of identity as always premised on exclusion, what one is not, is therefore a Euro-Western set-up, an en-"trap"-ment for the maintenance of power hierarchies and the preservation of whatever is constructed as normative (i.e., mestizo, ladino, white supremacy, etc.). These trappings we argue are usually framed as either/or propositions and binaries such as Indian/Non-Indian, Native/Not-Native, that create exclusion of memberships, power hierarchies, inter-community violence, and the dehumanization of Native peoples based on notions of authenticity, often influenced by state regulation such as blood quantum, or requiring native language fluency for example. Intersectional analyses of identity, we propose, although they reveal more of the power hierarchies and name and critique the normative and other privileged "isms" in the backdrop in an effort to unbind the traps of dualistic identity constructs, is still partial. Indigeneity, as seen in the Nocutzepo mothers' struggle is much more complex, dynamic, resistant, and multivocal than either/or constructions or intersections. Indigeneity must therefore be understood at multiple scales in its own terms, times, places, and temporalities. While there are general understandings of Indigeneity, there are also particularities that need to be accounted for within their own onto-epistemic cosmovisions that "identity" can only partially account for.

Similarly, in terms of historical and intergenerational trauma, Kirmayer et al. (2014) invite us to rethink the psychological and psychiatric constructs these forms of collectivized and conflated experience are based on and their impact for Indigenous peoples. They point to the particularities of structural violence and the varied impact and outcomes of colonialism on the diversity of Native and Indigenous experiences, especially the ongoing undermining of Indigenous autonomy, the expropriation of lands and resources through extractivist capitalisms, and the enormous economic disparities that exists even amongst Indigenous groups to highlight why a construct of historical 
trauma collectivized and essentialized to all Native and Indigenous peoples and often compared to the Holocaust can be problematic. Most importantly, why the strong focus on trauma as an explanation for current social inequities and their consequences can reify victimization, deficit, and pathologizing views of Indigenous ways of knowing, being and doing. In response to debilitating constructs based on trauma, Vega (2018) refusal of trauma by not naming her father, whom she reconnects with after a long absence, as an "alcoholic" is a great example of the recognition of pain/healing that is possible in relational ways, but also of the conscious rejection of the pathologizing nature of "trauma" that is often necessarily bred into disciplinary psychology and psychiatry constructs that are based on diagnosis and medicalization, even with the best intentions. While recognizing that colonialisms brought on historical violence and structures of violence that prevail, this must not be the only way we can understand and explain Native and Indigenous life. While recognizing the violence in the Nocutzepo mothers' movement and in my own family's experience with my grandmother, theirs is not just a story of pain (physical and emotional) and struggle, but also a story of strength, dignity, women-led organizing, co-laboring, alliances, reclaiming, and sobrevivencia.

By using an I/We Indigenous philosophy of being, I argue that emotion, such as the encouragement to cry at burials and rejoice with loud shouts of joy at a fiesta, can be an important saber (knowing) to help understand Indigenous identities as connected, collective, and ancestral ways of knowing and being in comunalidad that re/humanize Indigenous collective relational understandings. An Indigenous philosophy based on a personalized exercise of, and reflection on experience, individual and collective memory, and struggle that explores being Indigenous based on our his- her- and they-stories of survivance is vitally important. Such is the experience of the Nocutzepo mothers' collective movement for a better education that began as a struggle for equity and fair treatment and has endured to become a journey to reclaim an indigena identity based on comunalidad and co-labor that sustains the pueblo even despite the divisions and ruptures of pueblo life. Through the use of oral traditions, the body as a historical collective archive, and yes even community-committed politically active social research (Amigo 2019), pueblo saberes (knowing) can help unpack colonial frameworks and discourses that are fundamental to re/centering Indigenous collective community knowledge(s) (Borunda and Murray 2019). Greater relational and ethical consciousness and responsibility are necessary for approaching research and scholarship on identity and historical and intergenerational trauma when working with Indigenous communities. We cannot afford to generalize and compartmentalize experience, despite good intentions, in ways that can homogenize and collectivize deficit perspectives, victimization, and pathology upon Native and Indigenous communities. Finally, to return to my book project, I contemplate refusal (Tuck and Yang 2014) and I am not sure how to resolve it. Will this book I am working on come to end? That is yet to be seen.

Funding: This research was funded by Fulbright-García Robles grant.

Conflicts of Interest: The author declares no conflict of interest.

\section{References}

Alberto, Lourdes. 2016. Nations, Nationalisms, and Indígenas: The "Indian" in the Chicano Revolutionary Imaginary. Critical Ethnic Studies 2: 107-27. [CrossRef]

Amigo, Santiago B. 2019. Investigación Social y Acción Política. Encartes Antropológicos 2: 163-96.

Anzaldúa, Gloria. 1987. Borderlands/La Frontera. San Francisco: Aunt Lute Books.

Aquino-Moreshi, Alejandra. 2013. La subjetividad a debate. Sociologica 28: 259-78.

Barillas Chon, David. 2018. Ref/lecciones: Lessons for my Hijo and Other Children of Indigenous Immigrants. InterActions: UCLA Journal of education and Information Studies 15. Available online: https://escholarship.org/ uc/item/6c83x9dv (accessed on 25 May 2019).

Batz, Giovanni. 2018. La Lucha contra Megaproyectos en la Región Ixil y las Violaciones de los Derechos Indígenas. In Pensar Guatemala Desde la Resistencia: El Neoliberalismo Enfrentado. Edited by F\&G Editores. Guatemala: Prensa Comunitaria. 
Beltrán, Ramona, and Stephanie Begun. 2014. 'It is Medicine': Narratives of Healing from Aotearoa Digital Storytelling as Indigenous Media Project (ADSIMP). Psychology and Developing Societies 26: 155-79. [CrossRef]

Borunda, Rose, and Amy Murray. 2019. The Wisdom of and Science behind Indigenous Cultural Practices. Genealogy 3: 6. [CrossRef]

Boyer, Christopher R. 2003. Becoming Campesinos: Politics, Identity, and Agrarian Struggle in Postrevolutionary Michoacan, 1920-35. Palo Alto: Stanford University Press.

Byrd, Jodi A. 2011. The Transit of Empire: Indigenous Critiques of Colonialism. Minneapolis: University of Minnesota Press.

Castellanos, Bianet M. 2009. Building Communities of Sentiment: Remittances and Eomtions among Maya Migrants. Chicana/Latina Studies 8: 1-27.

Castellanos, Bianet M., Lourdes G. Nájera, and Arturo J. Aldama. 2012. Comparative Indigeneities: Towards a Hemispheric Approach. Tucson: University of Arizona Press.

Dawson, Alexander. 2004. Indian and Nation in Revolutionary Mexico. Tucson: University of Arizona.

Cadena, de la Marisol, and Starn Orin. 2007. Indigenous Experience Today. Oxford: Berg.

Duran, Eduardo, and Bonnie Duran. 1995. Native American Postcolonial Psychology. Albany: State University of New York.

Garcia, Santiago Andrés, Maritza Arciga, Eva Sanchez, and Robert Arredondo. 2018. A Medical Archeology of the Human Body as a Trauma-Informed Teaching Strategy for Indigenous Mexican-American Students. Association of Mexican American Educators Journal 12: 128-56. [CrossRef]

Hale, Charles. 2004. Rethinking Indigenous Politics in the Era of the 'Indio Permitido'. Nacla Report on the Americas, report on Race Part 1, 16-21. [CrossRef]

Hernández Castillo, Aída R. 2001. Histories and Stories from Chiapas: Border Identities in Southern Mexico. Austin: University of Texas Press.

Hernández Castillo, Aída R. 2010. Multiple InJustices: Indigenous Women, Law, and Political Struggle in Latin America. Tucson: University of Arizona Press.

Holland, Dorothy, and Jean Lave. 2001. History in Person: An Introduction. In History in Person: Enduring Struggles, Contentious Practice, Intimate Identities. Edited by Dorothy Holland and Jean Lave. Santa Fe: School of American Research Press, pp. 3-33.

Kirmayer, Laurence J., Joseph P. Gone, and Joshua Moses. 2014. Rethinking Historical Trauma. Transcultural Psychology 51: 299-319. [CrossRef]

Maldonado Aranda, Salvador. 2013. Stories of Drug Trafficking in Rural Mexico: Territories, Drugs and Cartels in Michoacán. Revista Europea de Estudios Latinoamericanos y del Caribe/European Journal of Latin American and Caribbean Studies 94: 43-66. [CrossRef]

Martínez Novo, Carmen. 2006. Who Defines Indigenous? Identities, Development, Intellectuals, and the State in Northern Mexico. New Brunswick: Rutgers University Press.

Mignolo, Walter D. 2007. La Idea de America Latina: La Herida Colonial y la Opcion Decolonial. Barcelona: Gedisa.

Ortner, Sherry B. 2006. Anthropology and Social Theory: Culture, Power, and the Acting Subject. Durham: Duke University Press.

Rendón Monzón, Juan José. 2003. La Comunalidad: Modo de vida en los Pueblos Indios. Mexico City: Consejo Nacional para la Cultura y las Artes [CONACULTA].

Saldívar, Emiko. 2018. Uses and Abuses of Culture: Mestizaje in the Era of Multiculturalism. Cultural Studies 32: 438-59. [CrossRef]

Sarup, Madan. 1996. Identity, Culture, and the Postmodern World. Athens: University of Georgia Press.

Smith, Linda T. 1999. Decolonizing Methodologies: Research and Indigenous Peoples. Dunedin: Zed Books.

Speed, Shannon. 2005. Dangerous Discourses: Human Rights and Multiculturalism in Neoliberal Mexico. PoLAR: Political and Legal Anthropology Review 28: 29-51. [CrossRef]

Stephen, Lynn. 1997. Women and Social Movements in Latin America: Power from Below. Austin: University of Texas Press.

Trinidad Galván, Ruth. 2005. Transnational Communities in La Lucha: Campesinas and Grassroots Organizations 'Globalizing from Below'. Journal of Latinos and Education 4: 3-20. [CrossRef]

Tuck, Eve, and K. Wayne Yang. 2014. Unbecoming Claims: Pedagogies of Refusal in Qualitative Research. Qualitative Inquiry 20: 811-18. [CrossRef] 
Urrieta, Luis, Jr. 2003. Las identidades también lloran/Identities also cry: Exploring the human side of latina/o indigenous identities. Educational Studies 34: 147-68. [CrossRef]

Urrieta, Luis, Jr. 2012. Las identidades también lloran/Identities also cry: Exploring the human side of Latina/o indigenous identities. In Comparative Indigeneities of the Americas: Toward a Hemispheric Approach. Edited by M. Bianet Castellanos, Lourdes Gutiérrez Nájera and Arturo J. Aldama. Tucson: University of Arizona Press, pp. 321-35.

Urrieta, Luis, Jr. 2013. Familia and comunidad-based saberes: Learning in an indigenous heritage community. Anthropology \& Education Quarterly 44: 320-35.

Urrieta, Luis, Jr. 2016. Native and indigenous education in the Americas: Indigenous knowledge, systems, equity, and economies. In Education, Equity, and Economy: Crafting a New Intersection. Edited by George W. Noblit and William T. Pink. Basel: Springer International, pp. 161-74.

Urrieta, Luis, Jr. 2017. Identity, violence, and authenticity: Challenging static conceptions of indigeneity. Latino Studies 15: 254-61. [CrossRef]

Urrieta, Luis, Jr., and Sergio Martínez. 2011. Diasporic community knowledge and school absenteeism: Mexican immigrant pueblo parents' and grandparents' postcolonial ways of educating. Interventions: International Journal of Postcolonial Studies 13: 256-77. [CrossRef]

Urrieta, Luis, Jr., and George W. Noblit. 2018. Cultural Constructions of Identity: Meta-Ethnography and Theory. New York: Oxford University Press.

Vásquez Castillo, María T. 2004. Land Privatization in Mexico: Urbanization, Formation of Regions, and Globalization in Ejidos. New York: Routledge.

Vega, Christine. 2018. Othermotherwork: Testimonio and the Refusal of Historical Trauma. International Journal of Qualitative Studies in Education 31: 223-30. [CrossRef]

Vizenor, G. 1999. Manifest Manners: Narratives on Postindian Survivance. Lincoln: University of Nebraska Press.

Yellow Horse Brave Heart, Maria, Josephine Chase, Jennifer Elkins, and Deborah B Altschul. 2011. Historical Trauma Among Indigenous Peoples of the Americas: Concepts, Research, and Clinical Considerations. Journal of Psychoactive Drugs 43: 282-90. [CrossRef] [PubMed]

(C) 2019 by the author. Licensee MDPI, Basel, Switzerland. This article is an open access article distributed under the terms and conditions of the Creative Commons Attribution (CC BY) license (http://creativecommons.org/licenses/by/4.0/). 


\title{
Article \\ Collective Trauma and Mystic Dreams in Zabuzhko's "The Museum of Abandoned Secrets"
}

\author{
Mariia Lenherr \\ Department of Psychotherapy, Sigmund Freud University, 1020 Vienna, Austria; mariia.lenherr@gmail.com \\ Received: 20 October 2018; Accepted: 8 January 2019; Published: 11 January 2019
}

\begin{abstract}
The 20th century of human history was overshadowed by the horrifying events of world wars and totalitarian regimes, with their traumatic experiences becoming the very focus of today's modern globalized society. Psychoanalytic psychotherapy is one of the ways of dealing with this overwhelmingly violent phenomenon. This article will discuss an historical traumatic event through literature, using psychoanalytic theories of trauma. The problem is discussed on the level of the actual theoretical landscape including the relation between transgenerational transmitted trauma, collective trauma, and cumulative trauma inscribed in a "foundation matrix" (Foulkes). As a clinical vignette, the novel "Museum of Abandoned Secrets" by modern Ukrainian writer Oksana Zabuzhko is used. The author addresses the functions of dreams, scrutinizing the psychodynamics of the novel using concepts of projective identification, mourning, the need for repair, and epigenetic and fractal theory. It is suggested that the novel facilitates the characters' journey through trauma and its integration by the large groups (of readers).
\end{abstract}

Keywords: collective trauma; dreams; psychoanalysis; literature; Zabuzhko; transgenerationally transmitted trauma

\section{Note on the Methodology}

This article uses the psychoanalytic literary exegesis method and is situated in the field of hermeneutics. Psychoanalytic literary exegesis adopts psychoanalytic theories of interpretation, by stipulating that literary texts are similar to dreams constructed using the mechanisms of condensation, repression, displacement and symbolism. Early psychoanalytic reading methods were focused mainly on text itself; later theoreticians (e.g., Ogden) shifted the focus on the relationship between the reader and the text, author and the text, employing psychoanalytic concepts such as projective identification, containment etc. For a further discussion on this, please refer to my article, "Gender Aspects of the Transgenerationally Transmitted Trauma in "The Museum of Abandoned Secrets" by Oksana Zabuzhko" (Zabuzhko [2009] 2012), in Dynamic Psychiatry Magazine (Lenherr 2018).

\section{Introduction}

Psychoanalysis and literature have had a rather long and rich interdependent history. Freud wrote a number of important essays that interpret literary pieces, and many of his successors were passionate readers. In fact, some of the milestone theoretical concepts in psychoanalysis were borrowed from the world of literature (e.g., Oedipus complex, the notion of narcissism).

Psychoanalysis theory originated with the concept of trauma: after his mentor, Charcot, Freud hypothesized that while hysterical patients suffer from traumatic reminiscence, there were also personal traumatic experiences involved. In Freud's case, these experiences include (1) a bitter episode of humiliation faced by his father due to his Jewish origin, that Freud often ruminated on; (2) the premature death of his sibling, Julius, followed by his ostracism by the conservative Viennese Medical society, and finally; (3) the sad fate of Freud's sisters after he fled from Nazi 
aggression to London. Freud's life and work is a stunning memoir of how he worked through his trauma. He can be seen as a representative for the established groups of his time (e.g., Jews, doctors, surviving siblings etc.). A discussion about one's individual identity inevitably includes groups that an individual belongs to. It is true that trauma shared by a group has an influence on every individual in the group, affecting both the individual and group identity of a person. There are various levels of trauma discussions within the modern psychoanalytic theory. In this paper, however, I will reflect on those with relevance to this clinical vignette: (1) the concept of a cumulative trauma; (2) transgenerationally transmitted trauma; and (3) collective trauma. All of these traumatic phenomena have a common denominator which can be explained by the concept known as the "foundation matrix" introduced by Foulkes in 1964. The foundation matrix is defined as "the network of all individual mental processes, the psychological medium in which they meet, communicate, and interact" (Foulkes and Anthony 1965, p. 26). The "foundation matrix" is, essentially, the conceptual metaphor for group psychoanalysis. It combines concepts such as "group" and "mother", as Foulkes postulated: often, probably, as a rule, the group represents the mother image (think of motherland, AN (author's note)), and that is why the term "matrix", derivative of māter (mother) is used (Foulkes 1974). The foundation matrix has an ontological quality which is an essential for all communications in a group, verbal or non-verbal (Weimer 2017, p. 1122), and is especially relevant for culture and society. Methodologically, we are situated in the tradition of the dream interpretation, in the realm of Verdichtung, condensation. (Freud 1900, p. 313). This concept has conclusive similarities to the Jungian idea of "collective unconscious" (Jung [1916] 1953) and the Bionian concept of "group animal" (Bion [1961] 1989). It is important to understand how different traumatic experiences affect an individual in a group and a foundation matrix of a group in order to learn more about a trauma repercussion and to diminish the risk of the repeating of the collective trauma in the future.

In 1963, Khan defined cumulative trauma as the result of breaches in a mother's role as a protective shield over the course of the child's development, from infancy to adolescence, tendering the fact that the mother is unable to provide sufficient auxiliary ego to support her child (Khan 1963, p. 290). But what if a mother herself inherited from her parents her protective shield with holes? This brings us to the realm of transgenerationally (also known as intergenerational) transmitted trauma. It should be pointed out that transgenerational transmission is a necessary condition for any individual and group development as it gives a feeling of continuity, attachment, and security, which are fundamental for healthy development. The best grandma's pie is baked when the child observes his grandmother often enough to be able to replicate her actions spontaneously. The problem with transgenerationally transmitted trauma is that traumatic experiences, emotions, and coping mechanisms associated with any traumatic event, or process, might be unconsciously repeated. Our understanding of transgenerationally transmitted trauma at a group level owes a great deal to studies about second and third generation Holocaust survivors, and others directly traumatized under the totalitarian regimes. References to many studies on this topic can be found in Kogan 1995; Kestenberg and Brenner 1996; Volkan et al. 2001, 2002; Faimberg 2005; De Mendelssohn 2008; Drexler 2017.

Our "post-traumatic" century, sadly enough, has inherited massive amounts of trauma, which is shared by large groups of people belonging to a certain culture, either nationally, or geographically. Collective trauma (or chosen trauma) constitutes an important part of the group's identity and is to be understood in this article as a traumatic effect of an event or a process shared by groups of individuals and one that can be transmitted transgenerationally and across communities. Triggers of collective traumas include war, genocide, slavery, terrorism, and natural disasters etc.

Collective trauma has a certain interdependence with transgenerationally transmitted trauma, but not every transgenerationally transmitted trauma is collective trauma, and not all collective trauma is necessarily transmitted transgenerationally. Why is it important for an analyst to differentiate between these types of trauma? An analyst who is not aware of the effects of the social and historical circumstances of the patient's inner objects risks diminishing the reflective space. In analysis, one has 
to be ready to telescope through generations, as Faimberg (2005) aptly puts it in her book, in order to understand the echo it still has in the patient's life.

Transgenerationally transmitted trauma outside of the clinical setting is often dealt with through literature. This can be understood as an associative elaboration on collective trauma by a member of a traumatized group, namely the writer. As avid readers and writers, Freud and his disciples recognized the creative genius of literature in its ability to offer a profound understanding of human nature through the study of characters and their actions. Freud's noteworthy essays on literature and his influential papers on Shakespeare, and the works of Dostojewskij and Hoffmann also remain thought-provoking with their timeless relevance.

The most profoundly analyzed literary piece is undoubtedly "Gradiva" written by Wilhelm Jensen in 1902. In the foreword to Freud's essay "Delusion and Dream in Jensen's Gradiva", Stanley Hall (1917) acknowledges that as "an introduction to psychoanalysis, it is an extended illustration of "mysterious ways of unconsciousness". Freud's essay vividly asserts, and I firmly believe as well, that psychoanalytic theory is a powerful tool in literary criticism and culture, and one that legitimizes literary texts. Freud implies that the author Jensen, a novice in psychoanalysis, inherited "native psychotherapeutic instincts" which allowed him to describe psychic mechanisms that obviously belong to the domain of psychoanalysis, which, in turn, makes the novel both a case study and a dream book at the same time (Freud 1907). In this respect, the novel discussed in this article can be seen as a case study of a dream book.

In fact, in 1930 Freud was awarded Goethe's literary prize for his extensive literary work, and was held in high esteem among creative authors throughout his professional life:

"Storytellers are valuable allies, and their testimonies are to be rated high, for they usually know many things between heaven and earth that our academic wisdom does not even dream of, in psychic knowledge, indeed, they are far ahead of us ordinary people, because they draw from sources that which we have not yet made accessible for science." (Freud 1907, p. 123)

These words, written over a hundred years ago, have granted the literary field meaning and possibility of psychological insight otherwise accessible in the analytic treatment exclusively, making literature an uncanny twin of psychoanalysis. Freud suggested that his case stories should be read like novels and in the "twin" logic, the following novel written by a modern Ukrainian writer, Oksana Zabuzhko, is read as a case study.

\section{Clinical Vignette}

During the 20th century, the Ukrainian people experienced major periods of violence and were massively exposed to collective trauma, i.e., deliberate human actions that directly and principally affected the whole nation as a group. I would like to draw your attention to a few historical events related to this man-made disaster (Man-Made Disaster n.d.).

1932-1933: The Holodomor, deliberately induced genocide within Stalin's policy, was responsible for up to 12 million deaths from starvation in Ukraine.

1923-1961: The Gulag, a system of forced labor camps, comprised de-facto concentration camps for everyone who could endanger Stalin's regime, i.e., every rational thinking person or intellectual elite. Russian writer and Gulag survivor, Alexander Solzhenitsyn, wrote about his Gulag experience in his Nobel winning book "The Gulag Archipelago" (Solzhenitsyn 1973).

Among others, as a response to the oppression(s) in Ukraine, the Ukrainian Insurgent Army (UPA) was created. It existed during 1942-1956 and consisted of military, political, intelligence, and political education departments. Ideologically, the UPA was closely aligned with the underground nationalist political party (OUN). Structurally, the UPA was divided into four main units: UPA-North, UPA-West, UPA-South, and UPA-East. The events described in the novel refer mainly to the UPA-West operating in Halychyna, Bukovyna, and Zakarpattia and embrace the period of the Red Army occupation in 1942-1950. The military activity of UPA and OUN is still considered to be very controversial and 
calls for further historical and political research. However, the root of problem lies in the fact that the Soviet regime eradicated the majority of its documentation and annihilated the archives. This makes any investigation exceedingly difficult, if not impossible, for the later generations. The trauma of "not-knowing" one's own origins, of being cut off from one's own family roots is thus inscribed in the personal histories of many Ukrainian families even today. The novel, "The Museum of Abandoned Secrets", captures this perfectly.

As previously posited, Jensen's Gradiva can be seen as the introduction to psychoanalysis. In this light, it can be suggested that the novel also be regarded as a case study for transgenerationally transmitted trauma, notwithstanding. It perfectly exemplifies how individual and large group identities become inextricably intertwined in a fractal-akin way, quoting the biogenetic law that states that "ontogeny recapitulates phylogeny". Fractal is a recursive self-similarity set in mathematics, and also present in abundance in nature: sea-shells, lightning, romanescu, corn flakes etc., which to my point, illustrates well the correlation between an individual and a group identity within one person (Mandelbrot 1983).

The novel, "The Museum of Abandoned Secrets", was published in 2009 in Ukraine and since then has been translated into many languages. It has won major domestic and international awards, e.g., The Best Ukrainian Book Award in 2010 according to the magazine Korrespondent, and was short-listed for the BBC book of the year (2010) and the "Angelus" Central European Literature Award in 2013. The aforementioned novel attempts to give a voice to the concept of trauma, which has been so deeply entrenched in Ukrainian history. Zabuzhko calls this type of literature one that has the courage not to please or entertain the reader, but to name things, which are excruciatingly painful. Applying this logic, the author sees her book as a cumulative experience of thinking. "It's time in our culture", she says, "to gather it." (Zabuzhko 2016, p. 15).

The title of the novel alludes to some meaningful enigmas, which have been deserted for a reason. They are meaningful because if they had no sense and value to a group of people they would not appear in a museum. The novel has a certain value for a psychoanalytical researcher as well as it shows how trauma transmitted through generations is experienced and how it is placed in the unconsciousness of the person, how huge the urge to find out the truth is, how trapped in the past one can be and how existentially important it can be to work through the trauma. Furthermore, the novel illustrates the functions of dreams with respect to finding the truth. Wilfred Bion argued that dreaming is the most elaborate form of thinking and that the innate truth drive is a crucial vehicle for the curiosity (Bion [1961] 1989). Likewise in the novel, it is through the dreams that the threads of the bigger narrative are formed into a comprehensive picture that has its value and place in the psychological/psychohistorical museum of the epoche and continues to hold personal significance for the protagonists. Events in the novel convincingly maintain that it is the third generation that has to deal with a collective trauma and there is an evident historical logic to this. If somebody is a carrier of cumulative trauma, his/her ability to deal with stress that inevitably emerges when researching on family/national trauma is diminished also on a neurological genetic level.

The plot in the novel evolves as follows: in 2003, Daryna Goschinska, a television journalist, discovers a worn photograph of Olena Dovgan, a member of the Ukrainian Insurgent Army (UPA), who was killed in 1947 by Stalin's secret police. Daryna, intrigued by the photo, decides to make a documentary about Olena's life and death. During her research, she meets the great nephew of Olena, who later becomes Daryna's partner. They continue to investigate this case together, but the much-needed archives were destroyed at the time, making it impossible to discover the truth behind the events that took place. Although, the duo meet relatives of the people who had some relation to Olena's story, they were also oblivious to its true facts, and it is the reader alone who has a holistic picture of the events: in 2003 they were in search of the something that no longer existed, yet, while asleep, they dreamt of the true story of the investigated object, Olena, but they were unaware of the intricate facts of the dream. Seems mystical, does it not? 
There are several passages in the novel alluding to the fact that what they dealt with might extend throughout their lives. Evidently, it had a lot to do with their parents and grandparents and Ukrainian history, i.e., transgenerational transmission. For example, "that dream of mine, the one dreamt two weeks ago, on that wild night, the night that would not end, as if Aidy [Adrian, AN] and I have lived several lifetimes in that single night, on the verge between dream and wakefulness" (Zabuzhko [2009] 2012, p. 527).

Daryna reflects on the generation of her parents and the purports they left to the children, she tries to make sense of their their unconscious messages:

“[ . . ] This strength of theirs [parents, AN] the one that seemed so wasted because it hadn't been translated into anything tangible-turned out great enough to confer upon their child her own margin of safety. So that in a different era, in a different country, packed with deaths like a can with sardines this child would remain alive." (Zabuzhko [2009] 2012, p. 279)

The question of heredity interested her the most, because Zabuzhko herself stated that the function of this novel is to restore the broken connection between time and generations:

"You loaded us with emptiness, and now we're passing it on the next generation."

(Zabuzhko [2009] 2012, p. 278)

This emptiness desires to be understood and nevertheless to be made use of. This emptiness is similar to an "airbag", it is necessary to hold the inherited traumatic elements apart from the psyche, so one feels, as if we do not know that it is empty, and it goes well with the need to forget, not to remember-as powerful as its antipode- the need to know the truth about one's own past.

How does one survive such inherited trauma, how does one cope with the unspeakable and unimaginable? One does not have much choice: either to perish or to become a hero, and this is how we find it to be in the novel: "[ ... ] sometimes, the thing that does kill us makes our children stronger." (Zabuzhko [2009] 2012, p. 279).

The appalling encounter continues to echo in the lives of the generations to come:

“[ ... ] Several generations' worth of survival experience-of those packed off into camps, stripped off their property as kulaks, deportation of the heroes of Grandpa's tales about Karlag, all their long-forgotten skills." (Zabuzhko [2009] 2012, p. 303)

It is crucial for one's own identity to know one's past, to have a gravestone, where one can come to, to feel the family "grounding"; it gives a feeling of a historical right and a logic of one's own existence in this very place and time. When the family history and mythology is not available, it sets in motion an ever-present anxiety and an almost existential curiosity, which when not satisfied turns to depression.

One has to make sense of the signs left from past, even when there are no words: "We don't know how to hear their silence; we live as if they never existed. But they did. And their silence is the stuff of which our lives are made" (Zabuzhko [2009] 2012, p. 604). Also, the silence and the unknown has to be deciphered in order to understand who one is. And the different ways of ascribing meaning to the past are, in turn, created.

As the two young people go deeper into research, their dreams became bizarre, almost uncanny. Adrian's dreams are especially odd to him. These dreams, though traumatic, offer a lot of material, which Daryna and Adrian are able to weave in with some scarce facts that they have about Olena. The plot lines in the novel evolve as if in parallel: one line takes place "now" in the newly independent Ukraine in Kyiv, and another one in Lwiw and its outskirts of late 1950s. These plot lines only cross in the dreams of the protagonists, mostly Adrian. The reader is in a privileged position to know and to understand what has happened in the past and what kind of influence it has on the lives of these two young people, similar to that in a psychoanalytic situation, suggesting that only from the distance or with a help of the third agency (as in a dream) can the whole picture be captured. Dreams offer a backdrop, a stage for working through the traumatic material that for whatever reasons (fear, 
for example) are not accessible in the conscious state. Unlike reality, a dream has a beginning and an end.

Adrian dreamt about the life and the death of Olena and the men around her, especially one UPA soldier (also called Adrian), who loved her and died with her, as if in a documentary:

Daryna: "Do you mean to say [ . . . ] that you are seeing someone else's dreams?"

Adrian: "It's more precise to say that I'm dreaming someone else's consciousness. [ . . . ]I know it's not my memory." (Zabuzhko [2009] 2012, p. 117)

Dissociated memories are experienced by Adrian as intrusive, lost, disconnected, like chronicles he doesn't choose to deal with.

“Unlike regular dreams, they're utterly emotionless. No joy, no fear, no anxiety, no arousal, nothing-only stories; [ . . . ] If these are, in fact, memories, they must come from a disconnected brain." (Zabuzhko [2009] 2012, p. 126)

It is a remarkable fact that Olena's grandnephew ("the modern" Adrian, partner of Daryna) and the man who loved Olena, and who was loved by her sister, grandmother of Daryna's partner, (but I am not going to dwell on the sibling rivalry topic in this paper), have the same name-Adrian. The "modern" Adrian is himself a carrier of many traumatic secrets of his family, to which his name works as a signifier, the mark that indicates more secrets in this respect. Only through the dreams does he get in touch with this part of his own family narrative. Adrian in 2003 dreams about the life of the Adrian in the 1940s making this is another allusion to a relationship between dreaming, memory, and transgenerational trauma in the novel: "This is not a dream [ . . ] Something tormenting this man, something too big for one person." (Zabuzhko [2009] 2012, p. 393).

After completing their research, which was rather turbulent, Daryna gets pregnant, but this baby has more of a metaphorical meaning, as if a benign resolution of the riddles of the past and a signifier of maturation and of successfully working through the transgenerational trauma.

Similarly in Gradiva, the author also offers a remedy for the main heroes: once they found an explanation for their mentioned silence and emptiness, one which is emotionally acceptable and plausible, they could continue on being, concentrating on their own lives and love relationships.

\section{Theoretical Considerations and Reflections on the Psychodynamics of the Novel}

How is something like this possible?

What importance do we deduce from psychoanalytic theory in order to understand the psychodynamics of the novel?

In which way is the dreaming phenomenon related to the collective trauma and its transgenerational transmission?

The reiteration of the name Adrian is not just a clever twist in the plot; it also has a deeper psychodynamic meaning. At this juncture, it is worth mentioning the Israeli psychotherapist, Dina Wardi, who describes in her book "Memorial Candles" (Wardi 1992) the name phenomenon, when survival's children are given the same names as their perished relatives. The idea behind it is to substitute the lost object and to avoid mourning, implying that the second and the third generations have a double identity (and often the double burden of expectation to be fulfilled not just for oneself, but also for a killed, disappeared and the dead family).

Taking a look at Adrian's dreams, which are, put simply, "emotionless", "disconnected", like "from somebody's else", they feel like "something too big for one person's life" and "emptiness". The syntax of a traumatic discourse is easily recognizable here with its typical features: overwhelming quality, dissociation, splitting, and estrangement. In the novel, it is presented in the form of a dream narration. Freud considered his work "Interpretation of Dreams" his best writing as it describes the universal mechanisms of the unconsciousness, which are also valid for creativity. In turn, the dream 
utilizes "a poetic diction" of a lyrical poetry as Ella Sharpe puts it (Meltzer 2009, p. 27). In short, in the context of the novel, what we face is a traumatic experience inscribed into the dream life of a subject, reinforcing psychoanalytic theories on dreams and collective trauma.

According to Freud, the dream is made of the three main elements: day residue, wish fulfillment, and infantile experience. Freud believed we have to decipher the dream's meaning in order to apprehend the truth. In later decades, philosophers (Wittgenstein, Langer) moved to a Neo-Platonic view, suggesting that the meaning has to be generated and deployed (Meltzer 2009, p. 26). If we consider Bion, who perceived dreaming as a most profound way of thinking, we map dreams as a room to think about the unthinkable, to convert bizarre beta elements into alpha elements, to sew the traumatized tissues together into a new coherent narrative. If we consider theories of Donald Meltzer (2009), we can see how dreams in the novel fulfill the epistemological function by creating the subjective knowledge, impossible to access otherwise.

Applying Freudian theory to the dreams in the novel, we can propose that: (1) day residue is the investigation's project-Olena Dovgan and her heroic life; (2) the wish fulfillment is the striving of Adrian and Daryna to find the truth about Olena's life and death; and (3) the infantile experience, the most interesting part for us, is connected to transgenerationally transmitted trauma. Here Adrian "uses" his unconscious and fragmented conscious memories of his grandmother Apolinaria and grandaunt, Olena, that are set in motion by his positive transference to Daryna and some other unconscious material transmitted by his parents and grandparents, as Gampel (1986) and Kogan (1995) suggested "through a massive process of projective identification to contain the mourning and aggression that they [older generations, AN] would otherwise have had to feed themselves and which might have made them self-destructive" (in De Mendelssohn 2008, p. 390). Volkan proposed that 'the offspring of the victimized generation becomes the reservoir for unresolved mourning and "deposited representations." The "deposited image" (Volkan 1987) becomes a psychological "gene" that, in turn, influences the child's identity and self-representation, initiating certain tasks that the child is obliged to perform without the parent or other caregivers ever verbalizing the demand (Volkan et al. 2002, p. 36).

At this point a short detour to the field of epigenetic is needed in order to understand the correlation between biological and psychological genes, as the cortisol research on mothers diagnosed with a posttraumatic stress disorder proved that their babies also have a reduced cortisol level (Yehuda et al. 2005) Previously the group of researchers could prove that Holocaust survivors also had a reduced level of cortisol mirror (Yehuda et al. 1998, 2002). Similar conclusions have been derived by "the suicide brain research": the anti-stress gene is "turned off'" when people have been traumatized in their early childhood and for pregnant women who experience domestic violence (Meany et al. 2008; McGowan et al. 2009; Radtke et al. 2011). ${ }^{1}$ In this respect it is worth briefly introducing the results of the Dutch Famine Birth Cohort Study, which focused on the epigenetic consequences of the hunger experience. It is a proven fact that the following generations were significantly smaller, although they were conceived in times when nutrition was in abundance. Obviously the genetic material of grandchildren contains the epigenetic level of the information about their grandparents' life conditions (Drexler 2017, p. 26). Why is epigenetic discussion addressed in this psychoanalytic paper? Because Eric Kandel, the Nobel Prize winner, suggested that successful psychotherapy, with alterations of the genetic expressions including epigenetic changes, leads to "structural changes in the brain" (Kandel 2006). This scientific breakthrough gives us hope for a better future as a humane society without blindly acting out on collective and transgenerational traumas.

Retracting back to Adrian, it is still an open question if he fell in love with Daryna because of his feelings for her and a result of him supporting her in her research, or because he had an unconscious need to find somebody who could construct and narrate the life story of his heroic great aunt.

1 Personal intereview. 
Being a psychoanalyst I am prone to yield to the second hypothesis. Why would he need to find someone to reconstruct the life story of his great aunt? There are, primarily two reasons which are truly therapeutic. Firstly, heroic epos, which would appear as a result of this research, could ground and epitomize his great-aunt's life. It could be used as an antidote to the shame, often experienced by the traumatized group and to appease the anxiety of not knowing or filling typical emptiness. Secondly, the need for reparation of the traumatized memory is used in her film, on the collective level, to rehabilitate many (Ukrainian) people-which is Daryna's deliberate aim. Similarly, Adrian is motivated, on a personal level, to restore the generational connections within his family.

It can be assumed that through the projective identification and unconscious reasons coming from the sources described above motivated Daryna and Adrian to undergo the investigation in the first place. It is the need for reparation and the urge to work through the trauma of the past that propelled the writer Oksana Zabuzhko to write this novel in this particular way. This article as well is inspired by the same source i.e., the echo of a transgenerationally transmitted trauma still operating in the unconsciousness of the author of this article.

"Museum of Abandoned Secrets" can be seen as a heroic epos. De Mendelssohn suggested that it is necessary for a traumatized group to have such epos: "In many different ethnic groups having suffered extreme persecutions, or even among individuals whose traumatic experiences have been in the public eye, the victims may feel that they are somehow forced, or must at great cost, force themselves, into becoming 'dignified' role models for others by always being the first to forgive their injuries and deny their insecurities, however, they can only have the courage to be what they are, whatever that may be. The 'heroic solution' is in adopting an ideological group identity to mask the shameful past." (De Mendelssohn 2008, pp. 393-94). He continues to further explain this way of working through the trauma: "Once this ideological pride, is resolved, a movement toward remembering, and thus mourning can begin." (De Mendelssohn 2008, pp. 397-98)

Mourning is a sign of a psychic maturation and a process, which accompanies an integration of trauma. As many other psychics assert, mourning should happen and indeed does happen on both levels: individual and group. I believe that there exists a special relationship between the individual and collective levels of functioning. It is best described using the theory of fractals which asserts that what looks like chaos from the individual perspective evolves into a structure with rigorous inner logic once seen from a historically wider and chronologically longer perspective. This can be compared to a visualization of a Mandelbrot set (Mandelbrot 1983), which exhibits an elaborate and infinitely complicated boundary that reveals progressively ever finer recursive detail at increasing magnifications. It seems that, in this case, literature combines mathematics and the products of the human psyche.

Ukrainian literature, in the last decade, produced a considerable number of novels which deal with the trauma experienced over a few generations or a few lifespans. Some authors worth mentioning include Jadan, Lys, and Słoniowska. Their books fulfill the same function which was aptly formulated by Zabuzhko: to bridge the historical tissues and to restore the connections between generations. It would appear that this function has a universal meaning, which reflects the Zeitgeist. This alludes to the fact that there is a need to narrate such stories, which are often made up of family memories built over a few generations. When reading such books, the collective mourning process can emerge, less driven by guilt than by a genuine sense of loss and an appreciation of what was damaged or destroyed in the past. When we are dealing with the more complex phenomenon of transgenerational shame, the most that we can usually do is to trace the personal histories involved, which are offered to the reader by the novels. Shared mourning strengthens the cohesiveness and the reflective capacities of the whole group, and thus historical literature facilitates a work through of some hitherto unseen aspects of what Foulkes termed the "foundation matrix" of the group (Foulkes 1978). Thus, there is an inherent need to read such stories, which make such historical novels (and "the witness literature" as Elie Wiesel put it) very much sought-after. 
But it is not just a Ukrainian phenomenon; Volkan describes his work in a psychiatric hospital with African-American youngsters, who collectively wrote poems to express their inner feelings and thoughts (Volkan 1963, 1966).

In the same vein, Lily Brett (1999), in her novel "Too Many Men" presented a female protagonist who is tortured by nightmares, she is unable to comprehend. Only after her trip to Poland, accompanied her father, does she realize that her dreams mirrored her parents' experience where both survived Auschwitz (in Drexler 2017, p. 20). Similarly, Zabuzhko's novel is also based on the reminiscences and memoirs of the UPA soldiers, which she had collected before writing the book. This process of transforming the subjective oral narrative into a written literary piece that survived the horrific and verbalizing effect of what was once the unspeakable, has, in itself, a therapeutic effect on being a witness and bearing the truth. The author, in this case, serves a mediating and containing function offering a space for a reader where identification, mourning, remembering, and thus, integration is possible. The reading of this type of literature provides the opportunity for a catharsis effect on the reader through the creation of the mental space, where collective trauma has a chance to be psychically worked through.

\section{Conclusive Remarks}

In short, transgenerational trauma and its silent effects cannot be ignored. This phenomenon is reflected in real-life circumstances of affected societies, including continuing poverty, impingements of democratic way of life, and corruption in a political system, including international manipulation, crimes, acting out on rage and aggression, intolerant splitting of countries, and the rise of right-wing ideologies. Psychoanalysis started as a cure discipline, but is surely applicable as a cultural criticism theory to explain the political and societal challenges as well as the developmental dead-ends with a high probability of truth, which as a tradition of group analysis (which also appeared in the time of world crisis) demonstrates its relevance when trying to understand the wide range of social and cultural phenomena concerning trauma. Literature, as a realm where individual and group psychic phenomena are creatively represented, is a reflection of human history including all its collective and individual wounds. It is a highly complex way to deal with a transgenerational transmission. In its positive component, transgenerationality provides the feeling of continuity and tradition, a necessity for survival.

On the individual level, we need to be made aware of a possible transgenerationally transmitted trauma in order not to overlook the repercussions of the experience of the previous generations in the conscious and unconscious worldview of our patients.

I hope to demonstrate how a literature piece can facilitate a working-through of the trauma, as it is inherited and shared by the large groups. The rising interest in this topic indicates the need for this problem to be addressed in a modern culture. It is easy to see that if looked at more often and more openly i.e., via literature and art, the insights into the unconscious dynamics of a transgenerational trauma transmission has the potential to interrupt the repetitive cycles of violence.

The novel "The Museum of Abandoned Secrets" offers a vivid and evocative vignette on how collective trauma embedded in literature and dreams can help to uncover trapped and wounded memories. Psychoanalytically, the novel might be seen as a return of repressed memories through the dreams from the unconscious ocean of the national collective trauma. There is still much research work to be done concerning the topic as postulated by Freud: "It remains an open question, how much the individual thinker or writer owes to the stimulation of the group in which she/he lives, and whether she/he does more than perfect a mental work in which the others have had a simultaneous share" (Freud 1921, p. 83).

The union of psychoanalysis and literature has proven, time and again, to be a solid one, where the mutual enrichment of new analytical concepts and neoteric insights in the work of literary expression are born. Literature and psychoanalysis work on the same subjects, helping all of us of to digest and integrate the traumas from the past. The new challenges faced by our society provides the need 
for a more relevant vision and comprehension, reinforcing the need for further work to be done in this respect.

The main outcomes of this article are:

The reflection (once again) upon the intercorrelation between the psychic mechanisms discovered in psychoanalysis and enigmas of the soul as represented in a literary world.

I hoped to show or validate the importance of literature in a process of working through collective trauma and to allude to the role of the author, reader, and group in this process.

Furthermore, it was demonstrated how dreams in a literature piece could facilitate the process of dismantling the trauma narrative as well as facilitating further integration and psychic development, not just for the main protagonists, but, possibly for the writer and readers.

It was illustrated how the scientific insights from conterminal sciences such as biology, philosophy, and fractal geometry could help to validate psychoanalytic concepts of trauma, for individuals and the group.

Funding: This research received no external funding.

Conflicts of Interest: The author declares no conflict of interest.

\section{References}

Bion, Wilfred R. 1989. Experiences in Groups and Other Papers. London: Tavistock Publications. First published 1961. De Mendelssohn, Felix. 2008. Transgenerational Transmission of Trauma: Guilt, Shame, and the "Heroic Dilemma". International Journal of Group Psychotherapy 58: 389-401. [CrossRef] [PubMed]

Drexler, Katharina. 2017. Ererbte Wunden Heilen. Stuttgart: Klett-Cotta Verlag.

Faimberg, Haydée. 2005. The Telescoping of Generations: Listening to the Narcissistic Links Between Generations. London: Routledge.

Foulkes, Siegmund Heinrich. 1974. Gruppenanalytische Psychotherapie. Stuttgart: Klett-Cotta Verlag.

Foulkes, Siegmund Heinrich. 1978. Praxis der gruppenanalytischen Psychotherapie. München: Ernst Reinhardt.

Foulkes, Siegmund Heinrich, and Elwyn James Anthony. 1965. Group Psychotherapy, 2nd ed. London: Karnac Books. Freud, Sigmund. 1900. Die Traumdeutung. Wien: Franz Deuticke.

Freud, Sigmund. 1907. Delusions and Dreams in Jensen's "Gradiva". The Standard Edition of the Complete Psychological Works of Sigmund Freud, Volume IX (1906-1908): Jensen's "Gradiva" and Other Works. Trans. from the German under the General Editorship of James Strachey. 24 vols. London: Hogarth Press and the Institute of Psycho-Analysis, pp. 1-96.

Freud, Sigmund. 1921. Group Psychology and Analysis of the Ego. The Standard Edition of the Complete Psychological Works of Sigmund Freud, Volume XVIII (1920-1922): Beyond the Pleasure Principle, Group Psychology and Other Works. Trans. from the German under the general editorship of James Strachey. 24 vols. London: Hogarth Press and the Institute of Psycho-Analysis, pp. 1953-74.

Jung, Carl Gustav. 1953. The Structure of the Unconscious (1916), Collected Works. Princeton: Princeton University Press, vol. 7, pp. 263-92. First published in 1916.

Kandel, Eric. 2006. In Search of Memory: The Emergence of a New Science of Mind. New York: W.W. Norton \& Company. Kestenberg, Judith S., and Ira Brenner. 1996. The Last Witness: The Child Survivor of the Holocaust. Washington, DC: American Psychiatric Press.

Khan, M. Masud R. 1963. The Concept of Cumulative Trauma. In The Psychoanalytic Study of the Child. London: Taylor \& Francis Group, vol. 18, pp. 286-306. [CrossRef]

Kogan, Ilany. 1995. Kurative Faktoren in Psychoanalysen mit Kindern von Überlebenden des Holocaust vor und während des Golfkrieges. Jahrbuch der Psychoanalyse 34: 181-205.

Lenherr, Mariia. 2018. Gender Aspects of the Transgenerationally Transmitted Trauma in "The Museum of Abandoned Secrets" by Oksana Zabuzhko. Dynamische Psychiatrie 51: 208-19.

Mandelbrot, Benoit B. 1983. The Fractal Geometry of Nature. American Journal of Physics 51: 286. [CrossRef] 
Man-Made Disaster. n.d. In the Law Dictionary online. Available online: https://thelawdictionary.org/manmade-disaster/ (accessed on 24 December 2018).

Meltzer, Donald. 2009. Dream-Life: A Re-Examination of the Psychoanalytic Theory and Technique. London: Karnac Books. Solzhenitsyn, Aleksandr. 1973. The Gulag Archipelago. Paris: Éditions du Seuil.

Volkan, Vamik D. 1963. Five poems by Negro youngsters who faced a sudden desegregation. Psychiatric Quarterly 37: 607-17. [CrossRef] [PubMed]

Volkan, Vamik D. 1966. Some of the psychodynamic processes of two Negroes with leukodermia. Psychitric Quarterly 40: 34-42. [CrossRef]

Volkan, Vamik D. 1987. Psychological concepts useful in the building of political foundations between nations: Track II diplomacy. Journal of the American Psychoanalytic Association 35: 903-35. [CrossRef] [PubMed]

Volkan, Vamik D., Gabriele Ast, and William F. Greer. 2001. Third Reich in the Unconscious: A Study of Transgenerational Transmissions of Shared Trauma and its Consequences for Identity Formation. Philadelphia: Brunner-Routledge.

Volkan, Vamik D., Gabriele Ast, and William F. Greer. 2002. Third Reich in the Unconscious. London: Taylor \& Francis. Wardi, Dina. 1992. Memorial Candles. London: Routledge.

Weimer, Martin. 2017. Zur Diskussion der Gruppenanalytischen Matrixmetapher. Psyche 12. Stuttgart: Klett-Cotta Verlag, pp. 1121-51.

Zabuzhko, Oksana. 2012. The Museum of Abandoned Secrets. Translated by Nina Shevchuk-Murray. Las Vegas: Amazon Crossing. First published in 2009.

Zabuzhko, Oksana. 2016. And again I'm getting into a tank (I znovu ja vlizaju v tank). In Chosen Texts 2012-2016: Articles, Essays, Interviews, Memoirs. Kyiv: Komora.

(C) 2019 by the author. Licensee MDPI, Basel, Switzerland. This article is an open access article distributed under the terms and conditions of the Creative Commons Attribution (CC BY) license (http:/ / creativecommons.org/licenses/by/4.0/). 



\title{
Article \\ The Wisdom of and Science behind Indigenous Cultural Practices
}

\author{
Rose Borunda * and Amy Murray \\ College of Education, California State University, Sacramento, CA 95819, USA; amyrosemurray@csus.edu \\ * Correspondence: rborunda@csus.edu
}

Received: 24 September 2018; Accepted: 22 January 2019; Published: 23 January 2019

\begin{abstract}
Conquest and colonization have systematically disrupted the processes by which Indigenous communities of the Americas transmit cultural knowledge and practices from one generation to the next. Even today, the extended arm of conquest and colonization that sustain oppression and culturicide continue to inflict trauma upon Indigenous people. Yet, current scientific research now attests to how Indigenous cultural practices promote healing and well-being within physical as well as mental health domains. This examination addresses Indigenous cultural practices related to storytelling, music, and dance. In drawing from evidence-based research, the case is made for not only restoring these practices where they have been disrupted for Indigenous people but that they have value for all people. The authors recommend reintroducing their use as a means to promote physical, spiritual, and mental well-being while recognizing that these practices originated from and exist for Indigenous people.
\end{abstract}

Keywords: indigenous wisdom; disrupted attachment; cultural restoration; well-being

In our tribal traditions when a woman carried a child, she was protected from anything disruptive such as violence. Everyone in the community ensured that the expectant woman experienced tranquility and calm so that when the child was born, the child would be even tempered and peaceful.

Statement by Connie Reitman-Solas, Pomo

Executive Director, Inter-tribal Council of California CSUS Multicultural Conference, 27 February 2017

\section{Introduction}

Reitman-Solas made this statement at a conference that the authors were co-presenting. This statement is supported by recent epigenetic research. At the time she imparted this cultural practice, I was teaching a graduate level human development class for counselor education students and had just shared a journal article with my class (Douthit and Russotti 2017) that discussed the transaction between biology and environment. The article emphasized how changes in the environment alter our biology and explained how multiple threats undermine physical as well as mental health. The field of epigenetics provided further insight throughout the article and stressed the impact of the environment to the child in the mother's womb. Ultimately, the mother's physiology impacts the unborn child's development which, in turn, has the potential to alter the child's trajectory.

The article confirms that modern-day science has acquired the knowledge and language to describe what the Pomo already knew. The scientific terminology is fetal programming, but it describes an Indigenous Pomo cultural practice. Both modern science and the Pomo encourage us to protect the environment of the expectant mother. Science provides insight to the Pomo cultural practice which yields greater appreciation for the custom. In brief, transmission of the mother's stress hormones 
elevates the risk of the unborn child developing anxiety disorders or attention-deficit/hyperactivity disorder (ADHD). Similarly, if the unborn child is exposed to prenatal famine, a physiological adaptation is set into motion. Subsequently, the unborn child is marked by the (mis)treatment of the mother. This brings us to a greater appreciation for the fact that the Pomo not only knew about the reciprocal relationship between biology and environment, but mindfully incorporated care for the next generation from the moment of conception.

This integrated Pomo cultural practice is but one example of advanced knowledge. What must be considered, however, is that this knowledge is not necessarily available to people outside of the tribe as often oral traditions and customs are only accessible to those still holding the knowledge and passing them on to the next generation. Yet, despite depth of awareness of the transactional nature of biology and environment, disruption to Indigenous culture at the hands of the relentless forces of conquest and colonization have subsumed and deprecated Indigenous knowledge and wisdom. Although initial impact transpired from approximately 150 to about 500 years ago, the persistent denigration of Indigenous cultures and way of life continues to adversely impact the well-being of Indigenous people today (Dunbar-Ortiz 2014; Forbes 2008; Lindsay 2012). Subsequently, cultural practices and knowledge that were transmitted from one generation to the next, which ensured the mental health and well-being of the unborn child at an epigenetic level, have been interrupted and lost in many cases. The unborn child, instead of benefitting from a nurturing, stable and calm environment, is consequently endangered by the adverse effects of the mother's trauma. Once her community is subjected to chronic violent and hostile attacks such as forced relocation, dislocation, acts of genocide, family disruption, and culturicide, the generational pattern reproduces chronic family and community dysfunction (Fenelon 1998).

The authors are both professionally and personally interested in addressing family and community dysfunction due to our background in public education. As educators, the health and wellness disparities in our educational system due to historical processes are evident. Recognizing that the pathways to healing are often situated within the communities that we serve, it is critical to acknowledge and celebrate what we know is of value and of worth. Despite cultural marginalization, the resilience of Indigenous communities gives the next generation a pathway forward if we allow ourselves to recognize and honor practices that have been subsumed over time. The authors are actively engaged with Californian Indigenous communities in promoting Indigenous knowledge and practices not just for Indigenous people but for all of our children in our communities. This restorative experience lends itself to recognizing how cultural practices can promote healing between people who have been historically in conflict.

Exposure to external and persistent threats changes the nature of relationships within a community. Where there may have been practices that maintained cohesive, peaceful, and deeply rooted ways of being, these practices become secondary when outside pressures force change. Harmony with oneself, one's community, family, and with the environment are disrupted. The energy that was once directed toward sustaining harmonious and reciprocal ways of life is re-directed by the necessity to make survival the primary focus. This shift for individuals and communities who have experienced historic trauma potentially has long-term adverse implications which can be viewed from a human development perspective:

If an organism is stuck in survival mode, its energies are focused on fighting off unseen enemies, which leaves no room for nurture, care, and love. For us humans, it means that as long as the mind is defending itself against invisible assaults, our closest bonds are threatened, along with our ability to imagine, plan, play, learn, and pay attention to other people's needs. (Van der Kolk 2014, p. 76)

For the Pomo and for all the other American Indigenous nations, adaptation to a hostile world has been necessary in order to ensure survival. However, this does not mean that the cultural wisdom that sustained community, familial, and individual well-being and cohesiveness are completely annihilated. It is often assumed that Indigenous nations no longer exist. Often, they are completely omitted from 
the historical narrative (Reclaiming Native Truth 2018) and if referred to, they are often spoken about in the past tense (Roscoe 1991). Yet, many Indigenous cultural practices that sustain mental, physical, and spiritual health have survived, are embodied, and still practiced today. Embraced by Indigenous mental health professionals and critical scholars (Duran et al. 2008), there is a direction toward holistic practices that address spiritual needs. Subsequently, as we revisit Reitman-Solas's statement and widen our focus to identify these practices, we can recapture and restore the holistic wisdom inherent in Indigenous cultures. This wisdom has value in the modern era where appreciation for such practices has been lost, and in many cases, forcibly eliminated.

While Western science uncovers and comes to appreciate what was already known and practiced by America's Indigenous people, the adverse impact of trauma upon Indigenous communities, the land, the environment, and to the unborn child continues to resonate. For this reason, it is critical to reclaim and understand the benefits of Indigenous practices and sensibilities that instill resilience, recovery, and the holistic restoration of a healthy environment into which the unborn child enters. To this end, this manuscript explores a sampling of cultural practices rooted in various Original Nations from the Americas. These practices examine the contexts of storytelling, music, and dance while acknowledging the inter-relationship with modern day science. Ultimately, where historical disruption has created harm at the individual, generational, and community levels, restoration of proven practices can reverse the damage inflicted on Indigenous communities and still be of value for non-indigenous populations as well. This value is now being corroborated by Western science.

\section{Western Nouveau Science}

Evidence-based scientific research corroborates the biological and psychological benefits of Indigenous cultural practices. This survey provides scientific substantiation of Indigenous cultural practices for several reasons. Yet, before discussing science, it is important to note that Indigenous practices do not require scientific validation. For those living and practicing their culture, the worth of these practices is self-evident and does not require external validation. Instead, recognition of the inherent wisdom of Indigenous cultural practices is vital due to the fact that: (1) the value of the practices and their capacity to promote cohesion and well-being have gone unrecognized; (2) Indigenous cultures have been denigrated and subsequently misunderstood, which calls for a correction of false portrayals; and (3) the wisdom embedded in Indigenous cultures is as valuable today and for the future as it was in the past. With an understanding and appreciation for the benefits of these practices, there is cause for restoring and maintaining well-being from the personal to the community level.

Mental health and medical practitioners recognize trauma and the multi-generational transmission of trauma as a major issue. The landmark study known as the Adverse Childhood Experiences (ACE), first conducted between 1995 and 1997, demonstrated how stressful traumatic childhood experiences lead to chronic health challenges. These traumatic childhood experiences include abuse, neglect, and household dysfunction such as witnessing domestic violence or growing up with family members who have substance use disorders. Inclusively, these developmental threats may lead to a wide range of health problems throughout a person's lifespan, including those associated with substance misuse, and also have the potential of being re-transmitted from one generation to the next (Van der Kolk 2014).

Disrupted attachments, as one of the adverse outcomes of historic trauma, calls for optimal approaches that are not only strengths-based but culturally responsive. To this end, Canadian Professors Haskell and Randall (2009) acknowledge the importance of employing traditional as well as modern day approaches:

An approach which deeply engages both the knowledge and insights gleaned from the developments in the research on neurobiology, neuroscience, attachment theory, and developmental psychology, with the wisdom and traditional aboriginal approaches to mental health, can only be a richer one. (Haskell and Randall 2009, p. 91) 
This standpoint respects the practices of Indigenous people that were intact before wide-scale conquest and colonization hit the Americas. It also recognizes that, when and wherever possible, we can recapture and apply healing approaches for people today who continue to experience assaults upon their well-being. It is also acknowledged that enculturation, the "socialization process through which individuals learn and acquire the cultural and psychological qualities of their own group" (Erford and Hays 2018, p. 6) is an active process. Mental health practitioners and Indigenous community leaders can collaboratively pursue ways to restore and maintain harmony in communities into which future generations are received.

To this end, author Gloria Bird (Ortiz 1998) addresses the pain inflicted upon Native people raised on reservations. She also provides insight regarding how to move beyond victimhood and suggests that people "... focus less on the perceived pain that has been handed down through the generations and more on the larger issue of decolonization of the mind that comes with identifying the source of the pain in order to be free of its power over us" (Ortiz 1998, p. 30). The emphasis is on developing critical understanding of what has transpired over the course of the last 500+ years to invoke psychological liberation. In doing so, the "ability to imagine, plan, play, learn, and pay attention to other people's needs" is heightened, which then improves one's ability to constructively engage with the world (Van der Kolk 2014, p. 76). It is for this reason that we recognize and honor Indigenous knowledge, starting with the traditional wisdom cultural practices in order to maintain the long term well-being of Indigenous communities.

\section{Honoring Traditional Wisdom}

Cultural invasion (Freire 2018) enacted upon the people of the Americas has attempted to psychologically subjugate people when and where conquest and relocation did not succeed in its effort to accomplish absolute genocide. In the attempts to subjugate and conquer Indigenous communities, "the assumed inferiority of American Indians has perpetuated negative stereotypes and images to those who have come to call the United States their home" (Borunda and Martinez-Alire 2014, p. 31). Subsequently, if a community lacks personal, material, cultural and social resources, its capacity to constructively respond to trauma and its lingering impact may be compromised (Collins and Collins 2005). Recognizing that intergenerational trauma is "the effects of and responses to traumatic events (which) can become 'transmitted' across generations" (Haskell and Randall 2009, p. 52), the absence of protective resources that buffer the damage from traumatic events increases the potential for self-destructive behavior. Similarly, horizontal violence, harm enacted upon one's own families and community, can become a debilitating statistical reality (Freire 2018).

Fortunately, not all was lost during the sustained efforts to eradicate and subjugate Indigenous communities. Many Indigenous cultures endeavored to form and sustain collective identities whose existence would endure the challenges of time (Florescano 1999). This resilience was sustained by the singular goal of ensuring survival of the collective by passing down practices and knowledge as an inheritance to future generations. These practices were intended to not only sustain Indigenous collective identity, but also to foster continuity. The multiple means by which this generational transmission took place is testament to the prescience of Indigenous elders:

To transmit the messages of one group to others, the ancients invented a variety of languages. The physical, oral, and visual were the first languages to transmit the collective experiences, and the means most efficacious to pass on the acquired knowledge for the generations to come. The initial forms of written language came about centuries much later, barely 500 years ago. (Florescano 1999, pp. 13-14)

Traditional knowledge was, thus, sustained by a variety of communication systems, not restricted to one means. These systems consist of physical language as evident in dance, and by the use of oral traditions in which stories are shared over the generations. They also include the varied sounds of 
music that promote healing and bond humanity through rhythms, harmonies, and melodies. These communications convey not only what a people have experienced and endured, but also transmit embedded lessons and narratives that guide future generations.

Finally, ceremonies and rituals were, and in many cases, continue to be conducted at sacred sites that were constructed or identified in natural surroundings. These ceremonies provide a collective experience and identity that is grounded in time and place. In acknowledging the multiple languages by which Indigenous cultures embedded their cultural values, while simultaneously recognizing the scientific rationale behind the cultural practices, we develop insight. This insight leads us to understand, appreciate, and learn from the wisdom of Indigenous ancestors who left a rich legacy for future generations including the practice of storytelling that will be elucidated in the next section.

\section{Restoring Culture and Affirming Identity through Oral Tradition}

Silko (as cited in Ortiz 1998) describes how Pueblo people transmitted culture through storytelling. In a chapter entitled, "Through the Stories We Hear Who We Are", she explains Pueblo practices:

... depended upon collective memory through successive generations to maintain and transmit an entire culture, a worldview complete with proven strategies for survival. The oral narrative, or story, became the medium through which the complex of Pueblo knowledge and belief was maintained ... everyone, from the youngest child to the oldest person, was expected to listen and be able to recall or tell a portion of, if only a small detail from, a narrative account or story. Thus, the remembering and the retelling were a communal process. (Ortiz 1998, pp. 8-9)

Similarly, the Mexica (also known as Aztec), are known for highly valuing children. They invested in their children because they believed that doing so was the optimal way to live beyond one's lifetime. For this reason, children were provided an education that emphasized "respect for all people and things, self-discipline, self-knowledge and fulfilling one's tonalli, or destiny, were the key points of traditional Aztec schooling" (Mini 2000, p. 82). Subsequently, educating children was one of the main ways to demonstrate care and deep appreciation for the next generation. Ensuring the well-being and stability of their culture meant specifying and controlling the narrative conveyed from one generation to the next, so that children would value and live in a harmonious relationship with themselves and with their community.

Fortunately, we already have excellent examples of how Indigenous people have employed the use of narrative for the purpose of protecting their psychological well-being, as well as differentiating their own set of values from those of the colonizers. The prolific trickster stories from the Spanish colonial era in Mexico depict humorous accounts in which the impoverished protagonist, Pedro de Ordimalas, uses his wit to outsmart greedy and mean-spirited outsiders who fall for any scheme that involves getting rich. These stories are just as relevant today in conveying adaptive strategies for survival and resilience in the aftermath of conquest and colonization. Within these narratives children learn that wit is vital for survival and that a life guided by materialism is vapid, short-sighted, and undesirable. In the end, they learn that intelligence and a life free of possessions, like that of Pedro, is superior to that of the colonizer (Vigil 2000). The stories teach the value of a life grounded in respect for self and for community, and also convey that materialism and greed are undesirable and culturally incongruent. Despite the passage of time, these post-conquest era stories can now be found in print and can be shared with the next generation for the purpose of restoring cultural values where historic disruption has broken the chain of oral tradition.

In addition to the sharing the stories that have survived cultural disruption and have found their way to the printed word, there is a range of mediums by which to repair the broken processes in which cultural values and traditions are transmitted. Johnson (2014) indicates four ways in which the Ojibwe people are working to restore their culture: 
Traditionally, Ojibwe people passed on their cultural traditions orally to encourage the individual's spiritual, intellectual, physical, and emotional growth from one generation to the next. One way to restore some of the cultural ways in an informal setting is by home-based schooling, when the parents teach their children. Another way is one-on-one transmission through mentoring activities, passing on traditional skills by sharing knowledge in arts, crafts, hunting, fishing, and medicine. Another way is the interactive talking circle, a small group where people can share and process healing in traditional ways. A more formal way of learning traditional ways is by attending conferences or workshops, attending traditional institutions, and attending some of the community cultural events like powwows, community feasts, and art shows. (Johnson 2014, p. 22)

The stories and narratives that affirm positive identity and proper humanistic values are in our midst. Concerted efforts to restore the lines of communication that promote well-being could be strategically placed in order counter the debilitating messages given by those who propagate divisive and debilitating rhetoric. Additionally, the power of the pen, when in the hands of Indigenous authors, can wield tremendous strength and buttress resilience. For example, Yazzie (2014) first novel, 'Her Land, Her Love,' weaves cultural lessons into the story. While the reader follows the life of Ninááníbaá, a woman whose family suffers but survives the Navajo Long Walk of 1865, critical lessons are shared throughout the novel, as in the following excerpt:

Ninááníbaá remembered back to an early age, when she was taught to be careful of the words she spoke. She learned to be deliberate in her speech at all times. Words were never spoken to hurt another person. A person should only speak words that are good. It is useless to speak words that hurt, were the teachings Ninááníbaá heard all through her young life. If someone voiced an expression out of meanness, the Naabeehó elders were close by, weighing the words spoken, and a long lecture by the elders followed a mean or angry statement. (Yazzie 2014, p. 27)

This culturally imbedded lesson from the Diné, also known as the Navajo, conveys how we are to speak to one another (and how we are not to speak to one another). It guides the nature of community relationships by establishing and then reinforcing the manner in which people are expected to communicate. The scientific support for this vital practice is discussed by Van der Kolk (2014), who explains the impact of insults from a neurobiological framework: "We remember insults and injuries best: The adrenaline that we secrete to defend against potential threats helps to engrave those incidents into our minds. Even if the content of the remark fades, our dislike for the person who made it usually persists" (Van der Kolk 2014, p. 176).

The aforementioned Diné lesson provides valuable wisdom that is of relevance today, as continuous insults are hurled from the person occupying the highest elected office in the United States and unrestrained abusive language is shared by preteens and adults alike on social media. Such insults stamp a neurological imprint on the receiver, creating a dissonance that collectively pollutes and impedes our capacity to live in harmony and in good relations with one another. Yet, the Diné and other Indigenous communities recognize and value the importance of weighing one's words before delivering them to the world. With acknowledgement and strategic restoration of these lessons and narratives, families and communities have the potential to rebuild and strengthen the next generation's resilience to outside threats.

Narrative therapy, one of many counseling approaches employed by psychotherapists today, "assumes that culture, language, relationships and society contribute to the way that individuals understand their identities and problems and make meaning in their lives" (Phillips 2017, p. 27). This approach recognizes that the narrative which a community conveys to its children is vital to their well-being and sense of identity. Thus, it is disconcerting when the culturally proscribed narrative has been usurped and maligned because doing so causes adverse impacts on the individual, the community, and subsequent generations. This has been the case in the Americas as colonizers have summarily 
manipulated and conveyed a psychologically damaging narrative in order to control Indigenous people. In losing control of the narrative, Indigenous people are subsumed in a reality that is not only demoralizing, but that propagates divisive and destructive behaviors within that reality (Borunda and Moreno 2014).

Fortunately, the language of music provides an alternative form of communication by which to seek balance and well-being.

\section{Music as Medicine}

The Mayan story entitled "The Murmur of the River, How Music Came to the World" tells how the Mayan gods knew that "their creation of Earth and people would forever be unfinished if the people never had music in their hearts. Music would help the people of the Earth to remain joyful throughout the hardships of life" (Vigil 2000, p. 66). To correct the absence of music, the god Ah Kin Xooc was given a sound by each god who had contributed in the creation of the Earth. The collected sounds were "the sound of lament, the sound of complaint, the sound of truth, the sound of forgiveness, and the sound of joy" (Vigil 2000, p. 66). The story indicates that these sounds were released upon Earth and brought joy and sadness to the hearts of the people. In turn, the people were so moved by the profound beauty of the sounds that they took it upon themselves to make instruments that imitated the sounds and, from that point on, were able to make their own music.

A key feature of this story speaks to the gods giving people music for "the heart" and of music serving as a means by which to overcome "hardships." In essence, this conveys an understanding that music has healing properties that are beneficial for addressing physiological and emotional contexts. This understanding is recognized, today, as a profession called music therapy (Levitin 2013). Yet, for thousands of years, Indigenous cultures have incorporated music in their rituals and ceremonies (Densmore 1926) with one of the primary instruments used by Indigenous cultures being the flute.

Wiand's doctoral study (Wiand 2001) not only highlighted the historical background and uses of the Native American flute but she studied the healing effects of the Native American flute for people diagnosed as having dissociative disorders. The researcher describes this disorder as "a process of dis-association of parts of the self from the self ... a defense against remembering the overwhelming trauma and its related affects" (Wiand 2001, p. 1). Wiand discusses the impetus for employing music in addressing this particular disorder:

Music has been used for "healing" since the beginnings of recorded history. On the most basic level, it is used to promote a state of relaxation. In ancient spiritual traditions and in shamanism, which is believed to be one of the oldest known forms of healing, music is used to access altered states of consciousness (i.e., trance states) to facilitate "healing". (Wiand 2001, p. 2)

Wiand (2001) ascertains that Native American tradition possesses a cosmological view that recognizes the healing properties of music in restoring balance and wholeness to individuals. Music restores wholeness to those who have experienced a fragmentation, and subsequent disassociation, from themselves. The application of sacred sound to the disassociated individual embraces traditional knowledge that recognizes energy from sound as a flow that can restore harmony and balance within the body and the soul. In applying this foundational understanding to her study, Wiand confirmed what Native Americans have known for thousands of years.

In brief, Wiand's study focused on two groups of people, one group consisted of individuals diagnosed with dissociative disorder and the other without such a diagnosis. Within these groups, some were exposed to either Native American flute or they were exposed to placebo music. Those who heard the Native American flute reported reduced anxiety, a significantly greater increase in perceptions of interconnectedness, and an increase in universal interconnectedness. These results confirm the significance of a cultural practice that is only now being recognized by modern science. 
Similarly, a plethora of studies (Levitin 2013; Armstrong 2016) speak to how music travels through neural pathways and activates various sections of the brain. Whether it is a pleasurable melody or engaging rhythm, there is a correlated response that releases endogenous opioids such as dopamine or prolactin into the body. Given these biological benefits we can understand not only why there is a recognized field called music therapy but also its impact. Wiand (2001) confirms the healing aspects of one of the oldest instruments in the world, explaining, "It is being rediscovered by the medical and psychological communities what the spiritual and ancient cultures have known all along, that music and sound do in fact have a significant impact on the physical, emotional, and spiritual aspects of the individual" (Wiand 2001, p. 22).

While music, in general, and the Native American flute, in particular, possess qualities that promote healing, the concerted use of music for individual and community connectedness has far-reaching implications. Where such practices have been disrupted the sounds can be restored. In line with the concept of restoring human bonds with one another within a community context, the following section elaborates on another cultural practice that promotes collective healing.

\section{The Power of Movement/Dance}

Luna (2011) examines how Danza, the sacred-ceremonial Mexica (also known as Aztec) dance, serves as a cultural product that maintains Indigenous identity of Xicano/a people throughout the Americas. The affirmation and protection of Indigenous identity is critical as the forces of assimilation attempt to denigrate and strip the uniqueness of Indigenous cultures. She explains how the healing properties of this physically artistic and spiritual expression asserts "self-determination as the cornerstone of decolonization" (Luna 2011, p. 7). Luna indicates that the performance of Danza, similar to Indigenous dances across the continent that have been carried on for hundreds of years "creates a living, on-going connection to history, demonstrating to students that we exist" (Luna 2011, p. 10). In this cultural practice, the repetition of the ceremonies, rituals, and movement by generations of Indigenous people across the continent affirms a meaningful connection to those no longer here and to those yet to come. These expressions provide a sense of rootedness for the dancers while also giving life and meaning to future generations who follow the same steps of those before them.

Luna recounts her own experience with the first time she attended a Danza practice. She describes the moment in which she was "hearing the drum" which drew her to the circle of dancers and "feeling a need to be there, as if it was where I had always belonged" (Luna 2011, p. 17). This calling to be a part of a collective experience in which movement, sound, ceremony, and ritual are dominant features is described as a manifestation of "genetic memory" (Esteva and Prakash 1998), a feeling shared by other danzantes in which being near the drum becomes the central force.

In Danza, as in many other Indigenous cultures that still engage their communities in collective movement, science is not separate from the practice. For example, the traditions from which Danza emanates is described as a "complex philosophical belief and practice" and serves as a "religion" (or spirituality). In doing so, science and spirituality are not separate but are, instead, viewed holistically in a collective experience that incorporates mind, body, and spirit. Within this holistic and ceremonial experience, highly mathematical and calculated dance steps are infused with scientific meaning and metaphor, meant to both imitate and affect the natural world while telling stories that explain natural phenomena. Luna describes the richness imbedded in Danza as "movement and human expression of natural and cosmic phenomena, creating consciousness and a connection between participants themselves and with the delicate balance, equilibrium, and harmony of the Earth and universe" (Luna 2011, p. 89).

With this description of the multi-layered meaning behind Danza we could similarly apply its benefits to the culturally grounded dancing of many Indigenous communities. As such, the implications of Danza and other such culturally grounded movements in the mental health field are apparent. In the treatment of post-traumatic stress disorder, movement is recognized as 
one of three "bottom-up" approaches, and is recommended in regulating the amygdala, the emotional center of the brain. The other two approaches consist of touch and sound.

The explanation for how movement addresses emotional states is addressed by understanding the mind and body connection. When an individual has experienced but not processed an inflicted external harm, their sense of safety is compromised. Consequently, this heightened state of threat can precipitate the emotional center to overreact to perceived threats. When the amygdala is engaged through movement, the symptoms to the perceived threat are minimized. In the collective experience of culturally sanctioned dancing, the positive associations that include human connection and community engagement become apparent (Van der Kolk 2014).

Danza, as a living embodiment of culture and relationship, is further described by Luna (2011) as a ritual performance that employs all the senses and makes manifest the memory of a people. This, in turn, creates meaning and purpose. Luna also provides further perspective about Danza that underscores the scientific meaning and purpose for the practice, "Once one learns the dances, they no longer have to recall the steps or patterns. The memory is in the body and the dance becomes a meditation" (Luna 2011, p. 94). With access to this bottom-up approach, the body's stress responses are regulated in a holistic, as well as culturally responsive and identity affirming practice.

\section{Conclusions}

Multiple elements of Indigenous cultures have been discussed in this manuscript for their wisdom in restoring well-being. Scientific analysis further explains how these practices address the physical and mental health of individuals and communities, which validates the application of these practices in the modern era. In the face of historic disruption where these practices no longer exist, the recognition that the web can be repaired is vital in restoring cultural values and integrity. These practices have far-reaching implications for both people of Indigenous identity and for all those who lack connection to self, to community, and to the Earth. They are valuable lessons for all of us who now call this land home.

As we revisit Reitman-Solas' statement, we see how mindful consideration of how we relate to even the unborn child has generational and far-reaching impact. The wisdom inherent within Indigenous cultures existing in our midst contain opportunities to heal trauma and sustain well-being. In doing so, focused teachings can be revived as we look to generate a healthy and vibrant society. While the contexts of storytelling, music and dance were discussed and supported with their application in the here and now, there is much more that can be recaptured in our quest to promote well-being. Considering that these three practices, from a holistic perspective, are interrelated by virtue of their capacity to redefine a person's connectedness with self and with others, the strength of their overlapping impact is undeniable and powerful. Future generations depend not only on our awareness that this wisdom exists but depend on our active commitment to the restoration and sharing of Indigenous cultural practices.

Author Contributions: Writing, reviewing and editing, R.S. and A.M.

Funding: This research received no external funding.

Conflicts of Interest: The authors declare no conflict of interest.

\section{References}

Armstrong, Courtney. 2016. Music: A Powerful Ally in Your Counseling Sessions. Available online: https:/ / ct.counseling.org/2016/02/music-a-powerful-ally-in-your-counseling-sessions /\# (accessed on 19 September 2018).

Borunda, Rose, and Crystal Martinez-Alire. 2014. Integrating First Nation's Knowledge and Orientations; a Conceptual Model toward Equity and Educational Advancement. Journal of Transformative Leadership and Policy Studies 4: 31. 
Borunda, Rose, and Melissa Moreno. 2014. Speaking from the Heart: Herstories of Chicana, Latina and Amerindian Women. Dubuque: Kendall Hunt.

Collins, Barbara G., and Thomas M. Collins. 2005. Crisis and Trauma: Developmental-Ecological Intervention. Boston: Cengage Learning.

Densmore, Frances. 1926. The American Indians and Their Music. New York: Johnson Reprint Corp.

Douthit, Kathryn, and Justin Russotti. 2017. Understanding Fetal Programming to Promote Prevention and Wellness Counseling. Counseling Today 59: 16-20.

Dunbar-Ortiz, Roxanne. 2014. An Indigenous People's History of the United States. Boston: Beacon Press.

Duran, Eduardo, Judith Firehammer, and John Gonzalez. 2008. Liberation Psychology as the Path toward Healing Cultural Soul Wounds. Journal of Counseling \& Development 86: 288-95. [CrossRef]

Erford, Bradley T., and Danica G. Hays. 2018. Developing Multicultural Counseling Competence, 3rd ed. New York: Pearson Press.

Esteva, Gustavo, and Madhu Suri Prakash. 1998. Grassroots Post-Modernism. New York: Books Ltd.

Fenelon, James V. 1998. Culturicide, Resistance, and Survival of the Lakota. New York: Garland Publishing.

Florescano, Enrique. 1999. Memoria Indígena. Compton: Santillana.

Forbes, Jack. 2008. Columbus and Other Cannibals. New York: Seven Stories Press.

Freire, Paulo. 2018. Pedagogy of the Oppressed. New York: Bloomsbury Publishing.

Haskell, Lori, and Melanie Randall. 2009. Disrupted attachments: A Social Context Complex Trauma Framework and the Lives of Aboriginal Peoples in Canada. Journal de la Sante Autochtone 5: 48-99.

Johnson, Carol. 2014. Native American Spirituality and Healing in a Euro-American World. Available online: https://sophia.stkate.edu/msw_papers/340/ (accessed on 19 September 2018).

Levitin, Daniel J. 2013. Neural Correlates of Musical Behaviors a Brief Overview. Music Therapy Association 31: 15-24. [CrossRef]

Lindsay, Brendan C. 2012. Murder State: California's Native American Genocide 1846-1873. Lincoln: University of Nebraska Press.

Luna, Jennie M. 2011. Danza Mexica: Indigenous Identity, Spirituality, Activism, and Performance. Ph.D. dissertation, San Jose State University, San Jose, CA, USA.

Mini, John. 2000. The Aztec Virgin. Sausalito: Trans-Hyperborean Institute of Science.

Ortiz, Simon J. 1998. Speaking for the Generations: Native Writers on Writing. Tucson: University of Arizona Press.

Phillips, Lindsey. 2017. Stories of Empowerment. Available online: https://ct.counseling.org/2017/09/stories-ofempowerment/ (accessed on 19 September 2018).

Reclaiming Native Truth. 2018. Changing the Narrative about Native Americans: A Guide for Allies. Available online: https:/ /www.reclaimingnativetruth.com/wp-content/uploads/2018/06/MessageGuideAllies-screen.pdf (accessed on 19 September 2018).

Roscoe, Will. 1991. The Zuni Man-Woman. Albuquerque: University of New Mexico Press.

Van der Kolk, Bessel. 2014. The Body Keeps the Score: Integration of Mind, Brain, and Body in the Healing of Trauma. New York: Viking.

Vigil, Angel. 2000. The Eagle on the Cactus: Traditional Stories from Mexico. Englewood: Libraries Unlimited.

Wiand, Lenore. 2001. The Effects of a Sacred/Shamanic Music on Trauma-Related Disorders: Dissociative Disorders and Music of an Indigenous Native American Flute. Ph.D. dissertation, University of Detroit, Detroit, MI, USA. Available online: http://journals.sfu.ca/seemj/index.php/seemj/article/view/48/38 (accessed on 19 September 2018).

Yazzie, Evangeline. 2014. Her Land, Her Love. Flagstaff: Salina Bookshelf, Inc.

(C) 2019 by the authors. Licensee MDPI, Basel, Switzerland. This article is an open access article distributed under the terms and conditions of the Creative Commons Attribution (CC BY) license (http:/ / creativecommons.org/licenses/by/4.0/). 
Article

\title{
Transgenerational Transmission of Holocaust Trauma and Its Expressions in Literature
}

\author{
Bina Nir \\ Department of Communication, Honors B.A Program, The Academic College of Emek Yezrael, \\ Yezrael Valley 1930600, Israel; binan@yvc.ac.il; Tel.: +972-50-649898
}

Received: 24 September 2018; Accepted: 14 November 2018; Published: 19 November 2018

\begin{abstract}
Trauma is a central concept in the historiography of the Holocaust. In both the historiographical and the psychoanalytical research on the subject, the Holocaust is perceived not as a finite event that took place in the past, but as one that continues to exist and to affect the families of survivors and the Jewish people. In the 1950s-1960s, evidence began emerging that Holocaust trauma was not limited to the survivors themselves, but was passed on to the next generation born after the Holocaust and raised in its shadow. It is possible to see the effects of growing up in the shadow of the Holocaust and transgenerational transmission of trauma in many aspects of the second-generation children's lives. In this article, I examine the representations of these symptoms in David Grossman's novel See Under: Love, which deals with the subject of the Holocaust through the perspective of Momik, a child of Holocaust survivors. Grossman teaches us that writing itself has the potential to heal. He also shows us that every one of us contains both victim and aggressor, and that, under certain circumstances, the "Nazi beast" may awaken within each of us.
\end{abstract}

Keywords: Holocaust; survivors; second generation; transgenerational transmission; trauma; Grossman

\section{Introduction}

The word trauma originates from Greek, meaning "wound" or "injury". In cultural discourse, the word is used as a metaphor for a hidden psychological wound (Arev and Gurevitch 2012, p. 452). "Trauma" is a state in which a person suffered psychological harm following a single experience or a series of experiences that are perceived as particularly grievous. The deciding factor that makes an experience traumatic is a person's ability to deal with the event emotionally. Traumatic experience is subjective and differs from person to person, but among the various factors that are considered conducive to trauma, one always finds a real and significant experience of fear, helplessness, loss of control, and threat of annihilation — a state in which a person feels that their life, physical integrity, or mental integrity is in danger. Trauma is the persistent presence of malaise that remains even after the threat has passed (Herman 2015, pp. 34-35; Perry 2007). It is often described as an out-of-body experience, as something that is not happening to the person him- or herself. This dissociation from the traumatic reality and its memory is accompanied by a series of disconnected images that lack context and continuity, and may also manifest itself as a feeling of time passing in slow motion (Herman 2015, pp. 34-35). Since the event is not fully experienced in real time, it is doomed to never be fully known and is, therefore, compulsively relived by the traumatized psyche. The memories such an experience creates are powerful and crystalized—they are not given to change, even with the passing of time (Amir 2018, pp. 9-10).

Trauma is a central concept in the historiography of the Holocaust. In both the historiographical and the psychoanalytical research on the subject, the Holocaust is perceived not as a finite event that took place in the past, but as one that continues to exist and to affect the families of survivors, 
the Jewish people, and Israeli society (Ben-Dat 2015, p. 30). The aftermath of this trauma can be identified in the public, political, and cultural discourse, as well as in the artistic discourse across the various media of expression. The catastrophe experienced by European Jews still resounds powerfully in the collective memory and is a major subject of study across a variety of disciplines. The Holocaust was a massacre of inconceivable cruelty and magnitude, a traumatic event of enormous scope and immeasurable repercussions and, therefore, it is impossible to think of the Holocaust within the temporal framework of 1933-1945 alone (Bauer 1978, p. 92). With the liberation of the concentration camps, most of those who managed to survive this hell on earth immigrated either to the United States or to Israel, and tried building a new life while still in a state of physical and mental devastation, having lost their families and everything they had. Many among the survivors suffered traumatic experiences of various degrees, and many even developed post-traumatic stress disorder in the years after the war, due to the prolonged duration of their trauma (Steier 2009, p. 148).

Post-traumatic stress disorder (PTSD) is a psychiatric condition of the kind that arises due to the trauma and stress caused by an event that jeopardized the individual's physical and mental integrity. Post-trauma is most often accompanied by feelings of fear, anxiety, and helplessness, as well as intrusive memories of the event, efforts to avoid anything that might evoke the event, constant alertness, and difficulties achieving relaxation. The combined effect of all or some of the above can result in severe impediments to the individual's ability to lead a normal life after the traumatic event. Trauma breaks through our self-defense systems and, in its aftermath, the individual may experience apathy, emotional distance, aversion to change, and diminished contact with the world (Ben-Dat 2015). According to several reports, survivors who settled in Israel after the war exhibited fewer pathological symptoms than those who immigrated to North America (Hass 1996, p. 15). It is possible that they saw their rebirth and rehabilitation as part of the foundation and growth of the State of Israel. It must also be noted that the State of Israel provides opportunities to work through grief with special commemoration programs, public days of remembrance, and more. Nevertheless, along with ongoing trauma and a diminished self-image, many of the Holocaust survivors who immigrated to Israel had to endure neglect and degradation at the hands of the caretaker community (Steier 2009), as well as condescension from Jews who immigrated to Israel before the 1930s and who, therefore, had not lived through the Holocaust. They were socially pressured to forget about their past and to draw a line between the "here and now" of Israel and the "there and then" of the Holocaust (Shapira 1992, p. 455).

Starting from the 1950s and 1960s, evidence began emerging that the Holocaust trauma and its after-effects were not limited to the survivors themselves, but were passed on to their children, also called the "second generation" (Kellermann 2008). The term "second generation" refers to the children of Holocaust survivors who were born after the great cataclysm and grew up in its shadow. The prevailing research assumption is that this group was significantly affected by the traumas their parents experienced during the Holocaust, from birth and throughout their lives, and that, even though members of the "second generation"1 did not directly experience the Holocaust, they exhibit identifiable symptoms and influences of the trauma their parents suffered in various aspects and phases of their lives (Berger and Ivgi 2009). In the 1960s, several clinicians claimed that children of survivors made up a relatively large percentage of all adolescents receiving psychiatric care (Rakoff et al. 1966, pp. 24-26). Children of survivors differ, of course, from one another in personality types, in their level of achievement, and in their lifestyles. Any generalization made about this group is inherently problematic. However, research shows that, despite the variance in their

1 The author, Bina Nir, is the daughter of parents who underwent Nazi persecution and experienced trauma during the war, as well as PTSD after the war. Her father lost his entire family in the war, including parents, four brothers, grandparents, and uncles. Throughout her childhood, Bina's father was prone to depression, listlessness, and utter silence in regards to anything remotely related to the Holocaust or his family. She was named after her aunt, her mother's sister, who perished at the age of 22 in a transit camp toward the end of the war. 
characters and ways of adapting to their environment, certain issues stand out for many of them (Barocas 1973, pp. 820-21; Russel 1974; Hass 1996).

This statement must be qualified by mentioning that the assortment of disorders attributed to "the second generation", which we will describe in detail further on, are mostly non-pathological and are considered within the range of normal behavior; however, they are still thought to be disorders particular to this generation (Aviad-Wilcheck and Cohenca 2011). Vardi calls the members of the second generation "yahrzeit candles" or "bearers of the mark", living memorial candles in honor of those killed in the war (Vardi 1990). In her eyes, members of the second generation absorbed and were influenced by the aura of death that surrounded their parents and, therefore, the motif of death and identification with death became a central component of many second-generation members' personalities.

In this paper, I focus on members of the second generation who were born and raised in Israel. Today, this generation is also approaching old age, and many among them are parents to third-generation survivors and grandparents to fourth-generation survivors. The effects of growing up in the shadow of the Holocaust and its trauma, passed down from survivor parents to their children, can be identified in a variety of facets of the second-generation members' lives. I examine, in this article, the expressions of these symptoms as they are reflected in the behavior of the protagonist in David Grossman's novel See Under: Love.

The novel tells the story of a couple of Holocaust survivors who went through the horrors of the death camps along with their son (the second generation); they deal with the influence of the Holocaust trauma and its effects on the children of the survivors. In this article, the novel serves as a case study to examine the atmosphere surrounding the children of the survivors during the 1950s in the State of Israel. Although the novel is not a documentary testimony but a fiction written by the award-winning writer Grossman, I would like to learn through it about the cultural and social atmosphere of that period, the first generation's coping with the subject of parenthood, and the effects of their trauma on their children-the second generation. Fiction literature writings on this sensitive subject have a dimension of therapy for both the writer and the readers. This novel also legitimized Holocaust survivors and their children to experience openly and not to hide their great pain, especially at a time when Israeli society did not show much tolerance. In addition, the writer's attitude toward the victim and the aggressor has an important contribution to the social dialog.

Humans are natural story tellers-they construct and reflect their personal and social reality through narratives, and thereby sometimes indirectly manage to influence the reality of those who read them (Shakedi 2003). There are books that, in order to love them or identify with them, require the reader to be familiar with the era out of which they emerged, with the prevailing zeitgeist and fashions of the time; and there are books that are independent of their time, that are self-sufficient (Dingut 1986). Literature is a journey of self-discovery, a constantly shifting, dynamic relationship between the individual and the society, culture, and context in which they operate. Literature can be viewed as a dialog or a discussion between the readership, the discourse, and the work itself (Foiss 2006).

Writers have the ability to experience intensively and identify with the psychological impressions of their environment, and to transmit them with refined vigor that is often stronger than the stories of those who actually experienced them. The writer is not committed to the facts and accurate documentation, but to the impact he wants to create in the reader's mind. The special ability of the writer Grossman to empower deep psychological experiences, difficult to describe and understand, is expressed in the creation of an exaggerated literary character that contains disorders that may belong to more than one authentic person that characterizes the second-generation Holocaust survivors. Such a figure serves in my article as a broad platform for understanding, identifying, and applying psychological theories concerning the problems of the second generation. 


\section{Transgenerational Transmission and Holocaust Trauma}

Many researchers adopted the assumption that the transmission of pathology from survivors to their children is unavoidable (Kestenberg 1972). The term "transgenerational transmission" is usually used to describe the tendency of parents to recreate in their relationships with their children parenting patterns experienced in early childhood-patterns that can be predominantly positive or negative, and have to do with the quality of attachment between parent and infant, as well as the caregiving behaviors that characterized it. Nevertheless, an external traumatic event can also open the door to transgenerational transmission, even in later stages, after early infancy. Researches differentiate between two patterns of transgenerational transmission of Holocaust trauma from survivors to their children (Sigal and Weinfeld 1989; Felsen 1998). The first of these is "direct transmission", referring to a pathological mental syndrome (e.g., schizophrenia, paranoia, depression, anxiety, etc.) that manifested in the survivor parent following his or her experiences during the Holocaust, and which was also identified in the child. The second kind of possible transgenerational transmission is "indirect transmission", which is also the prevalent kind. With indirect transmission, a disorder suffered by the parent due to his or her experiences in the Holocaust leads to significant difficulties in his or her functioning as a parent, which leads to an overall feeling of neglect or deprivation on the part of the child. Post-traumatic stress can also be passed on from parent to child through the process of transgenerational transmission (Baranowsky et al. 1998). There are several different approaches to explain the way in which transgenerational transmission of Holocaust trauma occurs.

\subsection{The Psycho-Dynamic Approach}

This approach explains transgenerational transmission of Holocaust trauma as an unconscious process whereby the child over-identifies with his or her post-traumatic parents, leading to a process of internalization that sometimes results in the child feeling like he or she experienced the horrors of the Holocaust him- or herself, as will be demonstrated below by Grossman's protagonist. An over-identification of the child with his or her parents produces difficulties in the processes of constructing an independent identity and separating from the parents. Because of the children's internalization of the parents' experiences and over-identification with them, the children sometimes develop behavioral difficulties that express the trauma suffered by the parents (Kellermann 1999, 2001a; Rowland-Klein and Dunlop 1998).

\subsection{The Sociological or Cultural Approach}

Unlike the first approach which stresses the identification (or over-identification) of the children with their survivor parents, the sociological approach emphasizes the factor of social learning - the ways in which children of survivors construct their world of representations and imagery by learning from their parents, especially from their parents' behaviors. Children of survivors were often raised under a plethora of restrictions due to their parents' apprehensions and mistrust in the world. They grew up in households replete with fears and "taboo" subjects that were barred from discussion. Nevertheless, these approaches focus not only on the verbal messages communicated by the parents, but also on indirect learning, based on the parents' behaviors. Different studies point to the survivor parents' attitudes and behaviors around food and eating as examples of the kind of behaviors on which social learning is based, including food hoarding, obsessive eating, food-related anxieties, etc., as well as behaviors related to night terrors, among others (Kellermann 2001a). The central theme in the life of Grossman's second-generation protagonist is fear. This is shown in the analysis of the novel later on.

\subsection{Communication and Family Structures}

These approaches focus on family ties and structures of communication within the family as the central factors explaining the transmission of Holocaust trauma from parents to children. In quite a few 
cases, families of survivors functioned as "islands" wherein most of the interactions took place within the family, and perhaps occasionally with other Holocaust survivors. This theoretical explanation of the relationships within the family serves as a basis for understanding the family unit in the novel See Under: Love. The effects of this phenomenon on family functioning are described below.

\subsubsection{Parental Over-Protectiveness}

Natan points out that many members of the second generation grew up under what she calls parental "over-protectiveness", which manifests itself as excessive worrying and restricting the child's exposure to the outside world (which is perceived as threatening), wariness of strangers, and more (Natan 1981). A certain facet of this over-protectiveness is expressed in the symbiotic relationship between the children and their survivor parents (Vardi 1990). This symbiotic relationship often gives rise to the feeling that the second-generation children weree always with their parents, even in the period preceding their birth (Gampel 1982). The symbiosis, alongside this feeling that the children were "always there", often leads to over-identification of the children with their parents as victims or survivors (Kellermann 1999).

\subsubsection{Guilt and Material Compensation}

Vardi claims that one of the central aspects of the survivor personality is the feeling of guilt over the death of their loved ones "back there" (Vardi 1990). In many instances, this guilt presented an obstacle in the way of survivors developing familial attachments to the new families they started after the Holocaust. Natan, as well as Sorcher and Cohen, also argue that, in many cases, the parents, depleted by the ordeals of the past, tended to feel tired, have a short fuse, and to not always be capable of accommodating their child emotionally (Natan 1981; Sorcher and Cohen 1997). Therefore, they tended to make up for these behaviors by over-providing for the child's material needs, at the expense of emotional availability and support.

\subsubsection{High Degree of Codependence in the Child-Parent Relationship}

Another characteristic typical of second-generation survivors is a high degree of codependence with their parents. Because of the trauma of separation that was forced upon them in the past, survivor parents were not always able to "separate" from their children or to "let them go". The children, in turn, could sense their parents' dependence on them and were thereby held back from developing their own, separate, independent identities. They found it hard to "free themselves" from their original family units even in adulthood, when they became materially independent and started their own families (Vardi 1990; Natan 1981). The symbiotic relationship between parents and children, in which each side is overly preoccupied with the wellbeing of the other, often creates a situation in which the children take on the role of the parents and function as "parental children". As a result, their needs are not sufficiently met, leading to functional difficulties later on in life.

\subsubsection{Conspiracy of Silence}

Another dominant characteristic of second-generation families is the conspiracy of silence. The conspiracy of silence is also a central motif in the novel See Under: Love. In many such families, there was an "unspoken agreement" not to discuss the traumatic events of the Holocaust, most often out of the desire to protect the children. Despite this, the children tended to perceive this silence as emotional distance, which affected the quality of the relationship between parents and children (Natan 1981). Vardi claims that many survivor parents "closed their hearts" to their children, and the latter, in response, preferred to avoid speaking out or expressing emotions in public, which, in many cases, became a familial pattern (Vardi 1990). Nevertheless, some scholars dispute the "conspiracy of silence" theory, claiming that Holocaust survivors did not remain silent, but were in fact eager to tell their stories (Yablonka 2001). The change, they claim, came about after the Eichmann 
trial, since, following this much publicized event, the circle of those willing to listen to survivors greatly expanded.

The Holocaust survivor Primo Levi attested to the conspiracy of silence in his book Auschwitz Testimonies (Levi and Benedetti 2017). In an essay included in this book entitled Anniversary, Levi writes the following:

Yet the silence prevails ... That they should keep silent about this in Germany, that the Fascists should keep silent, is natural and, all things considered, not unwelcome to us ... But what shall we say about the silence of the civilized world, about the silence of culture, about our own silence in front of our children ... It is not due simply to weariness ... It is shame. We are men, we belong to the same human family to which our torturers belonged. Confronted by the enormity of their guilt ... we are not able to feel exempt from the accusation ... We are the children of the Europe where Auschwitz exists; we live in the century in which science was warped and gave birth to the racial laws and the gas chambers ... A greater crime would be impossible to imagine. They insolently constructed their realm with the tools of hatred, violence and lies. (Levi and Benedetti 2017, pp. 67-69)

The phenomenon of the years of silence and silencing was not exclusive to Israel. Shapira posits that Zionism and Israeli culture were not the sole culprits in the matter, and points out that the reemergence of the survivors' private memories took place around the same time in the entire Jewish world (Shapira 1997). Therefore, we must also look to the changes that took place in the Holocaust survivors' status in society, as well as in their age and the ages of their children, in their maturing outlook on their past, and in their ability, as years went by, to deal with this past (Shapira 1997, pp. 102-3).

\section{Transgenerational Transmission of Holocaust Trauma-Aggravating and Mitigating Factors}

The second generation (much like their parents) are by no means a homogenous group—not in their psychological attributes and not when it comes to the specific circumstances in which each of them was born and raised. It, therefore, stands to reason that symptoms listed above are likely to manifest themselves in different ways and in different amplitudes across the second generation of survivors (Kellermann 2008). Indeed, studies that looked at the transmission of Holocaust trauma effects to members of the second generation found that it is possible to attribute the variance in the expression of the abovementioned phenomena, which we can aggregate under the title "second-generation syndrome", to several factors, as described by Kellermann (2001b). The first factor is the birth year of the second-generation survivor: it was found that the closer the children were born to the end of the war, the first decade after the war in particular (until 1955), the greater the influences of the trauma were likely to be. The second factor that amplifies the potential of trauma transmission is both parents being Holocaust survivors (as opposed to cases in which only one of the parents is a survivor, while the other did not experience the horrors of the Holocaust). Another aggravating factor is being born to parents who lost children in the Holocaust: this set of circumstances, in which being a parent to a child born after the Holocaust is not the first time the survivor experienced parenthood, increases the likelihood that the parent will see the child born after the war as a "replacement" for the child or children who were lost. Yet another factor that affects the potential of transmitting trauma is the severity of the trauma experienced by the survivor parent. Traumatic experience is, of course, subjective, but it was found that parents who experienced torture, great suffering, or a difficult loss during the war-for example, the loss of close family members, had a greater chance of transmitting the trauma to the next generation.

\section{Second-Generation Holocaust Survivors}

Many survivors saw the act of starting a new family as an act of triumph over the Nazis. The new generation that was born during the first decade after the end of the war emerged into a world that 
was half-alive and half-dead, to parents full of internal conflict and confusion. These infants were often burdened with the task of serving as a kind of life preserver for the wounded parents and supplying their lives with new purpose (Vardi 1990, pp. 32-33). The parents expected their children to compensate for and replace the family members who died during the war, and developed unrealistic and unconscious expectations that their offspring would cancel out the devastation they experienced and fill their empty lives with meaning. Becoming an individual and relinquishing the conscious responsibility of constantly taking care of their survivor parents was, therefore, a rather difficult task for many of the second-generation survivors. The parents communicated to their children that they would not be able to withstand another separation and, therefore, we find many instances of survivor parents who are over-involved in their children's lives. As Hass describes it, whenever he would talk back to them or come home late without telephoning first, his parents would invariably lament: "For this I survived the Nazis? For this I survived the camps?" (Hass 1996, p. 51).

\subsection{The Second Generation as Objects}

The functioning of the typical family structure in survivor families after the war also defined the role of the children and their place in their parents' consciousness. In many cases, the children were not perceived as full-fledged individuals in their own right, but as symbols for what the parents lost "back there". This argument, too, is a dominant theme in Grossman's novel. One of the clearest indications of this is the practice of naming the child after a relative who was killed. The bestowal of a name is a symbolic act, as it were; however, in fact, many children named after the dead felt as if they were carrying the dead on their shoulders and serving as a "yarzheit candle" to their memory (Vardi 1990; Russel 1974). In addition to naming, another psychologically significant act was transforming the second-generation children from individual subjects to objects through which the survivor parents tried rebuilding their identity (Barocas 1973). Vardi claims that the children of survivors were laden with the familial and national burden of filling the emotional space left in the hearts of their parents who lost loved ones, and carrying on the family history. At the national level, the children of the second generation were a symbol of victory over the Nazis and material proof that the Jewish people would persevere (Vardi 1990).

\subsection{Post-Traumatic Characteristics}

Many members of the second generation show signs of PTSD such as fear, feelings of helplessness, and more. As already mentioned, the syndrome can sometimes manifest itself as a result of secondary trauma, which can be experienced as real trauma (direct behavior of the parent toward the child) or as internalized trauma in the child's inner world as he or she takes on parts of the parent's experiences through the process of over-identification (Felsen and Erlich 1990; Kellermann 1999; Yehuda et al. 1998). Nevertheless, researchers stress that PTSD can be caused not only through direct experience of a traumatic event, but also through the experience of witnessing trauma in others (Lanzman 2009). The various aspects of post-traumatic patterns in the survivor generation include fear of a second Holocaust, preoccupation with death, fixation on the traumatic events experienced during the Holocaust, distress caused by stimuli reminiscent or representative of the Holocaust, and more. These can also be found, as mentioned previously, among the second-generation children who did not experience the Holocaust (Kellermann 1999). In addition, members of the second generation also exhibit high incidence of anxiety, feelings of persecution, mood swings related to feelings of grief and loss, heightened sensitivity to stressful events, and severe difficulties in developing a positive self-image (Guy 1995).

\subsection{Communication Patterns}

Among the abovementioned patterns related to transgenerational transmission, we mentioned excessive familial dependence. However, we can alternatively also find "excessive independence" that has to do with the child's inability to deal with a state of dependence, as well as difficulties 
in developing intimate relationships and social ties. These are often accompanied by difficulties in dealing with interpersonal conflicts, distancing one's self from the social environment, and perceiving it as hostile (Guy 1995; Kellermann 1999). It was also found that second-generation children have a heightened tendency to develop communication problems and to experience a lack of confidence in their relationships with others (Aviad-Wilcheck and Cohenca 2011). However, the researchers qualify this finding by insisting on the difference between second-generation children whose parents went through the Holocaust alone, in which case the communication difficulties were aggravated, and those whose parents went through the Holocaust with a loved one.

\subsection{The Search for Meaning}

Members of the second generation have a heightened tendency (in comparison to their contemporaries who are not children of Holocaust survivors) to search for meaning and purpose in their lives-this as a way of dealing with anxiety and depression (Aviad-Wilcheck and Cohenca 2011). It is of great importance to the survival of man to discover the meaning of existence, however vague. Frankl spoke of the survival value of the ability to invest life with meaning (Frankl 2006). He himself learned of its value during the three years he spent in Auschwitz and other extermination camps, where his parents, his brother, and his wife perished. Throughout this period, Frankl developed his existentialist views on therapy and on mankind. His bitter struggle for physical existence, and his observations of people who succeeded in overcoming the inferno and surviving by virtue of the purpose they set for themselves, as opposed to those who lost the taste of life and perished, led him to a deep understanding of human existence, which is not only self-fulfillment but transcendence of the self and finding the meaning of life: "I understood how a man who has nothing left in this world still may know bliss, be it only for a brief moment, in the contemplation of his beloved ... Soon my soul found its way back from the prisoner's existence to another world, and I resumed talk with my loved one" (Frankl 2006, p. 49).

\subsection{Other Effects on Overall Function}

Naturally, emotional difficulties and deficient communication patterns experienced by the second generation also affect their daily functioning. Learning is one of the areas most affected by the abovementioned symptoms, including overall poor performance at school, learning disabilities, and a lack of motivation (Berger and Ivgi 2009). Difficulties of this kind were also experienced by Grossman's protagonist, as I shall demonstrate below. On the other hand, researches also point to a contrary trend of an excessive need for over-achievement in various fields, which seems to want to compensate for the losses suffered by the parents-not only emotional losses, but also the cessation of their "normal lives"-including education, work, etc. (Kellermann 1999). Other studies looked at the physical and medical symptoms exhibited by the second generation and find that they have a higher incidence of high blood pressure, diabetes, and sleep disorders relative to their age group (Shrira 2017).

\section{Representations of the Holocaust in Literature}

Representing the Holocaust in any art form poses a significant challenge since, in the symbolic language of the arts, this representation includes an inherent element of failure stemming from the inability of art to contain the dense and traumatic experience of an event as cataclysmic as the Holocaust (Ben-Dat 2015, p. 30). Symbolic language lacks the capacity to represent trauma with any kind of reliability or authenticity and, therefore, cannot be charged with preserving the memory of a traumatic historic event (Felman and Laub 1992, pp. 8-9). On the other hand, testimony takes up a position of unparalleled importance. Bearing witness to a crisis or a trauma can teach us about the depth of the catastrophe; it is the act of communicating to others and in the name of others. In a speech made in Sweden on the occasion of receiving the Nobel Prize, Albert Camus argued that the writer is not exempt from difficult duties. He cannot serve those who make history, but he must serve those who suffer it (Camus 1957). "If someone else could have written my stories", wrote Holocaust survivor 
Elie Wiesel, "I would not have written them. I have written them in order to testify. My role is the role of the witness ... Not to tell, or to tell another story, is .. to commit perjury" (as cited in Felman 1991, p. 39). Testimony is composed of fragments of memory and does not offer a complete statement regarding the events. There are even those who claim that testimony is the predominant literary (or discursive) mode of our times (Felman and Laub 1992, p. 5).

The term "Holocaust literature" is wide-reaching and encompasses the totality of literary texts that deal with the Holocaust period, as well as literature which focuses on the lives of survivors after the war. It includes texts from all kinds of genres across the literary spectrum including fiction, poetry, history, personal diaries and memoirs, short stories, nonfiction, and more (Yaoz 1980). In this article, I focus on a fiction that deals with the Holocaust period and the experiences of survivors from the point of view of the second generation.

Milner claims that literary responses to the Holocaust in Israel began appearing in the cultural arena directly with the arrival of the first news stories relating to the destruction of the Jews in Europe (Milner 2012). In the first years after the Holocaust, Holocaust literature served as the background and justification for the establishment of the Israeli state and advancement of the Israeli nation. In the second stage, following the Eichman trial and up until the end of the 1970s, the emphasis was placed on the tragedy of the Holocaust, the personal and collective trauma, and the victims (Milner 2012). The third stage, beginning with the 1980s and up until today, is characterized by a shift in focus toward the survivors and their ways of coping with the Holocaust experience and its memory. In addition, the literature also deals with members of the second generation-whether as written by authors who write and process their emotional experiences as children of survivors within the framework of autobiography, or as written by authors who are not directly related to Holocaust survivors, but who represent the second generation in fiction.

The characters representing the second generation in "Holocaust literature" are mostly described as educated people with extensive historical knowledge about, among other things, the destruction of European Jews during the Second World War. The literature addresses the socio-cultural reality in which they grew up, in particular the silence that prevailed in the households. The common denominator underpinning all of the psychological literature pertaining to the second generation is the understanding that there exist significant similarities in the behavioral, emotional, and cognitive patterns presented by this generation, and that the functional difficulties they must deal with stem from the dynamic between the survivors and their children (Berger and Ivgi 2009; Milner 2012).

\section{See Under: Love by David Grossman}

The present article focuses on the novel See Under: Love as a case study by the award-winning Israeli author David Grossman, which examines the Holocaust from the perspective of Momik, a child of Holocaust survivors (Grossman 2002). The book was first published in 1986 and was one of the first works of fiction to deal with the effects the Holocaust had on the second generation. It is considered a groundbreaking work in the field of second-generation literature and is unique in that it is the first novel written about the Holocaust by an author who is not a survivor, nor the child of survivors (Laor 1993). The novel is composed of four distinct parts that differ from one another in writing style and in the characters they focus on: "Momik", "Bruno", "Wasserman", and "The Complete Encyclopedia of Kazik's Life". The character of Momik, however, appears in each part of the story, either as a central character in the plot or as the author/narrator. Grossman's novel dealing with the family of survivors belongs to the genre of psychological novels. This type of work does not intend to describe the facts accurately, but rather to convey the intense experience of the second generation in Israeli society.

\section{Momik's Childhood}

The nine-year-old Momik (full name: Shlomo), Grossman's protagonist, is a primary-school student in the Beit Mazmil neighborhood of Jerusalem in the 1950s. He is the son of two Holocaust 
survivors, Tuvia and Gisella Neuman, who take care not to expose him to the horrors of the Holocaust out of a desire to protect him. Momik's father was a forced laborer (a Sonderkommando) in Auschwitz during the war. We do not know much about Momik's mother's experiences of the Holocaust, but we do know that she too is a survivor. Kellermann's study relating to the aggravating factors of transgenerational transmission indicates four main elements which are all present in Momik's case, in the Neuman family: (1) both parents are survivors; (2) Momik is an only child; (3) the trauma experienced by his father as a Sonderkommando is severe in the extreme; (4) the story hints at the fact that Momik had a brother who died during the war (Kellermann 2008).

His parents experienced a real threat to their physical and mental wellbeing - the definition of trauma in the research literature (Perry 2007). Likewise, the research hypothesis that members of the second generation were significantly affected by the traumas their parents were subjected to during the Holocaust (Baranowsky et al. 1998; Berger and Ivgi 2009) is manifest in multiple aspects of Grossman's protagonist. Momik's parents categorically refuse to share their memories of the Holocaust and avoid any discussion on the subject. The household abounds in signs of anxiety and obsession-the father wakes up screaming at night, the house is always secured with an exorbitant number of locks, friends are not allowed to come over, they obsessively count the cutlery and kitchenware, and the description given of the parents' eating habits is in the realm of the grotesque. The trauma suffered by Momik's father is acute to the point that he cannot touch his son because he feels that his hands are "tainted with death". All of these are expressions of symptoms typical of post-traumatic stress (Steier 2009, p. 148). Momik is aware of his role as the family's "yahrzeit candle" and, as such, he is wholly engrossed in the subject of the Holocaust (Vardi 1990, p. 38).

Momik goes to the family home of Anshel Wasserman, his deceased grandmother's brother, whom Momik calls "grandfather" and who used to be a children's author writing for a Hebrew newspaper in Warsaw during the war. Momik takes care of "grandfather" and, with his help, tries to put together the fragments of the story and deepen his understanding of "the land of Over There" which incites his curiosity. In the absence of reliable information from his parents, he creates his own "Holocaust" world in the cellar of the house, becoming more and more socially isolated as he sinks deeper and deeper into a Holocaust of his own making. The literary characterization of the boy lets us know that, in many ways, Momik is not a "typical child"; he is described by his family members as an "alter kopf" — the head of a smart old man (8).

Even his name is emblematic of the heavy burden placed on his shoulders. Throughout most of the book he is referred to as Momik (or Shlomik as an adult) or by his full name-Shlomo Efraim Neuman. His grandmother used to call him by the names of all the family members who had died in the war: "Mordechai Leibeleh, and Shepseleh and Mendel and Anshel and Shulam and Chumak, and Shlomo Haim, and that's how Momik got to know who they all were" (26). Momik carries a heavy load of dead relatives whose names are attached to him. The research literature likens this phenomenon of naming second-generation children to an act that erases their existence as individual subjects, so they can serve instead as "yahrzeit candles" (Vardi 1990), as objects meant to embody in name and in essence those who were lost (Vardi 1990; Russel 1974).

Momik's parents live in constant anxiety and Momik almost never leaves the house (other than to go to school). His daily life in the house is also subjected to his parents' unrelenting concern: "There's a drumstick in the refrigerator for you and one for him ... and be careful with the small bones, you shouldn't swallow any, God forbid ... And be careful with the gas too, Shleimeleh, and blow the match out right away, so there won't be a fire, God forbid ... And don't drink soda water out of the refrigerator. Yesterday I noticed at least one glass less in the bottle. You drank it, and it's winter now. And as soon as you're inside lock the door twice. The top lock and the bottom lock. Just once is no good" (22-23).

Momik, who can sense that something is amiss, puts all his efforts into finding out about the place he calls "the land of Over There", which, in his mind, is his only chance of saving his parents: "like spying on his parents, and all the spy work to put together the vanished land of Over There like a 
jigsaw puzzle, there's still a lot of work left on this, and he's the only one in the whole wide world who can do it, because who else can save Mama and Papa from their fears and silences ... which was even worse after Grandfather Anshel turned up and made them remember all the things they were trying so hard to forget and not tell anyone" (18). His parents, as stated previously, are unwilling to share any of their memories with him and, therefore, he tries to piece together a picture of Over There from the shards of information that he happens to overhear, while giving that information his own interpretation based on his own world. Thus, for example, when he hears that his father was a Sonderkommando in Auschwitz during the war, he interprets this information based on the meaning of the familiar word "commando"-meaning fighter-and, therefore, associates positive elements of bravery in battle to this period of his father's life. Likewise, he tries to use his limited knowledge of arithmetic to try and decipher the meaning of the numbers tattooed on the arms of the Holocaust survivors around him, etc.

\section{The "Holocaust" in the Cellar}

As part of his efforts to try and understand what went on in the land of Over There, Momik talks to Bella, his neighbor, who tells him that the "Nazi beast can come out of any animal" (13). Momik then starts to collect various animals—a baby crocodile, a porcupine, a cat, a pigeon, and others-with the aim of raising the "Nazi beast" out of them so he can then fight it and defeat it in order to save his parents: "Momik reversed his tactics, figuring that what he needed in order to fight the Beast was the very thing that most scared it, the thing he'd been avoiding all along, which was to get to know more about the Beast and its crimes, because otherwise he'd just be wasting energy" (65). He endeavors to gain knowledge about the Holocaust by reading books in secret from his parents, while trying to recreate the Holocaust in the cellar. He figures that he must "show the Beast the food it liked best-a Jew" (68).

In my opinion, it is possible to see Momik undergo a transformation from victim (he is a victim of bullying, but also in a certain sense, of his parents) to aggressor: "To tell the truth, there are days when Momik sits in the cellar half awake and half asleep and he envies the Beast. Yes, he envies it for being so strong that it never suffers from pity, and that it can sleep soundly at night even after all those things it did, and that it even seems to enjoy being cruel ... and to tell the truth, Momik has also been kind of enjoying it lately when he does something really bad ... he could almost fling himself against the cages and shatter them and smash every head on the Beast without mercy" (69-70).

Also, Vardi addresses this issue of "victim and aggressor" by viewing them as two faces of the same archetype, which a single person may embody; the aggressor is the active aspect of the archetype while the victim is the passive aspect. The character of Momik contains both the victim and the aggressor at the same time- both as a child and as an adult. The child Momik, in trying to save his parents, assumes the opposite role from the role of the victim played by his family, the role he too plays initially in relation to his bully classmates until he himself becomes the aggressor-when he begins to lock up animals, and later people, in the cellar of his house. He puts Grandfather Anshel in the cellar and does not let him go up to the house: "Momik sat looking at Grandfather Anshel ... He was fed up with this stupid grandfather who did nothing but drawl out his crummy story in a whiny voice. Sometimes Momik felt like going over to him and snapping his mouth shut. Once when Grandfather made a sign that he had to pee, Momik didn't get up to take him out but sat staring into his eyes instead, and he saw how confused Grandfather was, howling like some crazy cat ... and then he wet his pants and they smelled revolting, but Momik wasn't the least bit sorry for him anymore ... Momik just got up and walked out, leaving Grandfather all alone in the dark" (79-80).

\section{Assimilation of the Holocaust as Part of Momik's Identity}

It seems as if his creation of the "Holocaust cellar" and the books he reads, as well as the exposure to information and images unsuitable for a nine-year-old's level of maturity and understanding, make the Holocaust trauma an inherent part of Momik's identity. The more Momik learns about it, the more space it takes up in his mind. Momik becomes part of the land of Over There: 
"The cellar was filled with the sounds of danger and fear, and it seemed incredible that only half a minute from here there was a city and people and books ... he went over to his Jews, and they looked at him with sad, worried faces ... and he was still laughing at them in his heart for their willingness to forgive him so soon after what he'd done to them ... but when he opened his eyes and saw them all around him, tall and ancient, gazing at him with pity, he knew with all his nine-and-a-half-year-old alter kopf intelligence that it was too late now" (85-86).

Momik stops going to school and spends all his time either in the cellar or reading books about the Holocaust, which becomes an important part of his world. Another sign of Momik's transformation into someone from Over There is his attitude toward the green bench-the neighborhood bench that serves as a gathering place for Grandfather Anshel and the "crazy"2 people-such as Hannah Zeitrin, who runs naked in the street at night yelling for God to take her, Ginzburg, who keeps asking who he is, Zeidman, who copies the movements of the people next to him, Mr. Munin, who sleeps in the synagogue at night, and Mr. Aaron Marcus, who always makes faces. At first, Momik is afraid to come near the bench, but gradually he comes closer, stands at a distance, and listens to the conversations while jotting down their stories. Later, Momik joins the bench occupants and gives them the title of "secret warriors". He even claims not to care if people think they are crazy because, as far as he is concerned, they are his friends.

\section{Academic Deterioration and Expulsion}

Momik's assimilation into the world of Over There is quick and dramatic. Only five months after Grandfather Anshel comes to stay with them, Momik's school performance deteriorates to the point where he is expelled. He goes from being an honor's student-a fact that is listed as one of his strongest qualities- to flunking out, and even his transfer to another school is of little interest to him: "His teacher Netta came over to talk to Mama and Papa, and they agreed about certain things. Momik didn't care. He didn't even ask... At the end of the school year Momik's report card said Promoted, but not at our school, and Mama told him that the following year he would attend a special school near Natanya, and he wouldn't be living at home, but this was for his own good" (86). Momik's relatively high functionality and eagerness to please is replaced by an apathy that bears close resemblance to the descriptions of Grandfather Anshel, who seems to not always be aware of or to simply not care about what goes on around him.

This aspect of Momik's personality is also present in the research literature, since second-generation children, as far as academic achievement is concerned, tend to oscillate between an excessive drive to overachieve as a way to make up for the parents' loss of their "normal lives" on the one hand, and a diminished performance at school, learning disabilities, and a lack of motivation on the other (Berger and Ivgi 2009). It is interesting to note that, as a child, Momik exhibits both these patterns at different times: in the period preceding his radical exposure to the Holocaust trauma, Momik is an honor's student, who strives to please his parents and best his classmates in terms of academic achievement, whereas, after the process of exposure, he is frequently absent from school and shows a lack of motivation that eventually gets him transferred to a "special school".

\section{Fear of Emotion}

As an adult, Momik himself becomes an author who tries to write about the Holocaust. His marriage with Ruthy is on the rocks, and he maintains complicated relationships with her and with Ayala, his mistress. One of the main themes that emerge around the character of adult Momik is

2 Therapists report that in conversations with members of the second generation, they tended to portray their surviving parents as disturbed (Hass 1996, p. 86). In the post-war period, Israeli society also viewed the post-trauma symptoms of Holocaust survivors as madness and mental illness (as described in Almagor 1985 novel The Summer of Aviya, for example), whereas studies point out that the boundary between mentally ill and healthy patients is fluid, since "normal" patients may become "ill" given severe enough trauma (Ofir 2013, p. 147). 
the fear of emotion. It seems that Momik's growing up is a gradual process of distancing and active emotional avoidance. Also, according to Vardi's research, "Yarzheit candles", are caught in the internal struggle between the dead part of their psyche - the part that is empty of emotion, and the living, feeling part (Vardi 1990).

The third part of the novel, "Wasserman", tells the story of Anshel Wasserman, renowned Jewish childrens' author and the brother of Momik's grandmother, whom Momik calls "grandfather". This chapter describes the relationship between Wasserman, who is unable to die, and the commander of the camp, Herr Neigel. Wasserman tells Herr Neigel a story in installments and, in return, the camp commander agrees to try his best to kill Wasserman. In this chapter, we come to know that Momik is now residing in a rented apartment in Tel Aviv, without his wife or mistress, for the purpose of trying to write about the Holocaust. It is there that he first comes up with the idea of the "white room" in the Holocaust Memorial Library in Jerusalem-Yad Vashem-where he would be able to write while accessing the violent parts of himself. The fourth part of the novel, "The Complete Encyclopedia of Kazik's Life", is written by Momik and structured in the scientific style of an encyclopedia-alphabetical and ostensibly random. In my opinion, Momik tries to make some sense of the Holocaust experience which he cannot contain or understand. This part attempts to tell the story of baby Kazik, who is destined to live for $24 \mathrm{~h}$ only and grows up remarkably fast. Throughout the "Encyclopedia", it is possible to identify numerous expressions of Momik's emotional distance and detachment as an adult. Thus, for example, the entry for "love" in the encyclopedia redirects the reader to the entry for "sex" - an unambiguous sign that he denies the emotional aspect of the love relationship. Similarly, under "feelings", Momik writes that feelings are "a subjective inner experience ... and rule out the possibility of drawing objective general conclusions" (439). Nevertheless, in the entry for "documentation", Ayala asks the adult Momik (Shlomik) to feel again: "If you want to save yourself ... write me a new story ... Yes, yes, I know your limitations: I don't expect a happy ending from you. But promise me that at least you'll write with MERCY [q.v.], with LOVE [q.v.]! Not See under: Love, Shlomik! Go love! Love!" (450). Ayelet's supplication attests to Momik's emotional deafness and the same pattern of emotional detachment can be seen in his relationships with his wife, Ruthy, and with his son, Yariv.

\section{The Search for Identity}

The process of investigation that Momik embarks on as a child continues into his adult life as well. He attempts, through this journey, to bring his grandfather back to life-whether in reality or as a metaphor. However, it seems that this search and the tracing of his grandfather's history prevent him from moving on with his own life: "And I spoke about fear. And about Grandfather, whom I can't seem to bring back to life, not even in the story. And about being unable to understand my life until I learn about my unlived life Over There" (109). Momik is unable to live his "real" life in Israel because he is living a parallel life "Over There".

Even as a grown man, Momik is unable to separate the lives of the characters he writes about from his own life. We can see this reflected in the points of resemblance between Momik and Grandfather Anshel: they are both average, both struggle with repression and silence, and Momik decides to be a writer in Grandfather Anshel's footsteps-a decision he makes when he is still a child and which he deems "an important decision". In the last part of the book, about the life of baby Kazik, under "CHATUNA" - "WEDDING", Momik, the author, refers to his own wedding with Ruthy-an excerpt that seems disconnected from the narrative flow, yet emblematizes the intermingling of Momik's world with the world of his characters from Over There (333).

As discussed previously, one of the traits attributed to the second generation is the heightened tendency to search for meaning as a way of dealing with depression (Aviad-Wilcheck and Cohenca 2011). Momik is looking for meaning in his present life by trying to untangle and understand the past. This attempt to create meaning is also reflected in his endeavor to write an "Encyclopedia" that would contain the entirety of one person's life-that of baby Kazik. However, as the story gradually reveals, 
this attempt too is doomed to failure. Momik proves incapable of writing the encyclopedia and, at the same time, incapable of filling his life with satisfactory meaning.

\section{Repercussions on Momik's Adult Life}

Momik's interest in death and the Holocaust is obsessive, and the Holocaust experience utterly dominates his inner world and his imagination. As I mentioned, the communication patterns characteristic of the second generation include, among others, an excessive independence that stems from an inability to tolerate dependence on another, which leads to difficulties in developing intimate and social relationships (Aviad-Wilcheck and Cohenca 2011; Guy 1995; Kellermann 1999). Throughout the novel, it appears that the most meaningful relationships Momik has as an adult are with people who are no longer alive (such as Grandfather Anshel) or with fictional characters that he himself invented. His real-life relationships with his family, his son, his wife, and his mistress are described as cold and distant, marred by emotional detachment.

Momik pays a hefty price for a life led in an environment steeped in severe Holocaust trauma. The influences and repercussions of his upbringing can be seen in his professional life, his romantic relationships, and his relationship with his son. For instance, this is how Momik describes his "broken" marriage with Ruthy: "Sometimes I want to make it up to her. I could cry when I think about the day she'll be lying there in critical condition and I walk in to donate a kidney that saves her life. It's hard to imagine a nobler sacrifice. Sometimes I actually look forward to it. Then she'll see: her whole life with me will take on a different meaning. She will understand the truth and her heart will bleed. Oh, my darling, the hell you must have lived through" (104). This relationship ends up breaking down entirely. The couple separates, and Ruthy bids Momik farewell saying: "I hope you find what you're looking for so we can start living again" (107).

Momik has one son, named Yariv. This relationship is portrayed as being devoid of emotion, similarly to the relationship Momik had with his father, who never touched him. For example, this is how Momik describes spending time with Yariv in the park: "He's taller and sturdier than most children his age, and that's good, but he's afraid of them. He's afraid of everything. I have to climb the slide because he refuses to move without me. I climb down again and leave him there crying that he's afraid he might fall. Some kindly soul walks over to inform me that he's afraid. I smile, coldly beatific, and tell her that out in the forests children his age were used as sentinels and made to sit guard for hours high in the treetops" (149). As far as Momik is concerned, his role as a parent is to prepare his son for life. Yet, it seems that the life Momik is preparing Yariv for is life in the land of Over There: "Always stand in the middle row. Never reveal more than you have to. Remember things are seldom what they seem ... It's a good thing he can sleep through all the noise ... He may have to sleep with tanks passing in the streets someday. Or on his feet, trudging through the snow. Or in a crowded cell block maybe, with ten more like him to a bunk" (148-149).

In a conversation he has with Ruthy about Yariv's upbringing, Momik stresses the fact that his goal is to "prepare him for life", and when Ruthy points out that his behavior might take a great toll on his relationship with Yariv and affect his son's love for him, Momik retorts: "Love, I sneered maliciously, I prefer a living son to a loving son" (148). Momik is aware of the fact that he is treating Yariv in much the same manner as his parents treated him, but he senses that he cannot do otherwise: "But when his mouth sticks to my neck and trembles with a mournful sob, I feel the heavy pendulum of childish shame swing from his heart to mine with such force it almost knocks me off the ladder. Forgive me, my child, I say inwardly, forgive everything, be wiser and more patient than I am, because I don't have the strength, they didn't teach me how to love" (149).

It is interesting to look at the ending of the novel. For the last entry in "The Complete Encyclopedia of Kazik's Life", the author chose the word "TEFILLA"— "PRAYER". The final sentence of the book is a kind of prayer, ostensibly addressed to Kazik; however, in my opinion, it is really going out to all of humanity: "All of us prayed for one thing: that he might end his life 
knowing nothing of war. Do you understand, Herr Neigel? We asked so little: for a man to live in this world from birth to death and know nothing of war" (452).

\section{Epilogue}

Writing about the Holocaust, according to Grossman, is an impossible task. As his protagonist, Momik, puts it: "For the past forty years people had been writing about the Holocaust and would continue to do so, only they were doomed to failure, because while other tragedies can be translated into the language of reality as we know it, the Holocaust cannot, despite that compulsion to try again and again, to experience, to sting the writer's living flesh with it" (124); "all the books, all the pictures and words and films and facts and numbers about the Holocaust at Yad Vashem to that which must remain forever unresolved, forever beyond our comprehension" (121). On the other hand, as Grossman's protagonist testifies, the very act of trying to write about the Holocaust has a liberating and therapeutic value. As an adult, Momik tries writing about the Holocaust wholeheartedly in order to heal himself from his obsessive preoccupation, a fact that both Ruthy and Ayala realize: "If you really want to pull yourself out of this, start making an effort ... We think you should rent a room somewhere ... And you can stay there quietly on your own and write. No excuses. You can't keep torturing everyone around you like this. World War II only lasted six years, yours has been going on for thirty-five. Enough already" (157). The paradox of writing about the Holocaust is embodied in the protagonist's inability to write and understand the Holocaust combined with the obsessive need to be busy with it all the time. Bibliotherapy, treatment with the aid of books, whether by writing or by reading, can help release tension, present problems in a new light, develop awareness, open emotional blockages, break through taboos, create identification, and lead to finding new ways of dealing and self-improvement. Literature amplifies our sense of freedom and makes us question personality types that were forced upon us (Cohen 2010, p. 15). Momik's writing is his way to seek meaning in his life. By revealing and affirming our inner experience, we can achieve a certain internal certainty (May 1994).

In his novel, Grossman describes well the transgenerational transmission to the second generation, but he also points to the possibility of transmitting the Holocaust trauma to the third generation, in the character of Yariv, Momik's son. Grossman was ahead of his time in this respect, for most of the studies that examined this issue and found that members of the third generation also show symptoms of unprocessed post-traumatic stress were written after the book See Under: Love was published (Scharf and Mayseless 2011). Scholars found that many survivors who rarely spoke of their experiences in the Holocaust to their children were more likely to open up to their grandchildren, members of the third generation. As we saw, there is somewhat of a consensus about the psychological/mental repercussions of the Holocaust on the second generation of survivors; however, things are much more ambiguous as far as the third generation is concerned. Hass maintains that members of the second generation tended to promise themselves that, when they grew up, they would not repeat the harmful or hurtful behavioral patterns of their parents. They aspired to give their children more freedom and avoid the kind of stifling relationship that could suppress their personal expression and initiative. Many of them even hoped to spare their children the fear of the outside world instilled in them by their survivor parents. Some of them vowed to show more empathy and sensitivity toward their children. However, Hass also admits that some of the children of survivors did pass their anxieties onto the third generation and are aware of the fact that their heightened sensitivity has an effect on their children (Hass 1996, pp. 158-63).

In my opinion, the important universal, humanistic message that Grossman wishes to send through Momik is that every single one of us contains both the victim and the aggressor, and that, under certain conditions and in certain circumstances, the "Nazi beast" or its counterparts may awaken within each of us (Azuz 2015, p. 211). There is no understanding evil and there is no point in trying. Momik cannot get to the bottom of the land of Over There because the task he has set for himself is impossible. Nevertheless, Grossman asks us to try and understand the potential for evil in man, rather than evil itself. Momik's obsessive preoccupation with the suffering and evil that 
was perpetuated Over There turns him into an aggressor in his own right. The weak, victimized son of survivors who delves into evil and hatred in a hopeless attempt to understand them, becomes indifferent to the world around him, and that, in a sense, is the greatest danger of all.

My main conclusion from Grossman's novel is that the preoccupation with evil has the potential to unleash evil. We have a natural tendency to judge evil and to try to arrive at some scientific explanation of how something so horrible can happen at the hand of human beings (Azuz 2015, p. 211). Since there can be no logical explanation for evil, we tend to classify it as an extra-human phenomenon, something monstrous that cannot arise among "normal" human beings, and by doing so, we abdicate our responsibility for the events. However, if we wish to prevent manmade evil, we must understand humanity's potential for evil. In his essay about the rise of Nazism and the consolidation of anti-Semitism in Germany in the 1870s, Azuz writes that, for most humans, circumstances tend to override the values they "normally" adhere to, and the more extreme the circumstances, the further people will go to adapt themselves to them (Azuz 2015, p. 428).

The Holocaust was an important philosophical junction in human history, and the difficult memory of it was transmitted through different narratives, at different points in time. In Israel, the dominant proclivity in the cultural discourse was to demonize the Nazis, and Hitler above all. However, a demon, according to Bauer, resides outside the boundaries of what we define as human and, thus, demonization is a way for us to abdicate responsibility (Bauer 1978). Grossman in his novel creates a demon in the shape of the "Nazi beast" that Momik tries to confront, unsuccessfully. It is critical for our civilization to make the Holocaust a topic of discussion relevant to the everyday existence of every single human being, by presenting it as a moral discussion. The understanding that the most terrible acts humans ever committed (and are still committing) have the potential to be perpetrated by any one among us is paramount, from the humanistic perspective; only a conscious and deliberate effort to achieve it can stop similar catastrophes from happening again in the future.

Funding: This research received no external funding.

Conflicts of Interest: The author declare no conflict of interest.

\section{References}

Almagor, Gila. 1985. The Summer of Aviya. Tel Aviv: Am Oved. (In Hebrew)

Amir, Dana. 2018. Testifying about Testifiers: Four Modes of Traumatic Testimony. Jerusalem: Magnes Press.

Arev, Dan, and David Gurevitch. 2012. The Encyclopedia of Ideas. Tel Aviv: Babel Press. (In Hebrew)

Aviad-Wilcheck, Yael, and Diana Cohenca. 2011. Learning about Meaningful Life as a Way of Coping with Situations of Stress and Anxiety-The Instance of Second Generation Holocaust Survivors. In The Holocaust Ethos in the 21st Century: Dilemmas and Challenges. Edited by Nitza Davidovitch and Dan Soen. Ariel: Ariel University Center of Samaria, pp. 51-70.

Azuz, Itzhak. 2015. Understanding the Holocaust, Understanding Man's Potential for Nazism-Is the Holocaust a "Necessary" Product of European Culture? Tel Aviv: Resling Books. (In Hebrew)

Baranowsky, Anna B., Marta Young, Sue Johnson-Douglas, Lyn Williams-Keeler, and Michael McCarrey. 1998. PTSD Transmission: Review of Secondary Traumatization in Holocaust Survivor Families. Canadian Psychology 39: 247-56. [CrossRef]

Barocas, Harvey A. 1973. Manifestations of Concentration Camp Effects on the Second Generation. The American Journal of Psychiatry 130: 820-21. [CrossRef] [PubMed]

Bauer, Yehuda. 1978. Against Mystification: The Holocaust as a Historical Phenomenon. In The Holocaust in Historical Perspective. Canberra: A.N.U. Press, pp. 30-49.

Ben-Dat, Aya. 2015. From Humor to Trauma, from Ethics to Aesthetics: On Roberto Benini's Life is Beautiful. Tel Aviv: Resling Books. (In Hebrew)

Berger, Tamar, and Shira Ivgi. 2009. The Second and Third Generations. Haifa: Hedva Eivschitz Institute for Holocaust Studies. (In Hebrew) 
Camus, Albert. 1957. Camus-Nobel Banquet Speech. NobelPrize.org. Nobel Media AB 2018. Available online: https:/ / www.nobelprize.org/prizes/literature/1957/camus/25232-albert-camusbanquet-speech-1957/ (accessed on 28 August 2018).

Cohen, Adir. 2010. Being the Author of Your Own Life: Personal and Literary Narrative Discourse. Even Yehuda: Amatzia Press. (In Hebrew)

Dingut, Nili. 1986. The Poetics of Fiction. Tel Aviv: Open University Press. (In Hebrew)

Felman, Shoshana. 1991. In an Era of Testimony: Claude Lanzmann's Shoah. Yale French Studies 79: 39-81. [CrossRef]

Felman, Shoshana, and Dori Laub. 1992. Testimony: Crises of Witnessing in Literature, Psychoanalysis and History. New York and London: Routledge.

Felsen, Irit, and Shmuel H. Erlich. 1990. Identification Patterns of Offspring of Holocaust Survivors with Their Parents. American Journal of Orthopsychiatry 60: 506-20. [CrossRef] [PubMed]

Felsen, Irit. 1998. Transgenerational Transmission of Effects of the Holocaust: The North American Research Perspective. In International Handbook of Multigenerational Legacies of Trauma. Edited by Yael Danieli. New York and London: Plenum Press, pp. 43-68.

Foiss, Yael. 2006. Text, Reader and Teacher. In Teaching Literature. Edited by Sami Michael. Tel Aviv: Mofet. (In Hebrew)

Frankl, Viktor Emil. 2006. Man's Search for Meaning. Boston: Beacon Press.

Gampel, Yolanda. 1982. A Daughter in Silence. In Generations of the Holocaust. Edited by Martin S. Bergmann and Milton E. Jucovy. New York: Columbia University Press, pp. 120-36.

Grossman, David. 2002. See Under: Love. Translated by Betsy Rosenberg. New York: Picador-Farrar, Straus and Giroux.

Guy, Helen. 1995. Joie de Vivre, Intimacy and Sexuality in Second Generation Holocaust Survivors. M.A. dissertation, Tel Aviv University, Tel Aviv, Israel. (In Hebrew)

Hass, Aaron. 1996. In the Shadow of the Holocaust: The Second Generation, 1st ed. Cambridge and New York: Cambridge University Press.

Herman, Judith Lewis. 2015. Trauma and Recovery. New York: Basic Books.

Kellermann, Natan. 1999. Bibliography: Children of Holocaust Survivors. Jerusalem: AMCHA, the National Israeli Centre for Psychosocial Support of Holocaust Survivors and the Second Generation.

Kellermann, Natan. 2001a. Psychopathology in Children of Holocaust Survivors: A Review of the Research Literature. Israel Journal of Psychiatry and Related Sciences 38: 36-46.

Kellermann, Natan. 2001b. Transmission of Holocaust Trauma-An Integrative View. Psychiatry Interpersonal E Biological Processes 64: 256-67.

Kellermann, Natan. 2008. Transmitted Holocaust Trauma: Curse or Legacy? The Aggravating and Mitigating Factors of Holocaust Transmission. The Israel Journal of Psychiatry and Related Science 45: 263-71.

Kestenberg, Judith. 1972. Psychoanalytic Contributions to the Problem of Survivors from Nazi Persecution. Israel Annals of Psychiatry and Related Disciplines 10: 311-25. [PubMed]

Lanzman, Moshe. 2009. Three Cases of Collective Post-Traum. Psychoactualua 10: 32-36. (In Hebrew)

Laor, Dan. 1993. The Influence of Survivor Literature, '1948' Authors and Second Generation Authors on the Changing Image of Kasztner and Depictions of the Holocaust in Israel. Kathedra Letoldot Eretz Israel Veyeshuva 69: 133-64. (In Hebrew)

Levi, Primo, and Leonardo De Benedetti. 2017. Auschwitz Testimonies, 1945-1986. Edited by Fabio Levi and Domenico Scarpa. Translated by Judith Woolf. Cambridge: Polity Press.

May, Rollo. 1994. The Discovery of Being: Writings in Existential Psychology. New York: Norton.

Milner, Iris. 2012. Momik, a Child on Fire: The Ethics of Trauma in Momik by David Grossman. Ot Ktav Et Lesefrut Uleteoria 2: 191-210. (In Hebrew)

Natan, Tikva. 1981. Second Generation Holocaust Survivors in Psycho-social Research. In Dapim Leheker Tkufat Hashoa 2: 13-26. (In Hebrew)

Ofir, Orna. 2013. On the Brink of Madness-Psychoanalysis, Psychiatry and Psychosis in America. Tel Aviv: Resling Books. (In Hebrew)

Perry, Bruce D. 2007. Stress, Trauma and Post-traumatic Stress Disorders in Children. The Child Trauma Academy 17: 42-57. 
Rakoff, Vivian, John J. Sigal, and Nathan B. Epstein. 1966. Children and Families of Concentration Camp Survivors. Canada's Mental Health 14: 24-26.

Rowland-Klein, Dani, and Rosemary Dunlop. 1998. The Transmission of Trauma across Generations: Identification with Parental Trauma in Children of Holocaust Survivors. Australian and New Zealand Journal of Psychiatry 32: 358-69. [CrossRef] [PubMed]

Russel, Alex. 1974. Late Psychological Consequences in Concentration Camp Survivor Families. American Journal of Orthopsychiatry 44: 611-19. [CrossRef]

Scharf, Miri, and Ofra Mayseless. 2011. Disorganizing Experiences in Second- and Third-Generation Holocaust Survivors. Qualitative Health Research 21: 1539-53. [CrossRef] [PubMed]

Shakedi, Asher. 2003. Words Attempting to Touch: Qualitative Research-Theory and Practice. Tel Aviv: Ramot. (In Hebrew)

Shapira, Anita. 1992. The Dove and the Sword. Tel Aviv: Am Oved. (In Hebrew)

Shapira, Anita. 1997. New Jews, Old Jews. Tel Aviv: Am Oved. (In Hebrew)

Shrira, Amit. 2017. Does the Holocaust Trauma Affect the Aging of the Second Generation? Paper presented at the Annual Seminar on Innovations and Challenges in the Fields of Gerontology \& Geriatrics, Beer-Sheva, Israel, April 19.

Sigal, John J., and Morton Weinfeld. 1989. Trauma and Rebirth: Intergenerational Effects of the Holocaust. New York: Praeger.

Sorcher, Nechama, and Lisa J. Cohen. 1997. Trauma in Children of Holocaust Survivors: Transgenerational Effects. American Journal of Orthopsychiatry 67: 493-500. [CrossRef]

Steier, Shmuel Tommy. 2009. Why Are They Silent Again? On the Psychological Condition of Holocaust Survivor and Their Treatment at the Hands of Caretakers and Society. Harefua 148: 219-23. (In Hebrew)

Vardi, Dina. 1990. Bearers of the Seal: A Dialog with Second Generation Holocaust Survivors. Jerusalem: Keter. (In Hebrew)

Yablonka, Hana. 2001. The Eichmann Trial and the Israelis: Forty Years After. Beshviley Hazikaron 41: $24-41$. (In Hebrew)

Yaoz, Hana. 1980. Hebrew Holocaust Fiction as Historical and Trans-historical. Tel Aviv: Eked. (In Hebrew)

Yehuda, Rachel, James Schmeidler, Milton Wainberg, Karen Binder-Brynes, and Tamar Duvdevani. 1998. Vulnerability to Post-Traumatic Stress Disorder in Adult Offspring of Holocaust Survivors. American Journal Psychiatry 155: 1163-72. [CrossRef] [PubMed] 


\title{
Essay \\ Fighting Law Enforcement Brutality While Living with Trauma in a World of Impunity
}

\author{
Roberto Rodriguez \\ Department of Mexican American \& Raza Studies, University of Arizona, Tucson, AZ 85721, USA; \\ rodrigu7@email.arizona.edu; Tel.: +1-520-271-6796
}

Received: 30 October 2018; Accepted: 4 December 2018; Published: 15 December 2018

\begin{abstract}
By all rights, I should be dead. Not once, but a number of times. On 23 March 1979, as a 24-year-old, I witnessed and photographed the brutal beating of a young man in a sarape by some 10-12 Sheriff's deputies on Whittier Blvd in East Los Angeles. In turn, the deputies turned on me with their riot sticks cracked my skull, and sent me to the hospital, charging me with attempting to kill 4 of the deputies. On my arrest report, it stated that I was the leader of a gang of 10-15 Mexicans. With active death threats from the original Sheriff's deputies that drove me to the jail ward of the LA County Hospital, I was subsequently arrested/detained some 60 additional times, primarily by Sheriff's deputies and LAPD officers. By the end of the year, the criminal charges were dropped and 6 years after that, I emerged victorious in a lawsuit. That was a generation ago. No. That was at least two generations ago. I healed long ago from PTSD, though the brutality I witnessed and lived continues to reside within me, intergenerationally. This defies explanation. I am healed, yet the trauma continues to live within my body, even some 40 years after the fact. My life thereafter has been dedicated to the elimination not only of this brutality, but also a trauma that I can literally trace to 1492 on this continent through my studies on this topic. How do the Red-Black-Brown communities of this nation heal when that brutality and that memory have always been present intergenerationally and are not going away anytime soon? I want to explore the tension between fighting for the elimination of law enforcement abuse and living with that intergenerational trauma. The subtext of [anti-indigenous] racial profiling as used against Mexicans in this society, from police to immigration agents to the media, will be examined in this first-person article. How the survivors of this brutality and their families, who have lost loved ones and who fight against this brutality live with these traumas-particularly with the knowledge that as a result of impunity, there is no end in sight to this brutality-will also be examined.
\end{abstract}

Keywords: law enforcement violence; living with trauma; impunity

By all rights, I should be dead. Not once, but a number of times. On 23 March 1979, as a 24-year-old, I witnessed and photographed the brutal beating of a young man by some 10-12 Los Angeles County Sheriff's deputies, wearing a sarape on Whittier Blvd in East Los Angeles. In turn, the deputies turned on me with their riot sticks, cracked my skull and sent me to the hospital, charging me with attempting to kill 4 of the deputies. While this may sound surreal, it was not; it was very real and actually not unique. In communities of color, when one gets brutalized, the person brutalized often finds themselves charged with assaulting said officers and generally sent to jail or prison.

On my arrest report, it stated that I was the leader of a gang of 10-15 Mexicans. With active death threats from the original Sheriff's deputies that drove me to the jail ward of the LA County Hospital, I was subsequently arrested/detained some 60 additional times, primarily by Sheriff's deputies and LAPD officers. By the end of the year, the charges were dropped and 6 years after that, I emerged victorious in a lawsuit. The deputies never faced a criminal trial for nearly killing me. That was a generation ago. No. That was at least two generations ago. I healed long ago from Post-Traumatic 
Stress Disorder (PTSD), though the brutality I witnessed and lived through continues to reside within me, permanently etched into my psyche, intergenerationally. This defies logic or explanation. I am healed from PTSD and TBI (Traumatic Brain Injury), yet the trauma continues to also live within my body, even some 40 years after the fact. If I needed a reminder, I still have a scar between my eyes where my skull was fractured. Forgetting this trauma is not an option; it is there every time I face a mirror.

Regardless, my life after that incident has been dedicated to the elimination not only of this brutality, but also to attempt to eliminate a collective trauma that through my studies on this topic, I can literally trace to 1492 on this continent. How do the Red, Black and Brown communities of this nation heal when that brutality and that memory has been present some 500 years and is not going away anytime soon?

There is a tension within me between fighting for the elimination of law enforcement abuse and living with that intergenerational trauma. The backstory or subtext of racial profiling used against Mexicans in this society, from police to immigration agents to the media, is really about the unfinished business of Manifest Destiny. That profile, not incidentally, is Indigenous; the profile is brown (including the use of the Spanish language) and that which also connotes difference and not belonging. I know it deep within my bones and I know its effects, both from my own lived experience and from knowing and meeting other Red, Black, and Brown survivors and the families of victims of this brutality, who have lost loved ones. These are the families that fight daily against this brutality and who to this day live with these traumas with the full knowledge that as a result of impunity, there is no end in sight to this brutality. For me, even to this day, that trauma and memory are also embedded in my skin. I will not explain further.

What happened to Rodney King in Los Angeles was a generation ago. What happened to me was two generations ago. I was 24 at the time, and I feel as though my youth was robbed from me. In a way, my mind had already been that way since at least 1970, because that was when Los Angeles Times journalist Ruben Salazar was killed by East LA Sheriff's deputies in the aftermath of a very violent police riot in East LA (Morales 1972), literally down the street from where I grew up. Of course, it had a tremendous impact on all those of my generation. I had actually even witnessed a similar kind of violence a couple of years before that, during the East LA walkouts of 1968 (García and Castro 2011). That was the first time I had seen police attack Mexican/Chicano youths en masse. But one thing is to see it on television, another thing is to live it. Through the years, people have intimated that I am insane as a result of what I have lived, but really, it is our society that is insane, because it has always tolerated this violence via a compliant judicial system and a body politic that permits it.

Ever since the late 1960s and then the late 1970s, when I was almost killed, I have been keenly aware of the brutality used against people of color, and in particular the Red, Black and Brown peoples of this nation. It is not a pretty picture and it is a story of impunity. The knowledge and memory of that impunity survives in our DNA. I remember after I was almost killed, I began to look back to find out when things were better. Thus I examined the '70s, the '60s, the ' 50 s (Bloody Christmas in LA, as depicted in the opening scene of the movie, LA Confidential) on through the 40s and the Zoot Suit Riots of 1943 (as depicted in Valdez 1982). All of these decades had been very violent relative to communities of color. But when I reached the 1930s, on top of the brutality that was occurring in our nation's barrios, ghettos and reservations, there was a history of lynchings in this country. Most people barely know about lynchings in the Black community, and they know next to nothing about the lynchings against Native peoples, Mexican peoples and Chinese peoples. The lynchings against the Black community began in the 1880s, but the lynchings against Mexicans began shortly after the conclusion of the war against Mexico, after 1848. However, to be truthful, what happened to the Native communities of this country and continent is something far beyond lynchings. It is not an exaggeration; it involved genocide, land theft, and slavery, on top of legalized segregation and discrimination. This history is complex, but in the end, it can really be explained by the concept of dehumanization. When Europeans first arrived on this continent, they in effect came with the idea that 
the people here were less than human. At best, the peoples here were viewed as people whose souls could be saved for the Catholic Church. Here there is no room to detail all the brutality, all the violence that was inflicted upon Native peoples on the entire continent. Suffice it to say that if things were good today, perhaps no one would care about the past. However, that is the problem; the violence that began in 1492 has never been righted. Rather than condemn that genocide, there is a common view that we indeed have finally become somewhat civilized. Prior to this administration that was no longer a doubt, but it appears that those blatant attitudes have returned to those of the colonial era. What has never happened is a complete denunciation of their missionary efforts, nor have the responsible parties (The Catholic Church, Spain, and several other colonial powers) ever apologized for their genocide, land theft, enslavement, and reign of terror. The truth is, there never was anything wrong with us. And yet to this day American and Euro-centered history books treat my/our ancestors as though they were demonic, until they were saved by these interloping men of the cloth from across the ocean.

Some people think that my views are harsh, colored by the violence I have lived, although really they are not harsh at all. If anything, because that violence lives within me, it simply keeps me keenly aware of the violence committed against our communities/ peoples, who were then blamed for that violence against them. This is true whether it was 1492 or 2018.

If I were sane, I would never broach this topic ever again. However, the fact is that at the behest of a publisher, I actually recently wrote a book (Rodriguez 2019) on violence; a memoir and an examination of the recent violence against communities of color. I probably should not have written it. It was not healthy; in fact, it was very unhealthy for me to have done so. I not only recounted my own life in relationship to the violence I was subjected to when I was younger, but I also examined thousands of law enforcement killings since Michael Brown was killed in Ferguson, Missouri. Part of doing that also meant watching many videos of gruesome killings, though almost all were ruled "justifiable." They always are. Even with the existence of graphic videos. One other thing that I did is connect these killings with the thousands of murdered and missing indigenous and migrant women in this country. The nexus is the judicial system that rarely investigates or prosecutes and devalues them as less than human. The nexus is the politicians that remain silent and that also profit from the related prison-industrial complex.

Truthfully, I am not sure why I am writing this. It takes me to a very dark place. As I noted, this topic is very unhealthy for me. However, perhaps that is the point. It is not that it is uniquely unhealthy for me per se, but rather, it is very unhealthy for humanity and in particular, Red, Black and Brown peoples. It is unhealthy because many of us are killed, while others are brutalized and permanently injured for life, either physically or psychologically. Some of us are incarcerated. Many of us live the rest of our lives untreated. For us it is a pandemic. The pandemic is the violence inflicted upon us by law enforcement officers, compounded by the fact that many youngsters grow up with untreated injuries. This in turn creates collateral damage against those closest to us, which include family, spouses, neighbors, and friends, and worse, against themselves.

I have always posed this question: when a kid picks up a gun and goes across town to shoot someone else, knowing full well that they could be killed in the process, is that youngster exhibiting homicidal or suicidal behavior? My response: genocidal behavior.

Truly, it sounds like a tangential issue, but it is not. Our communities and peoples have a collective memory and that is what is referred to as historical or intergenerational trauma. While criminologists or political scientists may come to conclusions about the effect of violence in our communities, our communities already know those consequences. We have lived this violence, generation upon generation, always with impunity.

So yes, many of us already know these things, and thus the question remains: why am I writing about this, knowing full well that this is not healthy for me? I had to think long and hard about this, and yet the answer is easy. In the past several years I have done intense research about all those killings since Michael Brown. There have been some 5000, on average between 1100-1200 per year. 
One thing is certain, only a few dozen cases have been given national attention and those few are primarily young Black men who have been killed by police. That means that the other 4950 cases are virtually unknown to the majority of people in this country. That means that the majority of Black cases are unknown. In a similar way, very few people know about the Red and Brown peoples that have been killed in that same time period. Perhaps only statisticians are aware of this, but per a special report in In These Times: "The police killings no one is talking about" (Stoddard 2016), American Indians are the peoples most likely to be killed by law enforcement in this country. Brown peoples (in this country, that primarily means Mexican and also Central American peoples, most of whom are de-indigenized indigenous peoples), are also being killed at incredible rates, though completely off the radar. The killings of Brown peoples are not only not being reported in the media, but they are always greatly undercounted and miscounted. In my research, I estimate that they are undercounted by at least one third and possibly more. Due to this statistical anomaly, in 2018, for instance, as per an analysis of the Washington Post's Fatal Force Report (Wshington post 2018), about the same amount of Brown peoples are being killed as Black peoples. The reason these numbers do not show up that way is that most Brown peoples are placed into the Hispanic or Latino categories and "can be of any race," thus resulting in finding many last names such as Garcia and Lopez in all the racial categories, but especially in the unknown and White categories. I have always believed that the Hispanic category is both an invented category, but also a denigrating category because it assigns a colonial designation to essentially indigenous peoples that were colonized by European (Spanish) colonists. What this translates to is psychic or colonial violence of misnaming, resulting in "de-indigenization," which becomes a form of intergenerational trauma.

I generally avoid the term historical trauma only because it implies that this violence is in the past. Intergenerational trauma is indeed a more proper term because it includes violence from the past but continues and lives with us not simply in memory but in the present. The official violence against Red, Black and Brown peoples in this country is akin to war crimes and does amount to crimes against humanity, particularly because of the impunity involved. Because of my own experiences, I do not believe in the judicial system of this country; I do not believe it is a place of justice. Neither do I believe in reforms and attempts to fix this system. It is not fixable. Of those 5000 people killed since Michael Brown, many were filmed and yet even with cameras and YouTube, these killings have not led to more convictions or any form of accountability. More importantly, these killings have not ceased. At the time of writing, less than a handful of officers involved in those 5000 killings have been prosecuted and convicted and are doing serious prison time. It is a virtual guarantee that in short order, even those few serving time will not serve out their complete sentences. Therein lies the answer as to why I chose to write this.

When these numbers are examined, no advanced country in the world comes even close to the numbers that we are seeing in this country, which includes some 1000 "Latinos" (Brown peoples) since 2014. Part of the reason for this is that this brutality and violence in this country are methods of control.

To characterize this as racism is not accurate enough. At the beginning, I noted the concept of dehumanization. That literally comes from 1492. If one examines that history of dehumanization one will note the same idea continues to exist in 2018. Otherwise, Whites in this country would also be killed in the same proportions. However, proportionately, the higher rate of killings per the Washington Post's Fatal Force report belong to the Red, Black and Brown peoples of this country. Every single unjustified use of force against White people is also tragic. The primary difference is that when it comes to Red, Black and Brown peoples, our bodies and communities are patrolled. With Whites, one could say that their killings are random. Both kinds of killings are inexcusable, though at least what can be seen is that there is a different kind of patrolling when it comes to communities of color.

I have noted that I do not believe in the U.S. judicial system. In the past, people have gone to the UN and denounced the United States and the UN has affirmed that we have a racist judicial system (Sheriff 2015). Personally, that does not impress me. That is, it is not enough to state the obvious: that we live in a racialized society. 
What I would love to see is a consolidation of cases taken before the international criminal courts of the UN and the (OAS) Organization of American States.

I am not naive and yet I believe this is the course of action that is necessary because all other avenues have been exhausted. Even if there were to be victories, the U.S. has a tradition of ignoring decisions from the international courts. Still, I believe that such an effort is necessary. Such trials are necessary because it is important for the psyche of our communities. It is a common belief that one day such injustices will be righted and that one day there will actually be a system of justice in place, if not in this country, at least internationally. No doubt many people probably believe that this is foolhardy. And perhaps some people would view this in the same manner as a political version of the Ghost Dance; the belief that things will be right on this continent once again. However, it is actually not that. Or perhaps not exactly that, but similar to the belief that we are not going away, we will always be here, and one day there will in fact be justice in this country.

I have spoken to many people over the years who think that the trauma within me is not healthy and that I should just forgive the deputies that almost killed me, if not for their benefit, for mine. I agree. However, my response has always been that I would be more than happy to forgive those that almost killed me-in prison. I say that because there is no substitute for justice. It is justice that heals.

The day justice arrives on this continent is the day that intergenerational trauma will cease to exist.

In regard to me almost dying, I actually did die, but I summoned myself back. That is what a Yolqui warrior is; a warrior that lives in the spirit world and is summoned to fight in this world. In this case, it was I who summoned myself back.

Rodriguez, the author of Our Sacred Maíz is our Mother, is an associate professor in Mexican American Studies at the University of Arizona. His Yolqui book is scheduled for publication in the fall of 2019.

Funding: This research received no external funding.

Conflicts of Interest: The author declares no conflict of interest.

\section{References}

García, T. Mario, and Sal Castro. 2011. Blowout! Sal Castro and the Chicano Struggle for Educational Justice. Chapel Hill: The University of North Carolina Press.

Morales, Armando. 1972. Ando sangrando (I am bleeding): A Study of Mexican American-Police Conflict. La Puente: Perspectiva Publications.

Rodriguez, Roberto. 2019. Yolqui. Tucson: University of Arizona Press.

Sheriff, Natasja. 2015. US Cited for Police Violence, Racism in Scathing UN Review on Human Rights. Available online: http:/ / america.aljazeera.com/articles/2015/5/11/us-faces-scathing-un-review-on-human-rightsrecord.html (accessed on 14 December 2018).

Stoddard, S. 2016. The police killings no one is talking about. In These Times, October 17.

Wshington post. 2018. 957 People have been Shot and Killed by Police in 2018. Available online: https: / /www.washingtonpost.com/graphics/2018/national/police-shootings-2018/?noredirect= on\&utm_term $=.419947$ cd5242 (accessed on 14 December 2018).

Zoot Suit. 1982. Directed by Luis Valdez. Universal City: Universal Pictures.

(c) 2018 by the author. Licensee MDPI, Basel, Switzerland. This article is an open access article distributed under the terms and conditions of the Creative Commons Attribution (CC BY) license (http:/ / creativecommons.org/licenses/by/4.0/). 



\title{
Essay \\ Why the Armenian Genocide Lives in Me
}

\author{
Barbara Erysian \\ Department of Mathematics, Sierra College, Rocklin, CA 95677, USA; berysian@sierracollege.edu \\ Received: 6 September 2018; Accepted: 14 November 2018; Published: 21 November 2018
}

\begin{abstract}
Little has been taught about the Armenian Genocide of 1915 when approximately 1.5 million Armenians were brutally slaughtered. Moreover, the events are still being denied today. Community College Math Professor Barbara Erysian, an unlikely candidate to tell the story, carries the memories and sorrow of her people. She has dedicated herself to telling the story of how her grandmother survived the genocide. The story, repeatedly told to her as a child, is very much a part of her identity. Her essay describes some of the terrors of 1915. She believes the memory and pain of the Armenian Genocide must be told so that these crimes are never forgotten.
\end{abstract}

Keywords: Armenian; genocide; 1915; human rights violation; Christianity; Holocaust

I remember her vividly. She was a tiny woman who could look me straight into the eyes. I imagine that she stood about 5 feet tall. She had waist long silver hair. As a child, I would watch in amazement each morning as she would braid and then carefully twist and turn and pin her hair into a neat bun on the top of her head. She loved to cook Armenian food and everyone loved to eat it. Throughout the day, I could often hear her say, "thank you Jesus."

But it was not her hair or her sayings that became part of me. It was the story that she repeated so often ... so clearly and so passionately. Every day I visited her, and several times a day after she got Alzheimer's, she would tell me how she survived the Armenian Genocide. Since I was only a child, I could not really understand what she was saying or how it could have been possible. How could such terrible things have happened to this petite, loving woman that I called "Grandma Alice"?

The treacherous story with the unexpected ending was always the same. Her father was taken in the dead of the night. All she knew about what happened to him was that he was buried alive in the desert. I later determined this would have been the Syrian Desert because that is where approximately 1.5 million Armenians would have died after being forced to march in the hot, burning sun with no food or water. She would then tell me how she and her little brother were taken to an orphanage. She would have been 14-years-old and her brother would have been 6-years-old in 1915.

I always wondered why she never mentioned what happened to her mother. Didn't she know? Or, why wouldn't she tell me? When the Turkish Government issued an order to kill every Armenian, young or old, without mercy - they did worse. I believe that what was done to her mother was so horrific that she would not or could not find the words to tell me. I believe that my great grandmother was possibly raped or sliced or burned or hung or poisoned or drowned or any combination of these or worse. During those days, the Armenians were shown no mercy. My grandmother witnessed a baby being sliced from its mother's womb and hot oil being poured down a man's throat. And the stories of wide scale torture and slaughter are Barbaric and horrific. The accounts of diplomats in the region pleading for help went unanswered. The letters from Armenians seeking help and relief are so fraught with sorrow that one must turn away. The murderous rampage was nothing short of barbarism and this massacre set a precedent for the Jewish Holocaust in the 1930's.

In the orphanage, my grandmother and her brother nearly starved to death. Her assigned job was to wash the dead bodies. And, after the work was done she could eat. The bread was made out of corn cobs. What she did tell me was that after every meal she would walk the entire length 
of every table. She would start with only one bread crumb. And from there, she would gather two and then three crumbs and soon she would have a wad of dough. She would feed this small wad of dough to her young brother "to keep him alive." When telling me the story, she would then place imaginary wad dough into my hand and implore me, "Tell your children. Tell your children's children ... Never forget."

I have lived with this story for forty years. As a child, I did not truly understand what she had experienced. I did not learn to speak Armenian unless one considers counting to ten. I learned to cook a few Armenian dishes and wore a traditional Armenian dress to a junior high school function. When my children were in elementary school, I encouraged them to do projects on Armenia. And so, they did Armenian cooking projects (Baklava—of course) and costume projects and music projects.

But five years ago, as I was watching the television, it seemed as though I was watching the story unfold again. Isis was slaughtering the infidels in the Middle East-needlessly, ferociously, viciously and in a barbaric fashion once again ... just like 100 years ago. I began researching the Armenian Genocide and discovered that not only were Armenians slaughtered but also Greeks, Assyrians, Jews, Atheists, and anyone else who was non-Muslim. They were drowned in the Black Sea, buried alive in the Syrian Desert and slaughtered everywhere in-between. Could it be that history was repeating itself?

As I watched the tragic stories unfold on television, I realized that I had carried this story inside myself for 40 years. It was as much a part of me as her. As she placed that wad of dough into my hand she placed not only the story, but the memories of the suffering, of the pain and of the injustice. She had laid her story upon my heart and I took it upon myself to tell not only her story but the story of the Armenian people that were needlessly slaughtered in 1915. I contemplated writing a book but soon realized that in order to reach the widest possible audience I would need to make a movie. As naïve as that sounds I set out on this passion project. I began researching how to write a screenplay and five years later, I've created a short film paying homage to my grandmother in hopes that someday I will make a feature film akin to Schlinder's List. My goal is to make a film that everyone will see and discuss and learn from so that the Armenian Genocide will not be buried in the history books nor be allowed to be denied.

Researching the Armenian Genocide over the past several years has taught me several things. First, that the wounds are still very real and very painful for the Armenian people. Every 24 April, Genocide Day is recognized throughout Armenian communities all over the world. This is a day that Armenians gather to grieve and remember the horrible events of the past. The commemorators around the world join together to pray, sing, dance, and speak about the massacre of their ancestors. The tears and passion lives on in the lives and hearts of the children and grandchildren.

Secondly, I learned that during the genocide there were ambassadors and missionaries and diplomats in Armenia who were pleading for help. Many, many articles were published in the New York Times giving accounts of the horrific events in Armenia. But, the desperate cries for help, assistance and relief were answered with silence.

For some Armenians, the pain is so deep they cannot talk about it. The stories they have heard lives deep within them and will be passed to their children in deep and subtle ways. It is not only what one speaks about that is transferred but also the silence. One of the worst parts of the Armenian Genocide, that I believe prevents any real healing, is that the current Turkish Government fails to take responsibility for these events. The fact that the Armenian Genocide is vehemently denied by those who know what happened continues to perpetrate the pain and suffering.

The dedication on my film reads, "To my Grandmother Alice and all those who perished and all those who survived." In creating the movie and connecting with other Armenians, I realized that the pain we feel is deep.

The title of my film, "Who Will Remember", is taken from the quote from Adolf Hitler who stated, "Who will remember the annihilation of the Armenians?" He spoke these haunting words prior to invading Poland and slaughtering thousands of Jews. It is my hope and prayer that WE WILL REMEMBER. I believe that we must. 
Funding: This research received no external funding.

Conflicts of Interest: The author declares no conflicts of interest.

(C) 2018 by the author. Licensee MDPI, Basel, Switzerland. This article is an open access article distributed under the terms and conditions of the Creative Commons Attribution (CC BY) license (http:// creativecommons.org/licenses/by/4.0/). 

MDPI

St. Alban-Anlage 66

4052 Basel

Switzerland

Tel. +41616837734

Fax +41 613028918

www.mdpi.com

Genealogy Editorial Office

E-mail: genealogy@mdpi.com www.mdpi.com/journal/genealogy

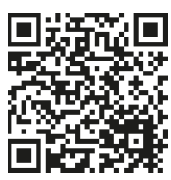



MDPI

St. Alban-Anlage 66

4052 Basel

Switzerland

Tel: +41 616837734

Fax: +41 613028918

www.mdpi.com 